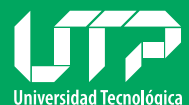

Universidad Tecnológica de Pereira

Facultad de Ciencias de la Educación

\title{
De ver pasar
}

Rigoberto Gil Montoya

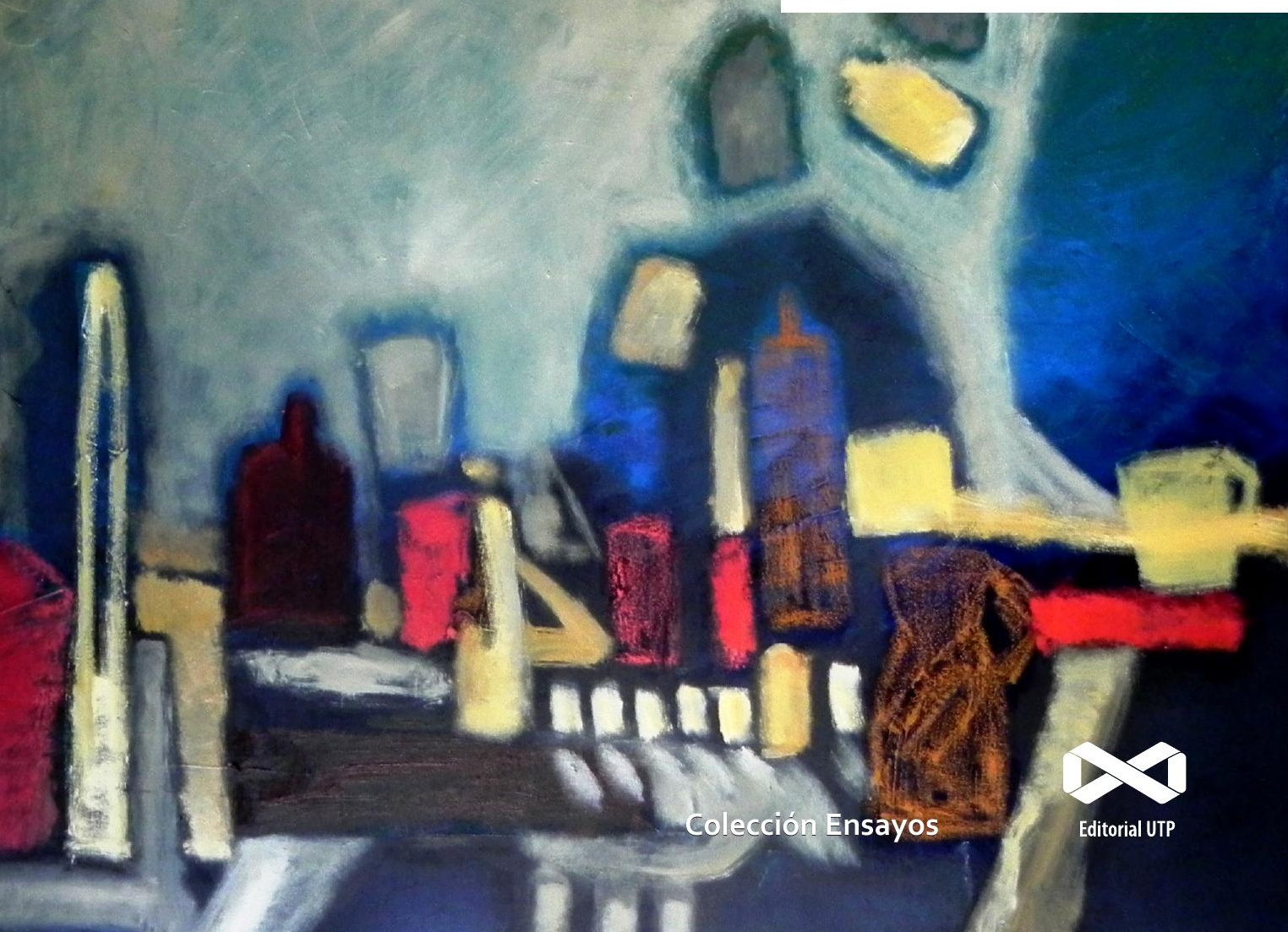




\section{Rigoberto Gil Montoya}

La Celia, Risaralda, Colombia, 1966. Es narrador y ensayista. Se doctoró en Literatura en la UNAM. Profesor titular de la Escuela de Literatura y Lengua castellana, Facultad de Educación, de la Universidad Tecnológica de Pereira. Docente del Doctorado en Literatura y de las maestrías en Literatura y en Estética y Creación. Dirige el grupo de investigación Estudios Regionales sobre Literatura y Cultura.

Entre sus libros publicados se destacan El laberinto de las secretas angustias (1992), La urbanidad de las especies (1996), Perros de paja (2000), Plop (2004) y La buena hora de la literatura colombiana en el siglo XX (2019). Ganador del concurso de ensayo "Caldas 100 años" con su libro Guía del paseante. Premio Nacional de Literatura 2014 de la Universidad de Antioquia, con su obra Mi unicornio azul. Obtuvo el segundo lugar en el III Concurso de Novela Corta de la Universidad Javeriana, con El museo de la calle Donceles. En 2017 obtuvo el Premio Nacional de Periodismo Simón Bolívar, modalidad de Crítica.

Contacto: rigoroso@utp.edu.co 
De ver pasar 

De ver pasar

Rigoberto Gil Montoya

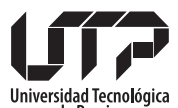

de Pereira

Facultad de Ciencias de la Educación

Colección Ensayos

2020 
Gil Montoya, Rigoberto

De ver pasar / Rigoberto Gil Montoya - 1a ed. -- Pereira : Universidad

Tecnológica de Pereira, 2020.

232 páginas : ilustrado. - (Colección Ensayos).

ISBN: 978-958-722-474-0

1. Ensayos - Colombia 2. Guerra civil - Colombia 3. Narcotráfico - Colombia 4. Estudiantes universitarios - Colombia 5. Seguridad - Colombia 6. Democracia Colombia 7. Fotografía - Vida cotidiana - Colombia

CDD. 863.6

(C) De ver pasar

(c) Rigoberto Gil Montoya

(C) Universidad Tecnológica de Pereira, Vicerrectoría de Investigaciones, Innovación y Extensión

(C) Editorial Universidad Tecnológica de Pereira

Primera edición, 2020

Libro ganador de la Convocatoria 2020,

Modalidad Ensayo

elSBN: 978-958-722-475-7

ISBN: 978-958-722-474-0

Vicerrectoría de Investigaciones, Innovación y Extensión Editorial

Universidad Tecnológica de Pereira Pereira, Colombia

Coordinador editorial: Luis Miguel Vargas Valencia

luismvargas@utp.edu.co

Teléfono (6) 3137381

Edificio 9, Biblioteca Central "Jorge Roa Martínez"

Cra. 27 No. 10-02 Los Álamos, Pereira, Colombia

www.utp.edu.co

Portada: Ciudad gaseosa (2014), de la artista Viviana Ángel. Colección Juan Nicolas Gaviria

Diseño y diagramación: Margarita Calle

Impresión y acabados

Gráficas Olímpica, Pereira

Reservados todos los derechos 


\section{Gratitudes}

A mi amigo Gustavo Colorado, sabio en el arte de anudar senderos y trochas con el trazado ancestral del Camino del Quindío. A él debo que buena parte de las páginas de De ver pasar fueran publicadas en el portal La cebra que habla, con la complicidad de su directora Martha Alzate.

A Mauricio Gómez, Magosa. La dinámica de escribir un texto breve partiendo de una imagen fotográfica surgió en las páginas de Ciudad cultural (2012-2016), del Instituto Municipal de Cultura y Fomento al Turismo y la Corporación Ciudad Latente.

A la Vicerrectoría de Investigaciones, Innovación y Extensión de la Universidad Tecnológica de Pereira, por apoyar y difundir la labor intelectual de sus profesores. 



\section{Inventario}

Un apunte necesario $\quad 11$

$\begin{array}{ll}\text { El ojo que piensa } & 13\end{array}$

La prótesis de la guerra $\quad 21$

$\begin{array}{ll}\text { Milagro en la calle } & 27\end{array}$

Más colombiano que nunca $\quad 31$

Trabajo con altura $\quad 35$

Derecho a dormir dignamente $\quad 39$

Lo positivo: preguntar por la verdad $\quad 45$

Un país de sabios $\quad 51$

El sueño de Greta Thunberg $\quad 57$

El Niño Dios $\quad 63$

La economía naranja $\quad 69$

$\begin{array}{ll}\text { Arde el planeta } & 77\end{array}$

Mataculebras $\quad 81$

$\begin{array}{ll}\text { Perorata de un perro vallejiano } & 87\end{array}$

$\begin{array}{ll}\text { Favor no tocar } & 93\end{array}$ 
Dilan

Popeye el sicario soy

103

Cuando las monjas hablan

Bulevar de los héroes

Covid-19

Instrucciones para soportar el miedo

Postales anómalas

El paga diario

Diálogo con Oscar Wilde

Enseres para sobrevivir en casa

El replicante

La muerte y sus caracteres

Huellas de lectura

Brazos caídos, vidrios rotos

183

Preguntas de oficio

El culo

El placer de leer

Vidas inusuales. La casa de los hermanos Collyer

El mal gusto

La sombra del Poder

Desaparecer

Qué raro que me llame Rigo 


\section{Un apunte necesario}

Antes de que De ver pasar desembocara en este libro, primero fue un ejercicio de escritura que se impuso como memoria de un devenir en forma de breves ensayos. Cada uno de ellos aspira a traducir la composición de una imagen fotográfica, tomada a la sombra de ese vaivén que nos obliga a bajar escaleras de granito y a cambiar de acera cuando el sol quema la piel. Su interés creció con el tiempo de la contingencia sanitaria, causada por la pandemia del COVID-19. Se pretendió hacer un registro de lo que nos estaba pasando, de ese tiempo lento, inesperado y enigmático; de esa orden ambigua de «Quédate en casa». Por eso estas páginas se publicaron en el portal La cebra que habla, como esa inscripción que quiere permanecer en el intervalo de la huella y el testimonio. 
Ahora que este ejercicio de escritura se recoge a manera de libro, sospecho que los textos seleccionados no han perdido del todo su carácter inédito. Algo nuevo arroja su unidad, el orden de su inventario. Espero que despierte alguna emoción en el lector que sigue viviendo un tiempo lento en el que lo inesperado y enigmático, arroja signos que conviene discernir. 


\section{El ojo que piensa}

Ni siquiera puedo refugiarme en esa zona de bordes indefinidos que es el ensayo.

Alejandro Rossi, Cartas credenciales

No es fácil caminar y pensar al mismo tiempo. El cuerpo se fatiga si lo obligamos a concentrarse en dos ejercicios complejos. Ambos exigen voluntad, concentración; ambos validan un ritmo arcano que se liga con la memoria: ese fardo de realidades que teje los años en imágenes delgadas. Solo que, al restaurarlas, les damos volumen y profundidad. Algunos creerán que es nostalgia, 
[ 14 ] briznas de un espíritu romántico obstinado. Prefiero ser práctico: es una forma de respirar, de asignarle a nuestras huellas un horizonte que palpita.

El corazón y el cerebro se conectan con la circulación sanguínea; se produce un estremecimiento inédito en el calcáneo, mientras en la zona que delimitan el astrágalo y el metatarso, percibes los pliegues de unas cosquillas infantiles y es como si el milagro de la vida sucediera en un segundo. Hablo de una revelación, de un leve temblor de sabernos vivos. No hay manera de explicar lo que se siente, porque todo es ingrávido y momentáneo a la vez, más allá de la lluvia, más allá del calor. Solo percibimos que, al caminar, al superar un obstáculo en la acera y al levantar la mirada hacia ninguna parte, sucede que observamos algo que jamás habíamos visto: el trazo rabioso de un grafiti en una loza de pedernal; la grieta con nervaduras en una fachada húmeda; el grosor del hollín en un semáforo intermitente; la forma provocadora en la que una mujer se reconoce, casi desnuda, en el reflejo de una vitrina. Te invade, sin embargo, la sospecha de que nada de lo que has visto es nuevo, que su materia onírica deviene tan familiar como tus tenis. Quizá en el fardo de tu memoria se hayan mezclado pedazos de imágenes en tono sepia, el fotograma de 
una película vista en un cine de barrio, la instantánea en colores tomada al azar un día después del sábado. ¿Será que el ojo piensa? Te cuestionas y una posible respuesta la encuentras cruzando la otra esquina, cuando te enteras que no estás solo, que otros caminan con una feliz insolencia parecida a la tuya; que apenas eres parte de una ciudad que te observa en el brillo de las cosas y te ofrece caminar y pensar al mismo tiempo.

Todo lo dicho hasta aquí pretende justificar un instante. Juzgo que era martes y que salí a caminar después de las cuatro de la tarde. Había un aire pegajoso, mezclado con partículas de polvo, como si la ciudad estuviera mudando de piel, agotada a esa hora en el núcleo de sus arterias transitadas. No recuerdo el rumbo ni el número de esquinas que había superado antes de llegar a una encrucijada de adoquines, donde un perro vagabundo orinaba tranquilo. Solo recuerdo el color del día, un par de árboles de guayacán sin flores y el ruido estridente de una ambulancia que conminaba a despejar la vía. Algo en mí detuvo los pasos y el corazón aceleró su cadencia. Las luces de la ambulancia trajeron a mi mente la imagen de un hombre que, al intentar cruzar la calle, había sido atropellado por una furgoneta. No era un flâneur despistado ni el anonimato su destino. Se llamaba Roland Barthes 
[ 16 ] y había sido atropellado en la Rue des Écoles, al borde de La Sorbonne, en uno de cuyos auditorios acababa de impartir una de sus lecciones de semiología. Era febrero de 1980. Semanas atrás Barthes había publicado La cámara lúcida y el mundo intelectual celebraba la rutilancia de su mirada. Dijo, como al descuido: «... las fotos son signos que no cuajan, que se cortan, como la leche (...) una foto es siempre invisible: no es a ella a quien vemos».

El invierno había opacado la luz de ese día. Para un hombre de sesenta y cinco años la borrosidad alojada en el afuera se distingue a cada paso. Trastabillar es moneda corriente. Acostumbrado a hurgar en la metafísica de los objetos, ese martes Roland Barthes se lanzó a la calle. Quizá vio la señal próxima al semáforo, pero olvidó interpretar los signos. Quizá andaba distraído, pensando en las manos tersas de su madre. El atropellado había enseñado a leer los signos de la cultura a varias generaciones y había sentenciado que «la modernidad comienza con la búsqueda de una Literatura imposible». Quiero pensar que fue uno de sus discípulos quien trasladó su cuerpo maltrecho a la sala de urgencias del Hospital Pitié-Salpêtrière. Un mes después de aquel descuido urbano, moriría. El semionauta dejó de tener signos vitales. 
Entonces comprendí lo que estaba pensando mientras caminaba. Pensaba en la literatura y en sus formas, en los peligros que acarrea bordear sus límites, en que uno puede terminar atropellado, bajo el signo de lo trágico. Pensaba en cómo responder a estos tiempos de la imagen y la palabra, en especial, cuando ambas no están blindadas, no habitan en ninguna torre de marfil y les toca enfrentar el caos de la cultura de masas. ¿La búsqueda de una Literatura imposible? ¿Por qué Barthes empleaba la mayúscula para designar una estructura del arte, una realización humana que se hace tan honda, digamos, en lo que Baudelaire en su Spleen de París (1869) no está muy seguro cómo definir y le da por declarar, como para atizar el problema, «... el milagro de una prosa poética, musical, sin ritmo y sin rima»? Poeta bohemio y sin aura, Baudelaire solía caminar a altas horas de la noche por las calles de París. De ver pasar es un ejercicio de escritura que quiere instalarse, con timidez néofita, en esa «Literatura imposible», que busca hacerse a un cuerpo en la contaminación de los géneros.

Lo imposible aquí es el equivalente de búsqueda, señal de exploración en la cartografía privada del hecho literario. No estoy solo en este intento, desde luego y lo hago después de admitir 
[ 18 ] el influjo de otras voces. Vila-Matas viene a mi auxilio: «Escribimos siempre después de otros». Con lo cual puedo reconocer, a modo de ilustración y sin rubor, unas deudas: Los autonautas de la cosmopista o un viaje atemporal París-Marsella (1983) de Julio Cortázar y su pareja Carol Dunlop; y El ojo de la cerradura (2006) de Juan José Millás. En ambas obras, las imágenes fotográficas hacen parte del significado, porque en ellas se origina un deseo, una pregunta. En ellas se condensa una realidad; allí se captura un fragmento de mundo, una composición urdida de signos. Aquello que cada imagen delata parece congelado, pero solo es aparente. Basta mirar la imagen con algún grado de interés y aspirar a traducir su encaje, para que toda ella se cargue de sentido, pues «... no es a ella a quien vemos». Lo que vemos está por fuera, en su contexto. Lo que vemos es la realidad de sus palabras, su trama convertida en argumento.

Las imágenes que acompañan cada texto de De ver pasar no son artísticas ni aspiran a serlo. Para ello habría que tener una «cámara lúcida» y un ojo que no solo piensa sino que además le es dado recortar y dirimir; fuera de saber nadar en eso que Cortázar en «Algunos aspectos del cuento» (1970) denomina como la 
«aparente paradoja». Esa virtud del fotógrafo artista capaz de encuadrar y acotar un pedazo de realidad mientras, en la obturación, implosiona otra realidad: «... como una visión dinámica que trasciende espiritualmente el campo abarcado por la cámara». Estoy lejos de arribar a esa paradoja aparente. Lo mío es más espontáneo, es decir, menos elaborado y más ingenuo; por eso pertenece al orden de lo cotidiano.

Aunque se expresa allí una temporalidad, algunos ejercicios de imagen-texto no escapan a lo casual ni a lo absurdo. ¿Quién iba a pensar que nos tocaría confinarnos, que debíamos quedarnos en casa si queríamos escapar a las garras invisibles del coronavirus? ¿Quién tenía entre sus planes detener su tiempo para admitir que hay un tiempo común para el miedo en todos los países? Algunos de mis textos recogen astillas de esa experiencia inaudita, más allá de la seguridad que brinda el cálido útero de nuestra casa.

Las imágenes fotográficas de De ver pasar han sido tomadas con mi celular, mientras caminaba por la urbe y mientras pensaba en el destino trágico de Roland Barthes. Pensar en la muerte, sobre todo en la muerte de seres esenciales, nos obliga a pensar en la propia muerte. Ahora bien, Barthes también nos enseñó a 
[ 20 ] entender esta paradoja en «La muerte del autor» (1968), en ese carácter polifónico y disuasivo que le permite al autor habitar en la voz de su narrador y en sus personajes. Tal vez este libro sea solo una nota al pie de página de alguien que lee, con recelo y pasmo, los signos de nuestro tiempo. 


\section{La prótesis de la guerra}

No conozco su nombre, solo reconozco la ausencia de sus pies. Debí mirarlo a la cara, ese acto tan humano de reconocernos en el otro, de saberlo próximo en sus gestos y arrugas; a lo mejor descubriría en sus tics alguno que me sea familiar. Solo se impuso en mi horizonte la contundencia de sus no-pies, el brillo metálico del aluminio o el acero inoxidable de un soporte artificial incrustado en unas botas militares, allá abajo, sobre la gravedad de la tierra, en un círculo del infierno del consumo. Leí que el cuerpo tiene memoria, de suerte que los no-pies seguirán unidos para siempre al nervio del cuerpo fragmentado. Una memoria dolorosa, que no olvida. Una memoria corporal, incompleta. En un acto reflejo miré mis pies calzados y me comparé con él, mientras hacíamos fila para pagar en la caja registradora. Ese hombre, pensé, está acos- 
Ty.n.

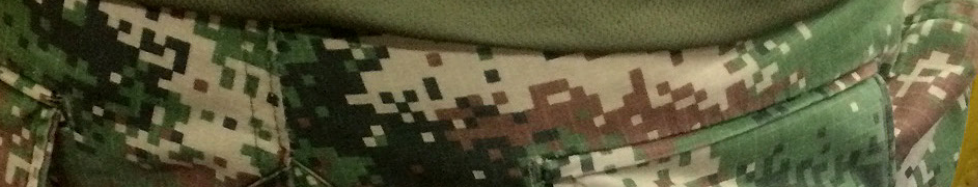

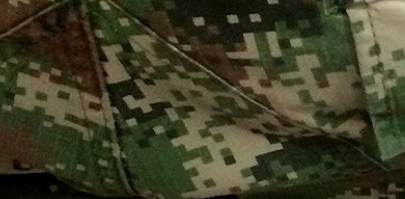

No

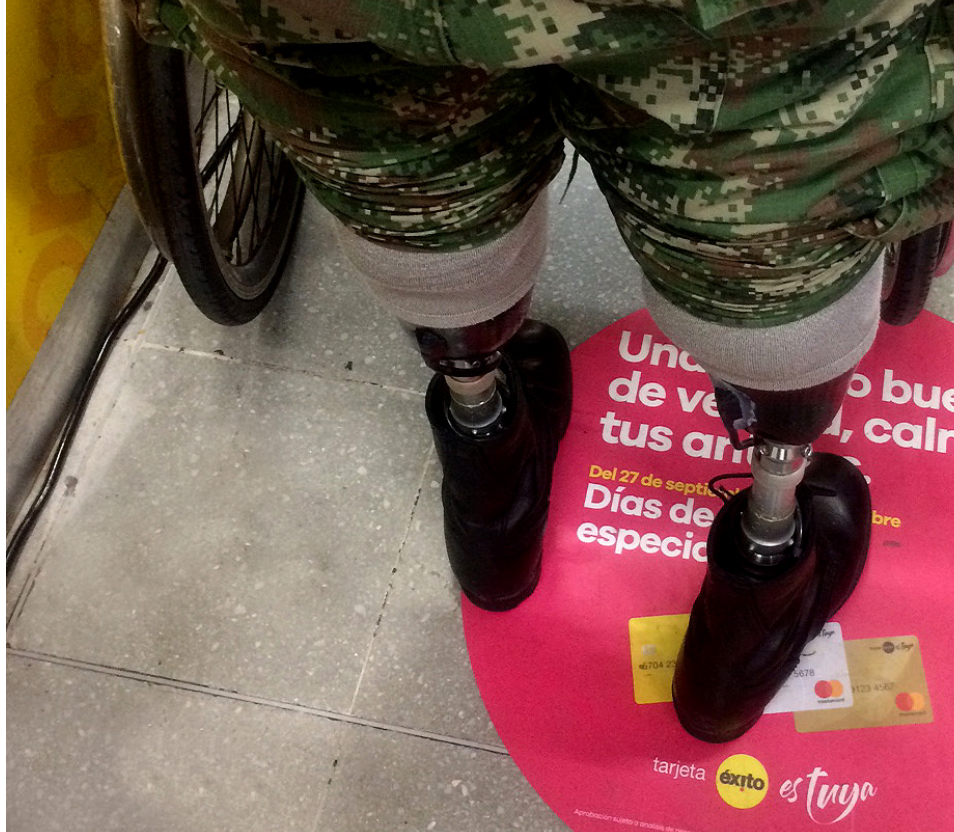


tumbrado a hacer filas: durante las madrugadas en los cuarteles, durante las tácticas en los campos de batalla, en la EPS donde buscará aliviar el dolor físico y moral con un analgésico, mientras espera a que el psicólogo lo anime con una ilusión: hay que seguir adelante, hacia otra fila. Para eso fue diseñada esa prótesis.

Este hombre porta un uniforme de uso privativo de las fuerzas militares. Se adapta en su cuerpo un pantalón camuflado. No es un pantalón cualquiera ni el hombre lo lleva puesto como alguien podría lucir un jean perforado. Es una tela especial que ni siquiera mi padre, sastre de profesión, podría ribetear. Es un pantalón hecho con alta tecnología, vanguardista y sus diseñadores le han dado forma teniendo en cuenta componentes ópticos y cerebrales, es decir, cómo vemos y de qué modo traducimos lo que vemos. Esto informan en la web de las Fuerzas Armadas. Obsérvese su pixelado, su textura de escamas. Parece la ampliación, a gran escala, de un código QR, bidimensional. Los colores se ajustan a los colores con que Alicia y Arturo Cova en La vorágine pintaron su delirio cauchero. Porque de eso se trata: de mimetizarse entre la manigua, de pasar inadvertido frente al enemigo y como en Apocalypse now, atacarlo por sorpresa, darle de baja. No es un Levi's, tampoco un Americanino, es algo más sofisticado: un 
[ 24 ] «patriota»; así se lo denomina, del mismo modo que a los fanáticos y nacionalistas. Quien vaya para la guerra puede escoger entre dos modelos: de selva y de desierto. Sabemos que en nuestro país el primero tiene mayor demanda.

De manera que este pantalón está hecho para cubrir el cuerpo de los llamados a la guerra. Este hombre ha vuelto de ella, imperfecto, disminuido, después de pisar una mina antipersonal y ha venido hasta acá, al supermercado, luego de enterarse, quizá por radio, que hace poco más de una semana dos niños de la zona rural de San Calixto, Norte de Santander, en circunstancias y espacios distintos, estuvieron a punto de perder sus vidas al pisar dos minas antipersonales sembradas, al parecer, por integrantes del ELN. Porque para estar en la guerra y ser víctima de ella, no es necesario vestir de camuflado y ser un patriota y dar la vida por su patria. Basta con vivir en las zonas de la guerra, como los niños santandereanos; basta salir a pasear el perro, salirse de una zona demarcada con plástico amarillo y volar en pedazos; o dejar pedazos de nuestro cuerpo en esas zonas rojas que algunos grupos políticos, obtusos, quieren reavivar. Nuestro hombre amputado está allí, en la fila, para advertir, sobre todo a los de la extrema 
derecha y de la extrema izquierda, que en la guerra se pierden cosas, incluso las extremidades.

Un general de apellido Giraldo, ecuánime él, aseveró que sus enemigos, los grupos guerrilleros, «se han desmadrado con el uso de las minas, pues ya no son para mutilar, sino para desaparecer un hombre». Pero es que este país, general, es un desmadre; aquí podemos desaparacer todos, porque la guerra es nuestra prótesis. La guerra, la continua, la variada, la que despedaza el cuerpo social, es nuestra prótesis de acero inoxidable. Hacia allá seguimos caminando. 



\section{Milagro en la calle}

¿Por qué una aparición, un milagro? Porque no sucede todos los días y cada día trae su propio afán. Puede que los domingos - como lo supo el poeta que parecía un caballo- amanezcamos lúbricos, lúbricos y pongamos la mano en el lugar adecuado. Tal vez el miércoles despertemos sórdidos, sórdidos, con el deseo de convertirnos en el lobo solitario de un colegio en recreo. A lo mejor el jueves nos sintamos plácidos, plácidos a eso de las tres de la tarde, cuando recibamos la llamada de un antiguo enemigo, derrotado. Pero quizá el milagro suceda al mediodía de un martes luminoso, ¡oh, tierra!, un martes en que discurren vientos ineluctables, un martes en que el milagro ya nadie lo puede detener. Como este que revela la imagen. 


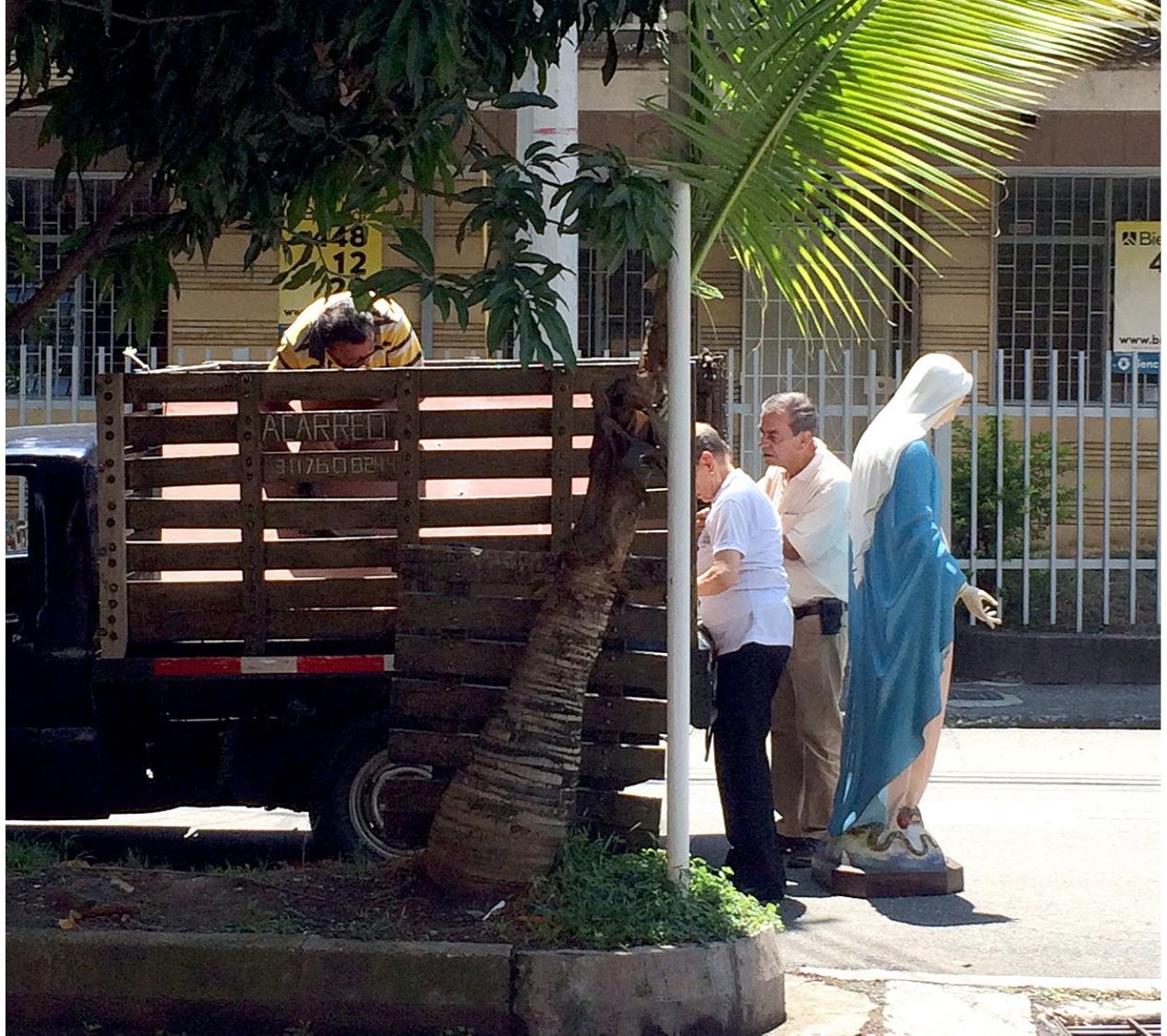


Todo sucedió de un modo inesperado, como es propio del milagro. Todo empezó en el momento en que esa pareja mayor decidió cambiar de casa. Querían una más pequeña y ubicada en otro barrio, ahora que sus hijos se habían ido. Es natural que se vayan, pensó ella, «Tal vez bajo otro cielo la Gloria nos sonría», dijo, enigmática, mientras le quitaba el polvo a la imagen venerada en su altar sagrado y él, su hombre, marcaba el 3117608244 . Necesitaban contratar un acarreo, trasladar unos bártulos, darle sentido a su vida de pareja en otro lugar. «¿Por qué hablas de bártulos?» Interrogó ella, fastidiada. «¿Qué es eso?»: «Pues enseres, mujer, cachivaches». Lo reprimió ella. «Nada de bártulos, llamemos a las cosas por su nombre. No necesitamos de bártulos ni de cachivaches. De aquí solo nos la llevaremos a ELLA», lo dijo con inusitada firmeza y en mayúscula sostenida. Él la miró perplejo; nunca le había respondido así: «ELLA proveerá lo demás. ¿No entiendes que la vida es clara, undívaga, y abierta como un mar?», recitó-interrogó, mientras se persignaba y hundía sus ojos en el horizonte azul en el que ELLA tomaba distancia de los mortales con sus ojos clavados en el piso. Perplejo, obnubilado por el acto sublime y rebelde de su dama, el hombre supo que lo mejor era guardar silencio. Esperar. 
[ 30 ] Ahora están allí, en la calle, cerca de un registro de alcantarilla. El hombre del acarreo llega puntual y es diligente. A la dama le preocupan los detalles del trasteo y por eso decide inspeccionar la camioneta, no sea que todo salga mal en este día, justo cuando «el alma está brotando florestas de ilusión». El hombre la vigila, quiere preguntarle algo, pero teme ser imprudente. Preocupados, sin embargo, por asuntos terrenales, la pareja le da la espalda al milagro. ELLA, imponente en su altura, parece encarnar un leve cambio. Observen la pose de su mano derecha. ¿No es un reclamo acaso, un por qué me descuidan y me rebajan a este nivel de la vida mundana? ELLA lo sabe todo y sabe que en la ciudad hasta ELLA puede ser robada, cambiada de altar. Casos se han visto. En breve el hombre pagará el acarreo «en rútiles monedas tasando el Bien y el Mal». El milagro se ha hecho humano en las afueras del capitalismo salvaje. 


\section{Más colombiano que nunca}

El escenario es un campo de batalla nada reciente: solo tiene doscientos años. Aquello que sí es reciente es esta puesta teatral y telenovelesca que busca enaltecer lo que la publicidad afirma: el avance por Colombia de unos «Héroes bicentenarios». Como toda publicidad, lleva implícitos mensajes subliminales, los de aquí me desconciertan. Para empezar, es inquietante que el Estado haya escogido los aeropuertos para promocionar la labor bélica, por poco turística de sus fuerzas militares. Esta que ven aquí está a un lado de las cintas transportadoras que le retornan al viajero su equipaje. Es un lugar estratégico, sin duda, porque mientras uno espera minutos a que aparezca su maleta, es imposible que el viajero no se percate de esta imagen impactante y que se haga partícipe de un escenario cinematográfico en conflicto. 


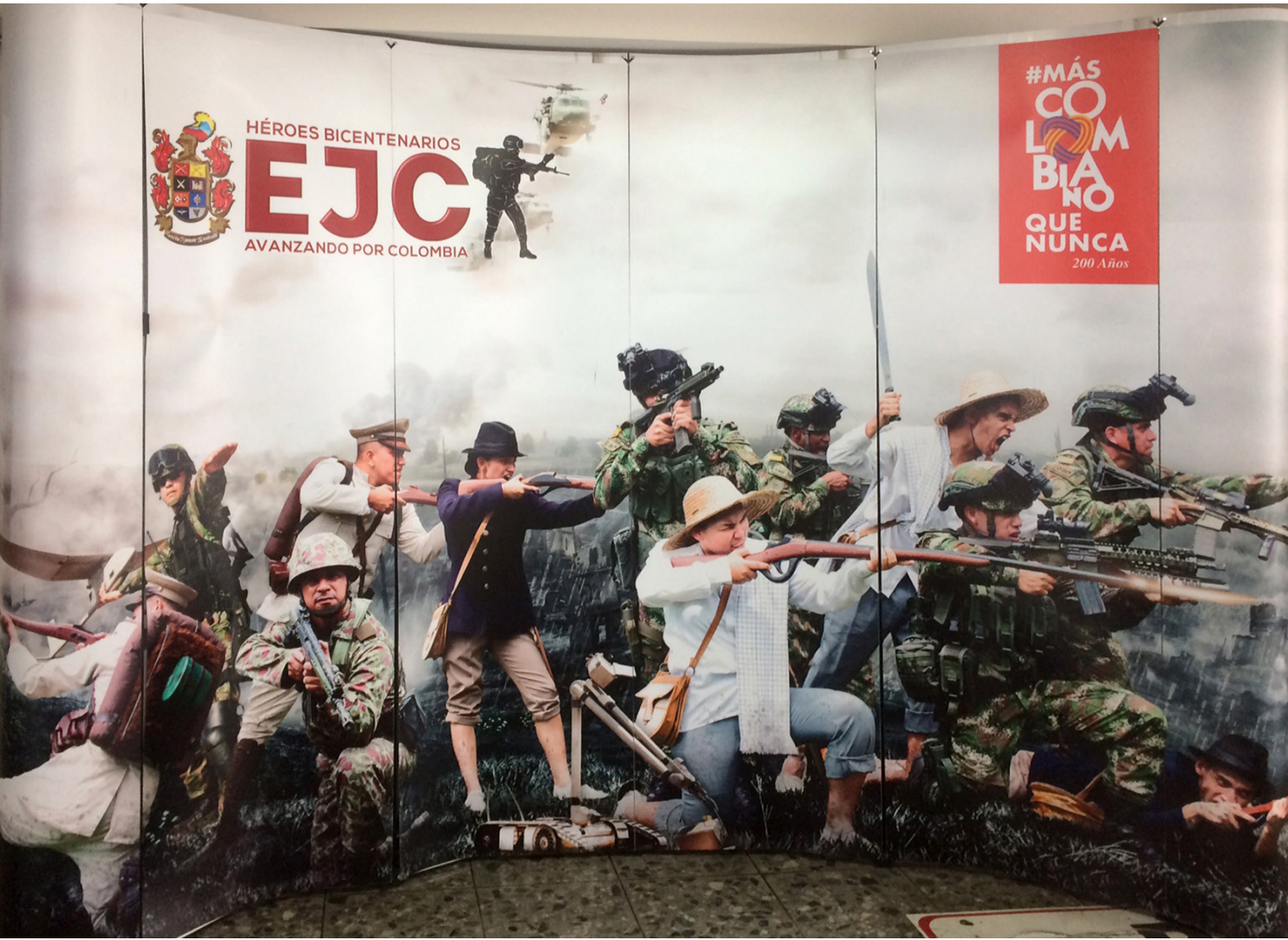


Porque donde hay conflicto civil y masculino -en este drama de tragicomedia no existen las mujeres- termina por apuntarse con mosquetes realistas o patriotas, con fusiles de largo alcance, o en el peor de los casos agrarios, con machetes de cortar caña. Guerra es guerra; lo importante es dar de baja al enemigo, así no lo veamos. Esto garantizará pasar a la historia como un héroe y, en este caso, como un héroe tan antiguo como el conde Drácula, un Héroe bicentenario, más colombiano que nunca.

Si la viajera que arribe a Colombia proviene de Estocolmo, donde cada año se entrega el Premio Nobel de la Paz, tendrá que decir: «iQué horror, adónde he venido a parar! Pero si solo vine a conocer las bondades del Paisaje Cultural Cafetero». Si el viajero memorioso proviene de Bosnia, ante esta imagen deducirá: «Situación difícil la que enfrentan estas gentes. No les basta con el accionar de los soldados, también los civiles se hacen a las armas y comparten el mismo lugar de la batalla». Si el viajero es un ucraniano entrenado en el arte de la guerra, su primer reflejo será protegerse y nada raro que se tire al piso o tome de rehén a un turista chileno, afecto a Pinochet. Su reacción es natural cuando comprueba que allí impera la anarquía, que el enemigo invisible, camuflado en la bruma de las tres cordilleras andinas, ataca por 
[ 34 ] la vanguardia y la retaguardia. Y como si este gesto vanguardista, surreal, no fuera suficiente, hay un soldado en posición de tiro que apunta a los pies del perplejo visitante. Menudo cuadro goyesco.

Nada extraño que la noruega, el bosnio y el ucraniano hayan arribado al país pensando que disfrutarían de un clima pacífico derivado del posconflicto. Esta puesta en escena les anuncia lo contrario y los previene: ¿qué se creen, ah, señoritos del primer mundo? Aquí todavía hay cosas por resolver y muy serias. «Mi profesión es hacer disparos al aire», se lee en un poema de León de Greiff. En fin, si yo fuera ellos, reclamaría mi maleta y buscaría la forma, sin importar sobrecostos y la reducción de la cantidad de millas, de regresar de inmediato a casa: ese nicho ideal, indivisible, de nuestra seguridad democrática. 


\section{Trabajo con altura}

Cuando uno se estrella con estas botas pantaneras a la altura de un sexto piso le invade una sensación de abismal estupor. ¿Algo estará pasando allá abajo, a ras de esa tierra en la que hordas humanas salen a las calles a expresar su malestar frente a las políticas económicas o en contra de presidentes vitalicios y millonarios? ¿Fue inundada la ciudad de lodo y ceniza a propósito de la cercanía con el volcán Nevado del Ruiz y estos dos pares de botas huyen hacia arriba, con la esperanza de la salvación eterna? ¿Las botas industriales han trepado hasta aquí huyendo de la cacería de grupos ecologistas, liderados por Greta Thunberg, que ven en la goma y los materiales sintéticos enemigos contaminantes? Son múltiples las preguntas que ocupan la mente del espectador absorto en el abismo, inquieto en el vértigo de sus fobias. 


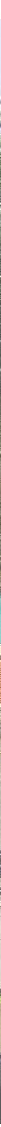


Son preguntas existenciales, por supuesto, que oscilan entre la fuerza de la gravedad y la paradoja de los oficios; y hay razones de peso para hacerlas, sobre todo cuando al mirar hacia el horizonte comprobamos que estamos en un territorio de cordilleras y no en el condado de Manhattan. De manera que hagamos cuentas: el nuestro es un país donde los salarios suben poco; contrario a los trabajadores que sí suelen subir y subir, y no de estatus propiamente.

Hasta hace poco pensaba que un trabajador de altura era el alto ejecutivo de una multinacional, políglota, viajero frecuente y entrenado para hablar de felicidad y éxito ante sus depresivos subalternos. La realidad es poco seria. Un trabajador de altura en esta época de economías naranjas y allanamientos a colectivos de artistas - sospechosos de sembrar la anarquía durante los paros de trabajadores y estudiantes - es aquel capaz de permanecer en lo alto de los edificios, ligero de cuerpo, colgado de un arnés y con una habilidad sobrenatural para mezclar cemento, instalar ventanas, perforar ladrillos, lavar fachadas con líquidos químicos y cantar. Porque los dueños de estas cuatro botas que ven ahí - lo juro por el espíritu de Maria Perego, la mamá de Topo Gigio- están cantando, felices, la letra de una canción pegajosa: 
no me llores que nadie es eterno

nadie vuelve del sueño profundo.

Eterna resulta, para estos trabajadores, la discusión inoficiosa alrededor de la cifra del salario mínimo para el próximo año. Lo eterno es la decisión del gobierno de fijar por decreto esa cifra. Mientras los economistas y los fantasmagóricos líderes de las centrales obreras discuten sobre los índices de inflación, sobre el producto interno bruto y las exigencias neoliberales del Fondo Monetario Internacional a los gobiernos del gota a gota; esta pareja de trabajadores de altura, heredera de la fibra proteica del Hombre Araña, prefiere cantar, pues saben que nadie vuelve del sueño profundo y por eso al cantar permanecen despiertos, como aves pensativas, exhibiendo sus botas al aire, desafiando las leyes de la gravedad. Como van las cosas no solo en nuestro país sino en el mundo laborioso de Occidente, los trabajadores desde lo alto, como poetas ultradinámicos, volverán a gritar, clavando sus ojos hacia la tierra, esa sabia consigna soviética de «iProletarios de todos los países, uníos! Después de las cinco bajamos, parceros». 


\section{Derecho a dormir dignamente}

Novena alocución del señor Presidente de la República

Colombianos y colombianas.

Después de este saludo inclusivo y una vez logré soportar con analgésicos y valeriana el ruidoso paro nacional del pasado 21 de noviembre, admito que es la primera vez que los escucho con atención. Entre tanto ruido de arengas y tantos actos de vandalismo por nuestras queridas calles y plazas, hoy me enteré de muchas cosas que trasmitiré a mis ministros. Ojalá me escuchen.

Pero debo confesar que el acto vandálico que más perturbó mi calma fue el cacerolazo acontecido después de las siete de la noche en diferentes barrios y localidades. Gentes deambulando por ahí en 
pantuflas, señoras en pijamas, pensionados en chanclas de estratos variopintos. Ese cacerolazo me hizo despertar de un sueño intranquilo, como si de repente alguien me hubiera arrojado, en forma de un monstruoso insecto, en la plaza principal de Caracas.

Quizá ustedes no se percaten de lo difícil que es dirigir este país convulso. Quiero que sepan que estoy despierto desde las primeras horas de la madrugada, que pego mi oído a las cadenas radiales, en especial La $W$ de Julito, para saber cómo va mi país y después de ducharme, de acicalarme, llamo al jefe de mi colectividad a ver qué se le ocurre ordenarme. Son dos asuntos muy complejos los que debo resolver día a día, compatriotas: por un lado, están sus reclamos, sus demandas, esa quejadera petrista que me tiene al borde de un ataque de colesterol. Nada nuevas, por cierto, sus demandas, su quejadera. Le ordenaré al director Acevedo, el de Memoria Histórica, que las agregue a los folios que un día serán interpretados por nuestros más dilectos historiadores, hijos de militares y diplomáticos. Y, por otro lado, están las quejas de mi bancada, esa caterva de egos ultraderechistas y de hato que lo que en realidad quieren es desbancarme. Aún no han superado la derrota de la lid interna de partido que me escogió a mí, un chico naranja de 43 años y que me señaló esta Casa de Nariño, tan mal ubicada en el centro de la ciudad, como mi casa 
[42] transitoria y que me ha dado un merecido lugar en las páginas de Wikipedia.

Aunque de lo que hoy quiero hablarles, compatriotas, es del cacerolazo, eso que un periódico de la oposición denominó, no sin sorna, como «el mejor concierto del año». ¿Cómo enturbiar la calma de nuestro amado país, la serenidad de una nación consagrada al manto de María, al escapulario de la Madre Laura y a los positivos de nuestras honrosas fuerzas militares, después de las siete de la noche? ¿Cómo martillar y golpear cacerolas, ollas a presión, pocillos de aluminio en medio de la austeridad en la que he insistido en mi gobierno dietético, de cero mermelada? ¿Hasta dónde irá esta informalidad, este chasquido de trastes fabricados en la China de Mao, este desafuero que nos impide llegar a casa a descansar apenas unas pocas horas?

Compatriotas, en breve ordenaré a Nancy, ministra del Interior, que haga efectivo el Decreto $N^{\circ}{ }^{1121}$, según el cual se prohíbe hacer ruido después de las siete de la noche, desde las selvas del Guaviare hasta los resguardos indígenas del Cauca. Se comprende que en esta demarcación territorial incluyo a las ciudades y pueblos del Paisaje Cultural Cafetero. No estoy declarando la conmoción interior. No es mi interés revivir el clima del Estatuto de Seguridad ni mucho menos 
estoy animando la coerción con los toques de queda en un país de clara vocación democrática. Solo exijo, a nombre de las colombianas y los colombianos, de los insomnes y las insomnes, el sagrado derecho a dormir dignamente. Buenas noches y que el Niño Jesús de Atocha vele su sueño. 



\section{Lo positivo: preguntar por la verdad}

No es una estadística señalada por el DANE en materia de nuevas familias que han superado el índice de pobreza. Tampoco es una cifra de nuevos empleos y mucho menos el número de campesinos que se han profesionalizado en el Sena este año. La cifra señala un número de víctimas y un solo interrogante: «¿Quién dio la orden?». Vaya pregunta. ¿La orden de qué? La de asesinar a 5763 personas. Es difícil pensar que la orden la diera un solo individuo y por eso allí aparecen, en cadena, cinco oficiales de alto rango. Con unos números problemáticos sobre sus cabezas, como si cada número les diera un lugar de privilegio en un certamen, como si a ese número debiera colgársele una silueta humana por cada persona muerta. Tremenda escenografía con sombras y sombras. Le compete a la justicia esclarecer los hechos 


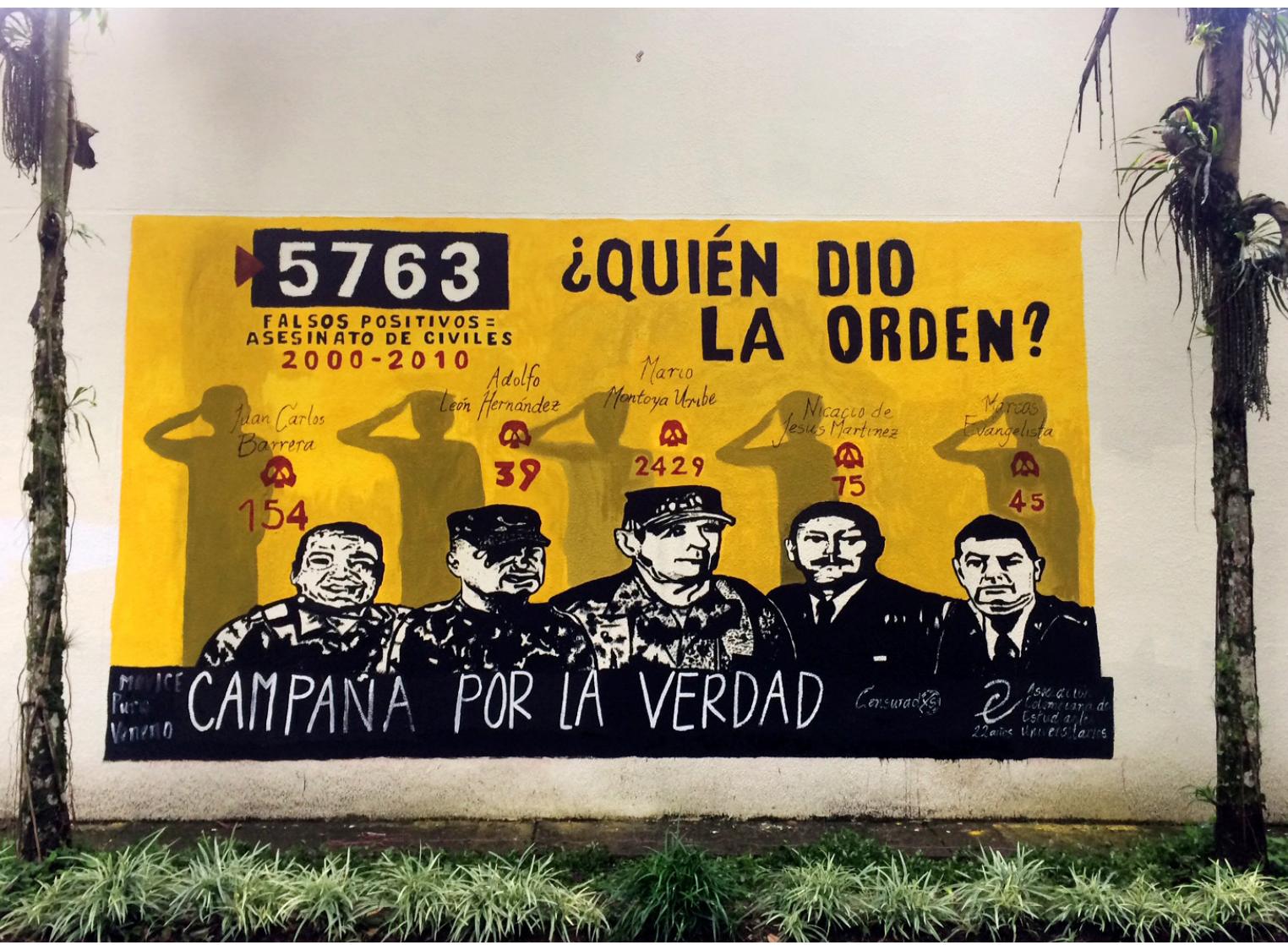


-dirá el lector-, verificar esos números y determinar responsabilidades. ¿Pero cuáles? Bueno, responsabilidades en relación con los eventos en que 5763 personas perdieron la vida.

La cifra se ha conseguido en diez años, según cuentas de la Asamblea de Estudiantes Universitarios. Pero hagamos esta simple operación matemática: si en diez años sumamos 3650 días y el número de víctimas asciende a 5763, quiere decir que por día fueron asesinadas cerca de dos personas. Si pensamos en las víctimas del municipio de Soacha, cuyas madres y parientes siguen llorándolos, estamos hablando de personas jóvenes en su mayoría. Los relatos de los deudos suelen coincidir en que un día cualquiera a estos chicos les prometieron un empleo, les pintaron un negocio, les hablaron de probar suerte en otra parte y luego aparecieron muertos. Y no era una muerte cualquiera: sus cuerpos aparecían en una supuesta zona de combate. Así que en el argot militar habían sido dados de baja y, en las estadísticas de la Seguridad Democrática, se estaba ganando la guerra. ¿Por qué darles de baja y no capturarlos? Porque presuntamente eran guerrilleros, subversivos, individuos beligerantes preparados para el combate y enfrentados contra la autoridad verde oliva. 
«De seguro, esos muchachos no estaban recogiendo café», dijo en su momento un presidente de la república, es decir, el jefe máximo de las fuerzas militares. Como si de este modo se justificara el acontecimiento: puesto que no estaban cogiendo café era necesario darles de baja y sumar con ello un positivo. Ilustro: entre las tropas en combate, dar de baja a un guerrillero es un éxito, un acto positivo con el cual se asciende, se ganan medallas, se adquiere prestigio, se dispone de días de licencia para estar en familia, se hace mérito para engrosar la lista de los destinos heroicos. Pregúntenle al general retirado Mario Montoya.

Pero lo positivo, después de todo, resultó falso. Digamos que estos 5763 colombianos no estaban cogiendo café ni aspiraban a ser gerentes de la Federación Nacional de Cafeteros, pero tampoco estaban en el campo de batalla ni se les pasó por la mente enfrentar los soldados de los generales Barrera, Hernández, Martínez, Evangelista y, otra vez, Montoya. Los familiares de los muertos de nuestra Comala aún reclaman dos cosas: que a sus parientes les reconozcan el derecho al buen nombre y que se sepa la verdad de lo que sucedió con ellos. Porque el grafiti es claro en la ecuación: falsos positivos = asesinato de civiles. Los civiles somos quienes no pertenecemos a alguna de las armas del ejército ni empuñamos 
armas en nombre de una organización subversiva. ¿No había otra forma de llamarlos? Si de algo se precia la historia del país es la de tener una larga tradición retórica, la misma que permite hablar de la corrupción como un problema que debe reducirse «a sus justas proporciones».

Falsos positivos. Aludimos aquí a una escena camuflada en gótico, de teatro en vivo, que nutre una amplia videoteca histórica: 5763 productos snuff. Hablamos de falsificar un escenario de guerra y ubicar en este, a la manera de un objeto de utilería, el cuerpo de un inocente caído en el combate de la perversión. Ni Poe, tan afecto al articulo mortis y a la necrofilia, imaginó escenas tan brillantes en su oscuro tratamiento de las sombras. 



\section{Un país de sabios}

El primer sabio que habitó entre nosotros, cuando aún el mundo era muy reciente, pertenecía a una familia gitana. Se llamaba Melquiades, decía poseer las claves de Nostradamus y llegó a Macondo un mes de marzo como integrante de un circo que viajaba por el mundo exhibiendo, a cinco reales, los últimos inventos. Era un hombre grande, de barba montañera y manos pequeñas. Primero exhibió un imán gigante y lo mostró como la octava maravilla de los alquimistas de Macedonia.

$\mathrm{Al}$ año siguiente, Melquiades mostró los poderes de una lupa enorme y un catalejo y no dudó en promocionarlos como descubrimientos de los judíos de Amsterdam. Si bien dejó perplejos a todos los habitantes de la aldea con los poderes de estos objetos exóticos, nadie quedó más sorprendido con sus bondades que José 
Raul Gonzalo Cuero fengifo 
Arcadio Buendía; tanto, que insistió en comprarle estos objetos

al gitano para aplicarles reingeniería. Con ellos, emprendió sus propios experimentos y aunque no logró demostrar nada sobrenatural ni hacer de sus experimentos realidades asombrosas, al menos consiguió afinar su carácter sabio, pues «tenía la abnegación de un científico».

José Arcadio fue el primero entre nosotros en detentar un espíritu científico. Y fue el primero, además, en construirse un gabinete, es decir, un laboratorio, fuera de su casa familiar, «para que nadie perturbara sus experimentos». Gracias a su obsesión natural por la ciencia y el conocimiento derivado de sus observaciones experimentales, fue el primer habitante de Macondo en descubrir que la tierra era redonda como una naranja.

Cuando su mujer y los vecinos pensaron que José Arcadio se había vuelto loco, arribó Melquiades en su auxilio y pareció convencer a los aldeanos de que ese hombre era inteligencia pura y capaz de llegar a conclusiones científicas por cuenta propia. Fue entonces cuando el gitano le regaló un laboratorio de alquimia y el mundo para los Buendía dejó de ser triste desde el martes. Así, fue más fácil comprender, en vida comunitaria, cómo funcionaba la máquina para olvidar los malos recuerdos y cómo transportar- 
[54 ] se en la estera voladora. Fue simple entender, sin aspavientos, por qué Melquiades podía quitarse la dentadura postiza; por qué una gallina ponía huevos de oro y un mono amaestrado poseía la terrible virtud de adivinar el pensamiento. José Arcadio tuvo el deseo de construir una máquina de la memoria en la que pudiera almacenarse el recuerdo de todo lo nuevo que llegaba a su pueblo.

En fin, el conocimiento se tradujo en asombro permanente, como cuando una segunda generación de gitanos, tras la muerte de Melquiades, llegó a Macondo con otros inventos. El mayor de todos fue un bloque de hielo, esa «portentosa novedad de los sabios de Memphis», al que José Arcadio confundió con el diamante más grande del mundo. El capitalismo empezó a ser su agosto y eso lo comprobó nuestro primer científico al pagar treinta reales para ver el hielo, otros cinco para tocarlo y otros diez para que sus hijos pudieran hacer lo mismo y experimentar con lo nuevo.

He aquí los gérmenes de nuestra proclividad a ser sabios. El actual gobierno anunció la creación del Ministerio de la Ciencia, aunque antes anunció la conformación de una comisión de cuarenta y un sabios capaces de proyectar el destino del país por los caminos de la ciencia, la tecnología y la innovación naranja. Pero ya que estamos en los tiempos del capitalismo inconforme 
de las masas y en la época en que las cosas dejaron de valer los reales de Macondo, me pregunto si vale la pena reunir tantos sabios para escribir un documento que oriente la abnegación científica del país.

¿Qué pensaría José Arcadio Buendía de esta comisión? ¿Se arriesgaría a participar en ella en el remoto caso de que fuera convocado? ¿Alguno de los cuarenta y un sabios de esta nueva comisión -la primera se creó hace veintiséis años y solo tenía diez sabios, entre ellos el biógrafo de Melquiades- habrá leído el libro Una triste aventura de 14 sabios, escrito por José Félix Fuenmayor en 1928 ?

Antes de que alguien me aclare estas inquietudes, permítanme deslizar otros interrogantes: ¿sabe usted del paradero del científico Raúl Cuero y por qué este microbiólogo no hace parte de la última comisión de sabios? ¿Qué protocolos experienciales lo apartan de la posibilidad de ser el sabio número 42? Propongo que este hombre, heredero de los planteamientos teóricos del monje Hermann y excientífico de la Nasa, sea el primer ministro del Ministerio de la Ciencia. Es hora de exaltar los orígenes y las realidades inventadas por un gitano sapiente, que sucumbió a las fiebres en los médanos de Singapur. 



\section{El sueño de Greta Thunberg}

Tras un desmayo que duró dos días, Greta Tintin Eleonora tuvo al fin la certeza de su soledad y su derrota. Despertó sobresaltada a las tres de la tarde, casi desnuda, con su piel tostada por el sol y la garganta seca. Tenía una brújula en la mano, una mochila con hierbas medicinales del norte de Borneo y a su lado yacía, bocarriba, una tortuga de agua dulce. Le bastó levantarse de la arena y divisar a lo lejos las ruinas de un faro de granito para comprobar que había regresado a Flaten, el lago de su infancia, ese lugar en que vio por primera vez cómo brillaban, en olas frágiles, los peces abborre como si se tratara de arcoíris itinerantes.

Enderezó su cuerpo, pero cuando pretendió dar los primeros pasos rumbo al oriente del lago, en busca de una cabaña de madera en la que solía jugar a las escondidas con su hermana menor, advirtió que no tenía pies: solo tenía un pedazo de piel que le 


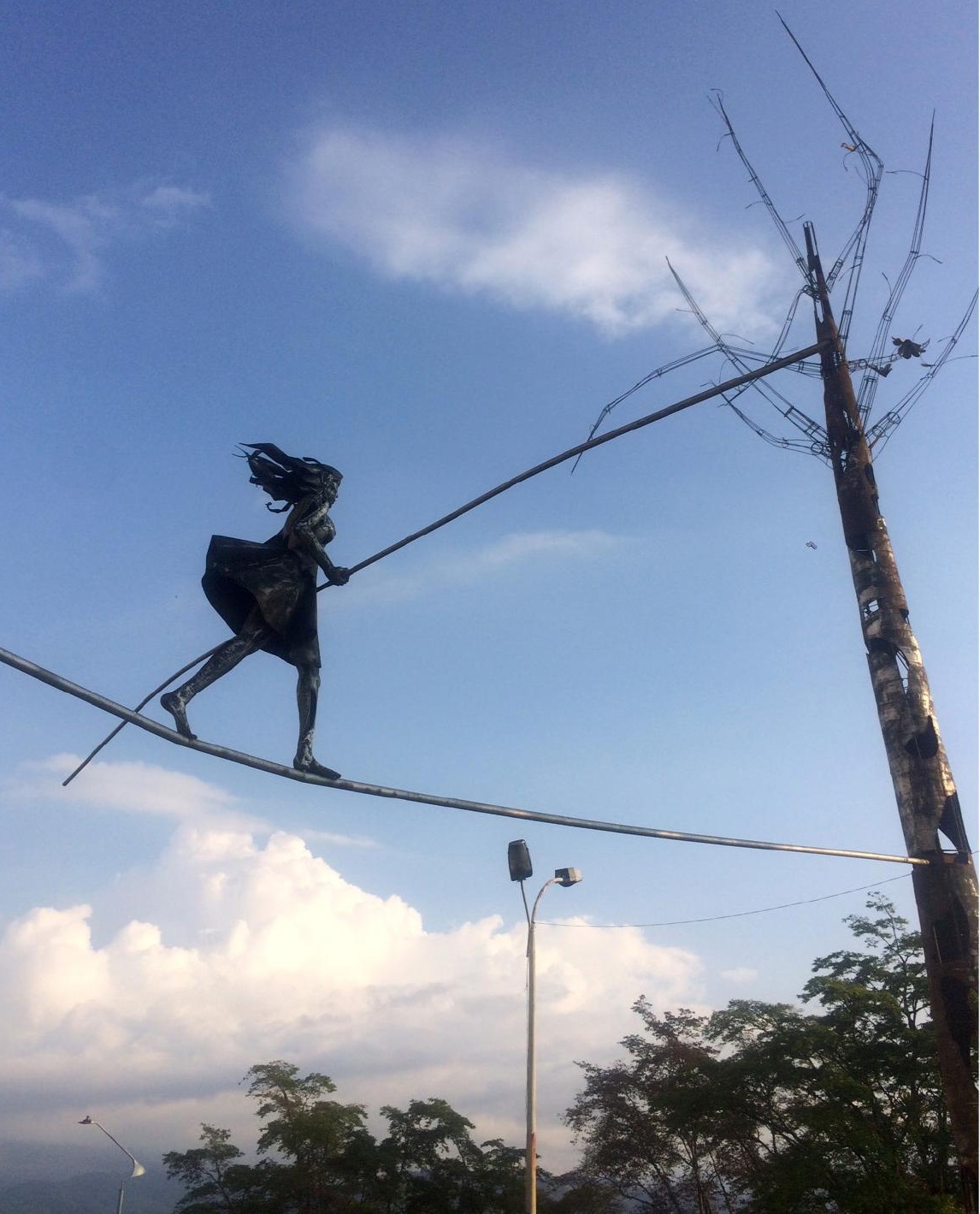


colgaba de una de sus extremidades inferiores. Sufría, admitió, los efectos del síndrome Forrest Gump. Volvió a sentarse sobre la arena, leyó como un enigma apocalíptico los números que señalaban la aguja imantada de su brújula; escuchó a lo lejos el ruido estridente de un avión de British Airways y empezó a acariciar el lomo áspero de la tortuga. Cerró sus ojos lastimados, casi sin párpados y se vio a sí misma caminando en las alturas de un cielo profundo sobre un cable trenzado, de dureza industrial. Buscando mantenerse en pie con la ayuda de una garrocha, Greta Thunberg, la adolescente que decidió cargar con el desastre del planeta, estuvo a punto de perder el equilibrio cuando descubrió que algunos árboles de su mundo en peligro eran metálicos.

Entonces lo recordó todo: su correría interminable por cuatro continentes con una biblia ambiental en su mano pregonando el evangelio según Francisco de Asís; sus discursos ambientales, algunos surrealistas y amazónicos, en las ONG y los parlamentos, para molestia de unos mandatarios bufones que no ocultaban sus deseos de castigarla como a sus nietas melindrosas; sus viajes en velero por las aguas torrentosas y frías del Océano Atlántico a bordo del Malizia II, como si fuera la protagonista femenina de Waterworld. 
[60 ] Greta Tintin recordó, además, la no menos cinematográfica huida por las calles laberínticas de Marrakech, cuando una caterva de neofascistas magrebíes quiso lincharla en la plaza de Jamaa el-Fna. Pero un chico de diecinueve años, alto, vigoroso y rubio la trenzó en sus brazos de sultán multicultural, la subió en su caballito Royal Enfield de 350 centímetros cúbicos y la condujo, sana, salva y enamorada, hasta los muelles del puerto de Essaouira, donde la esperaba un barco azul con víveres veganos para quince días. Badi Bichir, su Jack Frost, la besó con eterna dulzura ecológica y le prometió abanderar, por Instragram, una campaña para salvar las ballenas de Islandia. Fue entonces cuando más lamentó que el mundo se fuera a extinguir, sin refugio para el amor, como en esas películas fantásticas de DreamWorks.

Mientras buscaba sin suerte la cabeza de la tortuga, Greta recordó que en enero cumpliría veinte años y recordó también su última discusión familiar. Así como impuso su soberana voluntad para no volver al colegio, había querido imponer en noviembre un deseo: tener hijos. Perplejos, sus padres, nuevos practicantes del Tao, escogieron los argumentos más políticamente correctos que habían aprendido en su larga correría por el mundo al lado de su hija, pero no lograron hacerla cambiar de parecer. 
- Quiero concebir un niño y una niña para perpetuar la especie - sentenció Greta, mientras se alimentaba con frutos secos.

- ¿Acaso crees que nuestra casa es el Arca de Noé? - la cuestionó su hermana Beata Mona, feminista radical y activista en favor del alquiler de vientres.

Pero Greta no escuchaba a nadie ni parecía dispuesta a hacerlo. Solo quería escuchar lo que su corazón le dictaba. Y lo que su corazón le dictaba era trágico. 



\section{El Niño Dios}

Para Diana P.

La vida de Jesús no fue simple. Desde que se supo que era el elegido y llegaría al mundo con un mensaje encriptado en la sustancia de la metáfora-sentencia «Yo soy aquel que soy», se convirtió para muchos profetas energúmenos, de religiones politeístas y tribus de hacendados, en un temible oponente. Fue la época en que el mundo era tan reciente que algunas cosas y puntos geográficos carecían de nombre. Aquello verdaderamente antiguo en Judea era la necesidad humana de creer en lo inefable y en el misterio. Jesús interpretó ese menester, o la voz del Padre le tradujo con parábolas ese menester y se hizo hombre para hacerse más creíble y urgente. 

La infancia de Jesús no fue sencilla. Las primeras noticias de los cronistas dan cuenta de la odisea que enfrentaron sus padres, José y María, para salvarlo de la ira de Herodes el Grande, un tipo irascible y controlador, capaz de ordenar la muerte de quienes consideraba sus enemigos, incluyendo a miembros de su parentela, si percibía en ellos algún atisbo de ambición por su reinado ubérrimo. Uno de sus consejeros más eruditos, experto en el arte de la criptografía nazarena, lo previno más o menos con estas palabras: «Nacerá una criatura que disputará tu lugar; trátase de un ser iluminado por la gracia de la palabra arcana, de la lingüística hebrea. La verdad, no parece de este mundo. Es un líder nato».

Herodes, educado en la celotipia y el pragmatismo, ordenó desde su trono la muerte de mujeres embarazadas y niños recién nacidos. Puesto que no sabía el nombre de su enemigo ni los rasgos de su fenotipo, todos los vástagos recién nacidos eran su enemigo. Para ello, ordenó hacer un censo, una lista negra.

Los padres de Jesús comprendieron de súbito la estratagema institucional, recelaron de la estadística y huyeron por senderos 
[66 ] oscuros y caminos pedregosos, signados por la pobreza de un viejo carpintero que dejaba atrás su taller y sus herramientas. A fuerza de proteger a su heredero se hicieron desplazados. María dio a luz en una caverna, en condiciones poco asépticas. Había en esa gruta, no obstante, un resplandor, una nube luminosa. Con todo y su fe, los nuevos papás tuvieron sus dudas metafísicas en la madrugada del 25, cuando sintieron la gelidez de la pobreza y pensaron en el futuro y la educación de su primogénito. El pesebre de Belén, con luces de colores y animales serenos, fue en realidad la traducción de un artista neobarroco, un tanto agnóstico, que prefiguró el performance como una práctica noble.

Resignados moradores de la gruta simbólica, María y José sospecharon que Jesús no les pertenecía, que su destino era también para ellos un enigma. Habían sido solo un instrumento de fe y con eso bastaría para ser eternizados por el pincel de Tiziano y Bonifacio de Pitati. No era necesario que se preocuparan por su futuro y educación. Era como si el niño hubiese llegado a su realidad terrena con todo incorporado. En un pasaje de los Evangelios apócrifos la singularidad de la criatura perseguida se describe de este modo: «Y, a los nueve meses, Jesús dejó espontáneamente de amamantarse en los pechos de su madre. Y, al notarlo ésta [sic] 
y José, se admiraron en gran manera, y se preguntaron el uno al otro: ¿Cómo es que no come, ni bebe, ni duerme, sino que está siempre alerta y despierto? Y no podían comprender el imperio de voluntad que ejercía sobre sí mismo».

A su primer maestro en el conocimiento de las letras, Gamaliel, le bastó verlo para anunciarle a José que su apuesto hijo «no necesita estudiar, quiero decir, que no necesita oír o comprender las lecciones de nadie. Porque está lleno de toda gracia y de toda ciencia, y el Espíritu Santo habita en él, y no puede de él separarse». Diríamos que fue el primer chico de aquellos tiempos, desescolarizado, en beneficiarse con la Promoción automática. Por eso no fue sorpresa para nadie, ni aún para los ancianos más escépticos del antiguo reino de Moab, por qué Jesús, siendo niño, tenía el poder de hacer milagros, de comprender lo incomprensible y de discutir el contenido de las sagradas Escrituras con los doctores de la Iglesia.

A diferencia de muchos líderes mundiales que escriben sus memorias para limpiar su imagen sórdida o contratan un ghost writer para que relate sus vidas imaginarias, Jesús hizo de su asombroso destino un relato oral. Borges, que todo lo leyó y comprendió en sus ojos sin luz, llamó la atención sobre un hecho 
[68 ] tan leve como recóndito: «Salvo aquellas palabras que su mano trazó en la tierra y que borró en seguida, no escribió nada». Si fuéramos a abreviar la historia en Occidente, pensaría que en la búsqueda de esas palabras borradas se nos ha ido la vida. Jesús, afirma Borges, «no usó nunca argumentos». Y es comprensible: nada se argumenta si se tiene fe, si se cree. «La forma natural de su pensamiento - continúa Borges- era la metáfora», es decir, la belleza. Y aunque seamos proclives a hacer listas negras, a crucificar inocentes ambientalistas en La Guajira, a traicionar a los amigos con besos en la mejilla, perseguimos la belleza: esa forma indecible de la vida eterna. 


\section{La economía naranja}

La poesía sucede al borde de la acera o, como diría Whistler, el arte sucede. Esa fue la revelación que obligó a Ryan Cross, un californiano con aspecto de rockstar y ligero de equipaje, a quedarse a vivir en Pereira. Una mañana de septiembre lo despertó el pregón de un vendedor ambulante que ofrecía aguacates a buen precio. Encontró en esa voz lo que no había encontrado en Allen Ginsberg y sus secuaces: un aullido con forma de pera que brota de la tierra sin más; un gorgoteo que deja de ser semilla para transformarse en cuerpo sensual, como la guayaba fresa, como la mandarina clementina, como el mango Haden.

Había allí, en el pregón ambulante, una sonoridad profunda que se enredaba en el aire, unos gritos mistéricos que invitaban al silencio contemplativo. La ciudad murmura endechas, caviló, 


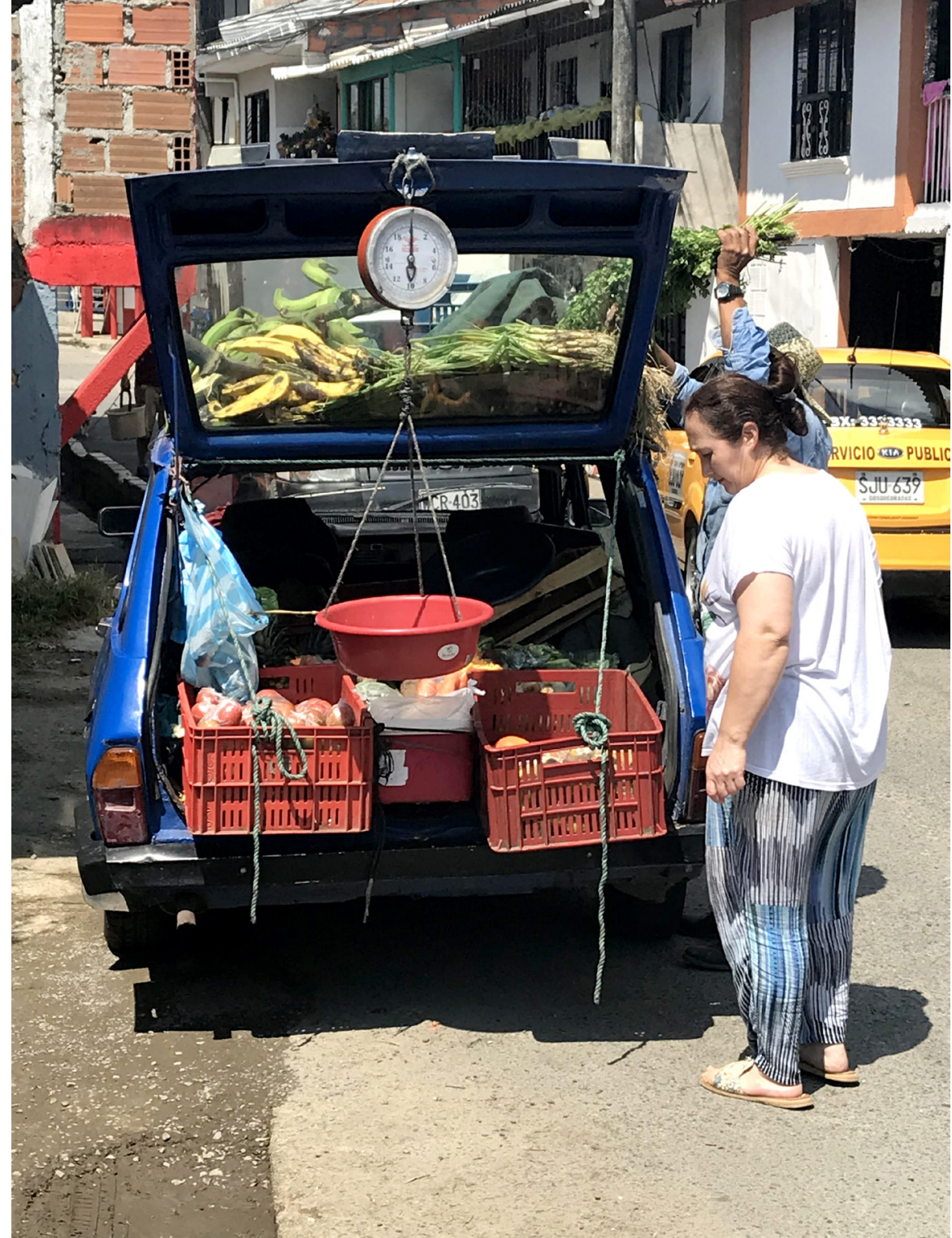


captura en las voces del rebusque una queja festiva, milenaria. La urbe ostenta unas ampollas profundas a fuerza de resistir el lastre de la economía descalza.

Tembloroso, Ryan no dudó en bajar los cuatro pisos de su apartamento para comprar su primer aguacate. Detrás de la fruta vio a Don Arbe, un hombre inocente y cansado. El hombre le señaló a lo lejos el verde de la región cafetera y le dibujó en el hollín de la esquina una montaña. Palpó el aguacate, lo peló, lo olió y lo engulló. Ante su avidez el vendedor lo previno: la cáscara no se come.

Ryan no volvió a ser el mismo; algo inusitado había ocurrido en sus papilas gustativas. Era aún temprano para sospechar que esa fruta, la Hass, podía importarse y ser un hashtag (\#), una tendencia de la economía naranja en tiempos de gobiernos frívolos.

Indigesto y atacado por la poesía sonora, Ryan quiso ampliar los sabores tropicales y se entregó al vicio de la lectura, una vez escrutara el cifrado sabor del cilantro en la superficie del caldo de pescado. Primero leyó en la cocina de Miguel Hernández:

La cebolla es escarcha

cerrada y pobre:

escarcha de tus días 
[ 72 ] y de mis noches.

Hambre y cebolla:

hielo negro y escarcha

grande y redonda.

Luego, fue hasta la despensa donde Neruda guardaba su fruta prohibida:

quiero

una ciudad, una república, un río Mississipi

de manzanas,

y en sus orillas

quiero ver

a toda

la población

del mundo

unida, reunida,

en el acto más

simple de la tierra:

mordiendo una manzana. 
Pasmado ante las extrañas formas de las frutas tropicales del mercado cubierto de la 41, leyó, para sosegarse, una plegaria de José Manuel Arango:

bachué, señora del agua, enséñame a tocar la fina pelusa bermeja del zapote.

Ryan se bañó en pulpa dulce y se secó con hojas de bijao.

Aunque no comprendió del todo el arbitrio de García Lorca según el cual

Nadie come naranjas

bajo la luna llena.

Es preciso comer

fruta verde y helada

Ryan decidió dejar comida para el día siguiente y salir de su nicho a embeberse de ruido urbano. Cuando su reloj de pulso anunció las diez de la mañana en el semáforo del Barrio San Luis, leyó en la página 18 de un poema de X-504, esta receta para sanar el cuerpo:

La digestión de la pulpa del coco demora cuarenta días y cuarenta noches. Ni mucho, ni poco. 
[ 74 ] Al plátano artón de cáscara roja le falta un grado para ser veneno. Compadre, no coma coco.

Si se ha comido banano y se toma ron, muerte segura. Nadie comió. Ni yo tampoco.

La pepita de la pitahaya si la comes no la muerdas, si la muerdes no la tragues; si la tragas, allá tú.

La pepita de la granadilla si la tragas se te embucha. Para que no se te embuche, mejor que no comas mucha.

Una noche de junio, después de atragantarse con el agua rosa y azucarada de una colosal sandía, Ryan Cross decidió montar un poema sonoro, una puesta en escena del trueque popular de víveres. Decidió alquilar un carro destartalado para convertirlo en una revueltería nómada, no sin antes consultarle al lingüista Noam Chomski cómo carajos podía traducir revueltería a su lengua nativa. Fue la manera que escogió para agradecer el sabor y la textura de los frutos generosos de la tierra quimbaya.

Siempre que los vecinos le preguntan por los aguacates, Ryan Cross responde que están escasos, que no hay cosecha, que siendo optimistas dos arrobas le llegarán el próximo jueves. Este hombre de la calle comercial no es tendencia y se comprende, pues la 
informalidad en un país asesino y latifundista donde todo se revuelve y se etiqueta con la moda impuesta por los «yupis» que hacen cursos de verano en Harvard- es permanente. 



\section{Arde el planeta}

La imagen de un pequeño koala, que llega hasta una autopista a las afueras de Adelaide en Australia y le pide agua a un par de ciclistas, es conmovedora. El marsupial necesitaba calmar la sed de la huida y esta urgencia biológica lo obligó a entrar en contacto con esa especie que por décadas lo ha depredado a causa de su valiosa piel, gruesa y suave, apropiada para manufacturar abrigos y alfombras en las factorías londinenses.

Con su pelaje gris y su nariz en forma de cuchara, el koala parece retener en sus ojos vidriosos el ardor de las llamas que devoran su hábitat nativo, donde se alimenta de hojas de eucalipto. Su especie se ha reducido a la mitad de forma dramática. Sostienen los expertos que tendrán que pasar varias décadas para que algo de lo devorado por el fuego vuelva a su estado natural. De nuevo el equilibrio en el ecosistema se rompe, como el fracking. 
1. FIIIL 4

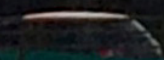
-ititule 
Primero fueron los bosques de Valparaíso en Chile. Luego, fue el Amazonas y ahora son las extensas reservas de bosque australianas las que se extinguen bajo el fuego que se aviva con el intenso calor. Las noticias del mundo redondean, sin aspavientos, las cifras de la tragedia: cuatroscientos ochenta millones de animales muertos en cinco millones de hectáreas destruidas, algo así como la extensión de Bélgica. Más de veinte personas han perdido la vida y se calcula en docenas las desaparecidas. Dejemos de lado el número de viviendas convertidas en cenizas.

Una nube de humo, proveniente de Oceanía, ha recorrido más de doce mil kilómetros y ha sido vista en Chile y Argentina, a unos seis mil metros de altura. El sol rojizo, en las profundidades del sur de América, denuncia su rastro como si se tratara de un mal presagio; no es precisamente el sol de los venados ni las imágenes para un especial de Discovery en busca de los supervivientes de los Andes.

Algo raro pasa. Es bueno aclarar que no se trata del comienzo de un relato del realismo mágico. Para nutrir esa propensión a la desmesura y la hipérbole comparto más bien esta noticia: el pasado 27 de diciembre, mientras los turistas hacían filas para ingresar al Bioparque Ukumarí a contemplar las rutinas perezosas 
[ 80 ] de Mafalda y Yogui, una querida y fértil pareja de osos de anteojos, moría en Tanzania el rinoceronte hembra «más viejo del mundo». Se llamaba Fausta. Este mamífero en vía de extinción llegó a la colosal edad de cincuenta y siete años. Fausta murió de vieja y en una zona de conservación.

En un planeta que arde, a medida que flamea el carácter irascible de Donald Trump en Irán y aumenta la estulticia de Bolsonaro en Brasil, cada vez parece más un milagro, un efecto de lo real-maravilloso, morir de viejo.

Entre tanto, más de diez mil camellos salvajes serán sacrificados por estos días en el sur de Australia, al interior de una reserva de pueblos aborígenes. Los camellos, que huyen de los incendios, buscan fuentes de agua en lugares habitados por el hombre. ¿No es acaso esta una particular versión de Jumanji a lo Mad Max: Fury Road? Solo que en lugar de combatir por apropiarnos de los camiones cisternas que transportan gasolina, las hordas de mamíferos empezaremos a pelear, como animales salvajes, por el agua:

Agua impura

que se escurre

ciega

Susurra Vicente Aleixandre. 


\section{Mataculebras}

Si algo nos enseñó el célebre creador de DMG, el hombre de negocios David Murcia Guzmán, es que para conseguir plata hay que ser astuto y tener fe. ¿Recuerdan las interminables filas de colombianos en los puntos de recaudo de unas oficinas fachada? Unas filas que siguieron aumentando a pesar de que los medios insistían en denunciar que el negocio informal de Murcia Guzmán, un chico excéntrico con cola de caballo, cuyo pasado lo ligaba a la pobreza, era lo más parecido a una estafa.

No podemos negar que era un negocio sencillo de entender: usted iba hasta un cajero de DMG, entregaba cinco millones de pesos, se persignaba y en un par de meses, se daba la pasadita por el lugar del recaudo y retiraba diez millones de pesos. Era un negocio fácil de hacer y solo era cuestión de tener fe y un tris de 
$\underset{E \rightarrow M A T A C l U L B R A S}{\mathrm{CoN}}$

PAGA TODAS TUS

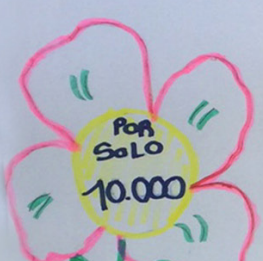

DEUDAS

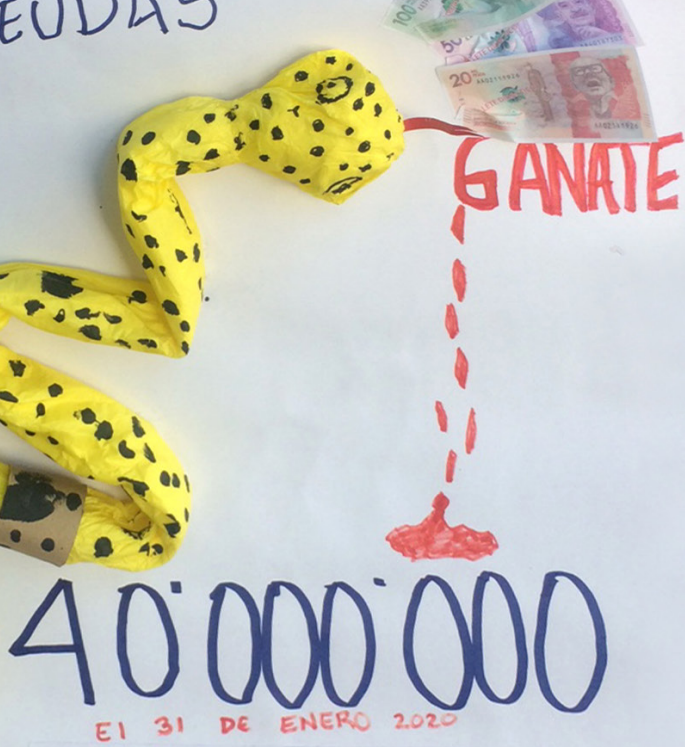

$Y$ además Tiene

Premios Anticipados de $\$ 500.000$ pesos LOS DIAS SABADOS: 4-11-18-25 CON BOYACA 
paciencia; sin necesidad de buscar fiadores, de llenar formularios, de dar referencias familiares y sin la dificultad de utilizar la calculadora para comprender esa ciencia vieja del sistema financiero que interpreta a su antojo la ecuación capital + interés = deuda.

Y para tener fe alguien debe dar testimonio. Y en lo que tiene que ver con el dinero, los testimoniantes, educados en la paciencia y la sencillez desde que hicieron la primera comunión, suelen ser legión.

Recuerdo que un arriesgado periodista, en el punto más álgido del negocio revolucionario de Murcia - su vida de lujos en Panamá era prueba del milagro de la riqueza rápida- llegó con su cámara y su micrófono hasta una de estas filas de fieles que depositaban a ciegas el dinero en DMG y preguntó, en plural, si no les daba miedo perder la plata. Uno de ellos, quizá un profesor universitario, endeudado en los bancos-cooperativas, lo enfrentó en singular y le espetó lo que sus cofrades pensaban: «iDejen trabajar!». Esta es una de las primeras virtudes que ensalzan del colombiano: su buena disposición al trabajo, a la libre empresa, a su capacidad ingeniosa para sobrevivir en el día a día.

Sin haber leído jamás alguna biografía autorizada de Luis Carlos Sarmiento o la familia Gilinski, Murcia Guzmán pensó que 
[ 84 ] podía llegar a ser como ellos. E iba muy bien, sobre todo porque su exitoso negocio piramidal le permitía competir en el mercado de los recaudos. El asunto tiene que ver con el dinero, «el dios vivo que hemos inventado», como sentencia el personaje estafador de una novela de Roberto Arlt. Con el dinero y no con el pasado dudoso de quien lo ostenta. Pensemos en Pablo Escobar, en los Rodríguez Orejuela, en Gonzalo Rodríguez Gacha. Pensemos en Murcia Guzmán, cuando al defender su empresa frente a los cuestionamientos de una periodista, enfatizaba en que la suya era una empresa solidaria. Tenía razón: todo sistema piramidal o de redes de mercadeo - Herbalife, Omnilife o Anway- se constituye en una empresa solidaria, con un principio asociativo y corporativo tomado de Nacho lee: «mientras tú ganes, ganamos todos».

Este cuento del enriquecimiento fácil se acabó cuando al chico Murcia lo apresaron, lo esposaron, lo exhibieron como un criminal con cola de caballo y se lo llevaron en un vuelo chárter hacia una cárcel de los Estados Unidos. Hordas de testimoniantes lloraron la captura de su líder espiritual, mientras exigían a gritos que el Estado, esa cosa amorfa que existe solo cuando estamos en apuros, los indemnizara, pues habían quedado desprotegidos, desamparados. Pero esa es otra historia, otra histeria. 
Sospecho que, ante la ausencia de Murcia Guzmán, el líder colaborativo capturado por lavado de activos, surgió la necesidad de afinar otras formas de hacer dinero o, por lo menos, de impedir su devaluación. ¿Alguien tiene duda de que el sistema del Gota $a$ Gota, esa práctica perversa de pagar exorbitantes intereses a sujetos motorizados que amenazan con bisturí si no cumples con la cuota diaria, no se aceleró después de la caída de DMG? El mensaje es diáfano: siempre habrá otras maneras, tal vez menos objetivas, para hacerse a un capital que nos permita matar culebras, esto es, deudas, cuotas atrasadas, hipotecas, facturas con tijera.

Como crédulos y buenos cristianos, aún tenemos la esperanza de conseguir dinero apostándole al chance, a la lotería, a la rifa navideña y, por supuesto, al Baloto: esa mecánica surrealista, distópica, que sortea la ilusión de convertirnos en millonarios. Esa forma del azar que pende, como las pesadillas, de combinaciones algorítmicas: una suerte de mala traducción de «La lotería en Babilonia». Por más que nos fastidien, soñamos con tener más dinero que Maluma y J Balvin, ese par de parceros libidinosos con suerte reguetonera.

A propósito de pesadillas, recuerdo que una noche de diciembre desperté sobresaltado y sudoroso. Había soñado que mi nuevo 
[ 86 ] vecino, un hombre de cabello largo y dientes incompletos, se había ganado el Baloto. En mi sueño, el tipo tocaba a mi puerta a las siete de la madrugada de un sábado frío, me abrazaba con alegría, mientras me daba la buena nueva de que se había ganado el Baloto. Lo primero que pensé, y esto es materia del sueño, es que entonces yo estuve muy cerca, a una puerta, de ganarme el Baloto. Y lo segundo que juzgué, así suene perverso confesarlo aquí, es que debía liquidarlo, no en términos financieros sino físicos. Y mi accionar, digamos, era cristiano: ninguno de los dos reclamaría el premio. No habíamos hecho méritos, en nuestra vida pagana, para merecer premios. Yo no podía dar fe de que él fuera un buen vecino. Él no podía esperar de mí comprensión, misericordia. En el fondo, ese hombre con suerte era lo más parecido a una culebra, a un vicio adánico. Liquidarlo era el antídoto para volver a conciliar el sueño. 


\section{Perorata de un perro vallejiano}

Qué te puedo decir, no es fácil ser perro en la ciudad. Por más que Fernando Vallejo nos ponga en el mismo lugar de Céline y nos lave los dientes y done sus premios para crear albergues dignos. O Coetzee se conduela de los perros desahuciados en Desgracia. O Carolina Sanín opte por el animalismo y se la vea con su mascota, impetuosa, por el Park Way, mientras denuncia: «No debería haber perros vigilantes». Nuestras circunstancias caninas son tan complejas como el carácter variable de los veterinarios.

Fuera de soportar el peso de la domesticidad cargamos con las neurosis de nuestros dueños, con sus soliloquios mascotiles. Eso de hablar con nosotros, en tono íntimo, no les queda bien: «Mira, mira, Póquer, allá vive tu tío Ernesto. Sí, en el piso siete». Algo va del trauma a la compañía que prodigamos en apartamentos 


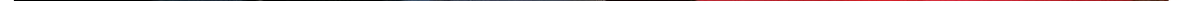


diminutos. Algo se liga entre la soledad del bípedo pensante y esa manía de sacarnos a la calle con bozal y correa, mientras las cacas que dejamos por ahí, con el sol a cuestas, los dueños suelen dejarlas por ahí, en bolsas negras, para molestia de los vecinos.

A propósito de cacas, la ciudad es hostil con sus avisos de advertencia: «Prohibido dejar excrementos»; «Él lo hace por necesidad, yo lo recojo por educación»; «Que tu perro no deje un mal recuerdo»; «Yo tengo un dueño... responsable». En fin: la literatura en la que la palabra «mierda», cara a la literatura colombiana, jamás aparece, es abundante. Deberíamos aprender de las groserías directas y sin ambages de Fernando Vallejo, el San Roque paisa, nuestro patrono de los días azules.

Me enfada que nos exhiban como seres exóticos. De eso algo sé, pues soy un Shar Pei, buen lector, seguidor de la poesía de Li Po, miembro de una raza dinástica y guerrera. No me extraña que un french poodle o un chihuahua me observen como un perro a cuadros. Jamás entenderán la belleza que exhiben mis arrugas, el perfecto diseño de mi hocico. Siempre les parecerá que es excesivo el cuidado que demanda mi delicada piel y más ahora con el calentamiento global. Siempre pensarán que estoy pasado de kilos, que deberían imponerme una dieta rigurosa. 
[ 90 ] Un tipo entrometido, paseador de perros, me puso un sobrenombre que detesto: Sean Penn. Le dice a mi dueño, en la portería del edificio, que lo mío es actuar: que soy perezoso, que arrugo la piel más de lo debido, que soy marrullero con la comida, que ladro mucho cuando estoy solo, que soy histérico. Como verán, entre este individuo y yo no hay buena comunicación y todo se debe a que un día que nos acercó a su casa, le mordí la oreja izquierda a su gata Lola. Una gata fea, sin pedigree, de esas que buscan su hogar en Bienestar Animal Familiar. El otro día se atrevió a sugerir que, si la mía es una raza china, lo más seguro es que me vendan de contrabando en Sanandresito.

Se preguntarán qué hago sacando la cabeza por la ventanilla de un bus de servicio urbano con los colores del glorioso y sufrido Deportivo Pereira. Tengo los ojos cerrados y no es precisamente porque esté disfrutando el viaje. De algún modo debo evitar el smoke que abunda en la zona industrial de Dosquebradas. Pues bien, la necesidad tiene cara de perro. Baste decir que aunque no comprenda de economía, la de mi dueño se fue al traste. Los compromisos financieros no resueltos nos han obligado a utilizar el transporte público. Me siento raro, debo decirlo, porque las gentes me miran con inquietante recelo. Mi sola presencia en 
este acuario en movimiento delata la condición calamitosa de mi dueño y de plano la mía. Tengo claro, eso sí, que prefiero ser futuro usuario del Megacable: ha de ser fascinante ver la diferencia de estratos sociales desde las alturas.

Se preguntarán por qué he decidido perorar. El asunto es sencillo y no requiere de la interpretación psicoanalítica del psiquiatra Alarcón: los de mi especie, en condición canina y actualizados con la protesta social, también tenemos derecho a levantar la voz, a gritar en las plazas públicas: «iPerros proletarios de todos los países, uníos!». 



\section{Favor no tocar}

Ni se le ocurra tocar a esa puerta. Piense que la aldaba forma parte de un simulacro y no de una posible intención tácita: quien habita esa casa espera visita. No se sorprenda que la aldaba se haya instalado allí como un objeto decorativo, con resonancias medievales, conspirativas. Ahora bien, si es curioso y piensa, al parafrasear a Borges que «quizá detrás de la puerta esté Dios», usted podrá acercar su oído a esa superficie de metal y respirar profundo.

Estoy seguro que sentirá un mareo, un vaho de hierbas y especias, como si alguien en la cocina imaginaria de esa casa cerrada estuviera haciendo alquimia con el tomillo, el azafrán y el perejil. Como si al mezclar cebolla roja con casquitos de toronja y trozos de aguacate, bañados en aceite de oliva TreFòrt, el mundo del 


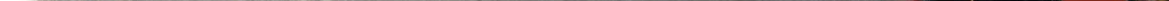


afuera se tornara más dinámico y sensible al asombro gustativo.

¿Qué clase de comida se prepara detrás de esa puerta? Preguntará usted, mientras su paladar saborea imágenes de infancia, como en Ratatouille. Tengo dudas. Quizá sea una mezcla de culturas, una suerte de bazar de confluencias. Sospecho que algo de esa cocina sabe a shawarma, a mejillones en escabeche, a crema de garbanzos, a plátano maduro, a kibbe crocantico, a cuscús y cordero con salsa de yogur.

Pero si usted es de esos curiosos impulsivos que suele percibir los rumores más allá de la cocina, no se altere si escucha golpeteos, si lo confunde el ruido estridente de un cincel, si lo invade el ronroneo de un taladro, si en medio de todo alcanza a escuchar la voz de una mujer que grita: «iEste color naranja destruye la armonía de mi collage!». Si respira hondo y cuenta hasta tres, lo dejará sin aliento el olor a yeso blando y a cemento gris aguado. Será testigo indirecto, por vía del olfato, de la génesis de una obra de arte. Porque la que vive allí es una artista. Esto no quiere decir nada si no agregamos un adjetivo: una verdadera artista. Y las artistas hablan de eso en su soledad habitada: de colores, de materiales duros, de objetos blandos, de resinas, de geometrías, de mayólicas, de pliegues y contornos. 
[96 ] Le ruego que no se confunda: en esa casa no vive Miró, ni Pollock, ni Gaudí; vive una mujer preocupada por las formas del mundo más allá de las preocupaciones de los hombres. Tal vez habiten allí, en armonioso contubernio, los lúdicos espíritus de sus maestros. Algo de su esencia experimental anidará, cómo dudarlo, en el molde de un objeto reciclado, en la rugosidad de un intaglio, en el brote inusual de una hoja de eucalipto tocada por la arena del Cabo de la Vela.

Se llama Viviana Ángel y es huidiza. Por eso presumo que lo de la aldaba es un simulacro, el artificio que se impone como muro: un tatequieto a los curiosos. La comprendo: el artista habita el silencio y en él su obra adquiere cuerpo, supura piel. Sabe, además, lo que vaticinó Gómez Jattin en el nervio de su locura:

El artista tiene siempre un mortal enemigo

que lo extenúa en su trabajo interminable

y que cada noche lo perdona y lo ama: él mismo.

No es difícil declararle el amor a esta mujer, sobre todo si uno aún cree en la belleza como una revelación que no toca a la puerta con frecuencia. Bastará observar sus manos, advertir en la blancura de su dermis la manera sencilla en que esas manos prolongan lo sublime en la materialidad de las cosas. 
No la mire a sus ojos moros, porque jamás cabrá en su mirada. Vive lela, obnubilada, recogiendo cosas, armando cosas, destrozando cosas, inventando cosas. La condición humana, lo pienso a veces, con rigor en horas de la tarde, le interesa poco. Tal vez tenga conciencia de la finitud, de la corrupción del cuerpo, de la memoria histórica de su padre y por eso insiste en alentar la vida en esos pequeños elementos de los que se ocupa en el silencio de su casa.

En lugar de tocar a su puerta admiremos su puerta; esto es, su mundo habitado por el sigilo. En ese ámbito, en ese útero blindado por la puerta con aldaba, imagino sus manos de orfebre ancestral siria prolongando una existencia, un querer ser en la composición de lo inefable.

Créanme: lo que ella forja para nosotros es lo más parecido a una felicidad agradecida, llena de colores y tonalidades preciosistas, un mosaico del deseo y la memoria.

En el principio está ella, con cara de ángel. En el final está su obra, untada de grafito en las partículas elementales de la urbe, como una mermelada de frutos rojos, como un collage que resume los colores de la vida. 



\section{Dilan}

Para Rodrigo Franco

Traga Dilan no brinques Dilan sóplate Dilan no te orines en la cama Dilan no toques Dilan no llores Dilan estate quieto Dilan no saltes en la cama Dilan no saques la cabeza por la ventanilla Dilan no rompas el vaso Dilan, Dilan no le saque la lengua a la maestra Dilan no rayes las paredes Dilan di los buenos días Dilan deja el yoyo Dilan no juegues trompo Dilan no faltes al catecismo Dilan amárrate la trenza del zapato Dilan haz las tareas Dilan no rompas los juguetes Dilan reza Dilan no te metas el dedo en la nariz Dilan no juegues con la comida no te pases la vida jugando la vida Dilan.

Estudia Dilan no te jubiles Dilan no fumes Dilan no salgas con tus amigos Dilan no te pelees con tu hermana Dilan, Dilan no te montes en la parrilla de las motos Dilan estudia la química Dilan no trasnoches 


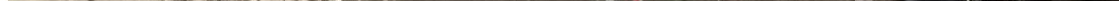


Dilan no corras Dilan no ensucies tantas camisetas Dilan saluda a tu tía Paulina Dilan no andes en patota Dilan no hables tanto, estudia la matemática Dilan no te metas con la muchacha del servicio Dilan no pongas tan alto el tocadisco Dilan no cantes serenatas Dilan no te pongas de delegado de curso Dilan no te comprometas Dilan no te vayas a dejar raspar Dilan no le respondas a tu padre Dilan, Dilan córtate el pelo, coge ejemplo Dilan.

Dilan no manifiestes en la calle, no cantes «El baile de los que sobran", Dilan, Dilan no protestes contra los profesores, no dejes que te metan en la lista negra Dilan, Dilan quita esos afiches del «Che» Guevara, no digas yankis go home, Dilan, Dilan no repartas hojitas, no pintes los muros Dilan, no siembres la zozobra en las instituciones Dilan, Dilan no quemes caucho, no uses capucha, no recojas las bombas lacrimógenas Dilan, no agites Dilan, Dilan no me agonices, no me mortifiques Dilan, Dilan modérate, Dilan compórtate, Dilan aquiétate, Dilan componte.

Dilan no corras Dilan no grites Dilan no brinques Dilan no saltes Dilan no pases frente a los guardias del ESMAD, Dilan no enfrentes a los policías Dilan no dejes que te disparen Dilan no saltes Dilan no grites Dilan no sangres Dilan no caigas:

No te mueras, Dilan Mauricio. 



\section{Popeye el sicario soy}

Acaba de morir Popeye, y no precisamente Popeye el Marino, el eterno enamorado de Olivia, esa chica brusca y anoréxica, cuya falta de modales la hacían más sensual a los ojos y brazos de un marino dicharachero, acostumbrado a comer espinacas para mantenerse en forma.

Quien acaba de morir, a raíz de un cáncer, fue conocido en el mundo del hampa como alias Popeye. Supimos de él en los años ochenta, esa década oscura en la que el país se acercaba al abismo de la anarquía gracias a la confluencia de una serie de implosiones sociales y políticas para las que no había Estado, más allá del estado de sitio en que nos moríamos de miedo.

Admito que nunca me agradó alias Popeye. Me parecía un tipo fanfarrón, ordinario, megalómano y aprovechado, un youtuber de 


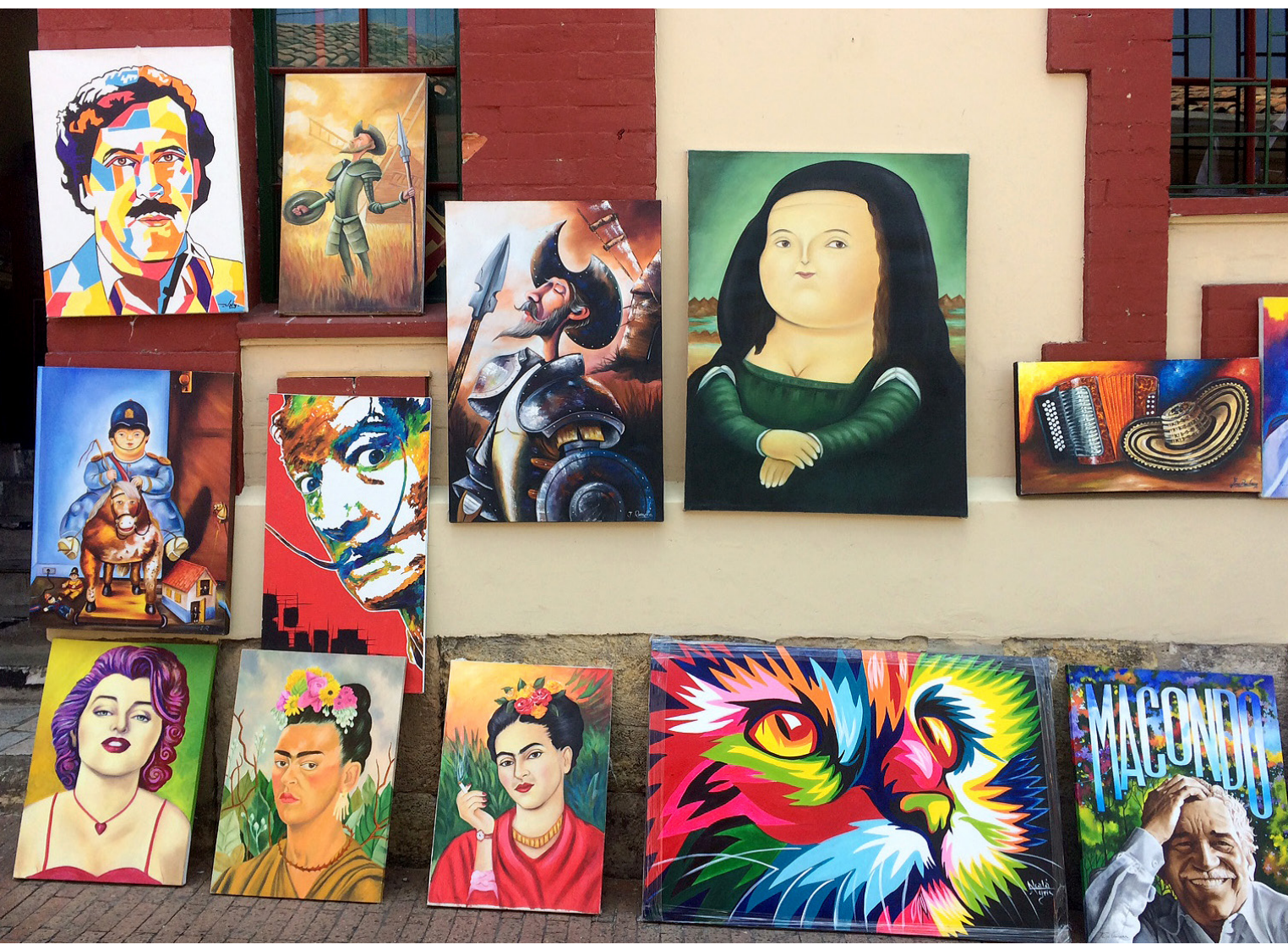


la culebrería. Cuando supo que todos sus cómplices, con quienes

cometía crímenes atroces habían muerto, se dedicó a hablar, que es lo que suelen hacer los fanfarrones. «Habla más que un recluta en su primera licencia», reza la sabiduría popular. Este sujeto tenía la capacidad de hablar por un contigente de soldados.

Alias Popeye nunca supo qué era el realismo mágico, a pesar de que fuera producto de su atmósfera alucinada. ¿Qué tiempo iba a tener para leer un párrafo real-maravilloso si vivía pegado a las series de Netflix? En especial, aquellas en las que algo de su vida criminal se contaba. Solo, alias Popeye era un pobre diablo. Acompañado de su jefe del municipo de La Estrella, era un peligro ambulante, un sicario peligroso hasta para Rosario Tijeras. Su patrón le enseñó que matar podía convertirse en un oficio tan rentable como ser caudillo de un directorio político.

Alias Popeye hablaba en cifras de sus crímenes. A lo mejor pensó: si en Cien años de soledad se afirma, con marcada imprecisión, que en la Masacre de las Bananeras «debían ser como tres mil» los muertos de la estación del tren de Macondo -así lo aseveró el recién resucitado José Arcadio Segundo Buendía-, qué más da decir que mis crímenes debieron ser como trescientos, seiscientos, como dos mil cien. La cifra no importa. Estamos acos- 
[ 106 ] tumbrados a las cifras desbordadas: las del desempleo, las de la corrupción, las de los asesinatos contra los líderes sociales, las del DANE. Lo nuestro es la desmesura. Escuchen a Aida Merlano, o a su hija, la que aspira a ser sexóloga para comprender el misterio de alcoba de Ángela Vicario.

Tampoco importa alias Popeye ni lo que aseveraba ni los supuestos nexos con la clase política corrupta que denunciaba ni los secretos que decía conocer de su Patrón. Importaba su puesta en escena, su Yo me llamo. Porque lo nuestro, para ser justos, es la emulación. Alias Popeye era un émulo y al saber que su jefe había caído, acribillado sobre unas tejas de barro, dedicó su vida a crear un relato a su favor. Olvidó decir que fue el primero de los lugartenientes de Escobar en entregarse a las autoridades. Olvidó contar que buscó rebaja de penas al convertirse en delator, en buchón, mientras su jefe, el hermano de Osito y primo de José Obdulio, se escondía en la urbe con desfachatez e ingenio. Hasta tiempo le quedaba en las noches azarosas a este hombre, antiguo ladrón de lápidas y contrabandista de Marlboro, para leer las tramas de espionaje de Tom Clancy.

Aquí el detalle está en quién le enseñó a alias Popeye a matar, a transformar el crimen en una empresa, a lo Capone, a lo Dillinger. 
Se llamaba Pablo Escobar Gaviria y en su historial de vida este

es el dato más importante: era uno de los hijos más queridos de doña Hermilda, una matrona, profesora de escuela, educada en el catecismo paisa: «Consiga plata, mijo, honradamente, y si no, consiga plata, mijo».

Mírenlo en esta exposición callejera. Es el primero de la izquierda, aunque este hombre en vida solía actuar con sus aliados desde la extrema derecha. Si bien fue un hombre oridinario como alias Popeye - atacado por el acné, pajizo y fanático del fútbol local-, tuvo la proeza de amasar una gran fortuna con el transporte ilegal de drogas. Y ese tipo de gente, capaz de hacerse millonaria, nos gusta a todos: llámese Donald Trump; llámese Walt Disney, el creador del pato Donald. La suya fue una fortuna enorme, tanto, que como en esas historias de Disney, Escobar tuvo su propio zoológico, solo porque a su hija menor le encantaban los animales exóticos: un delfín de agua dulce, las loras negras, los impalas y una tierna pareja de hipopótamos -esa especie animal gregaria que con los años se propagó por las aguas del río Claro, en el Magdalena Medio-. Abatido el capo, quedaron libres por ahí, asustando a los lugareños, mientras se apareaban. No cabe duda: es la gran metáfora fértil de este país salvaje. 
[ 108 ] He aquí a Pablo Escobar Gaviria convertido en un ícono de la cultura pop, como Dalí, como Frida, como las gordas de Botero, como El Quijote, como Gabriel García Márquez, en uno de cuyos libros el hijo de Luisa Santiaga se refiere a Escobar de este modo:

Era rechoncho, con zapatos de tenis y una chaquetilla azul claro de algodón ordinario, y se movía con una andadura fácil y una tranquilidad escalofriante. Villamizar lo reconoció a primera vista sólo porque era distinto de todos los hombres que había visto en su vida.

Estoy seguro que, si Andy Warhol viviera, lo habría pintado con vinilos y polvo de oro en una lata de cerveza o sobre la fachada del Edificio Mónaco. Muerto el artista de La Factoría del Midtown en Manhattan, quedan los de la calle de la Enseñanza en La Candelaria; los de las comunas agarradas como arañas a los cerros; siguen los artesanos que escuchan en las esquinas rumores convertidos en verdades; los que pintan en vivos colores el mierdero de esta vida temeraria. No queda ningún recato para exhibir, en la misma galería ambulante, lo que somos: un frívolo cuadro de costumbres pintado con la viva tonalidad del carnaval. 


\section{Cuando las monjas hablan}

- ¡Ay, sor Teresa, esta madrugada tuve una pesadilla hermética!

- ¡Qué va a ser! ¿Volviste a soñar con que te atacaban pájaros carpinteros provenientes del Vaupés?

-No, menos mal eso no ha vuelto a suceder. Después de la dulce proclama de «Sueños para la Amazonia», los pájaros desaparecieron. Soñé algo peor y no sé cómo contártelo.

-Con calma y con detalle, querida sor Juana.

-Está bien. Soñé que servía en una alta dependencia del Vaticano. Era la primavera. Estaba rodeada de cardenales latinoamericanos que comían pescado en salsa de chontaduro. Discutían, entusiasmados, sobre la conveniencia del matrimonio gay. De repente, en el sueño, la voz del papa Francisco inundó el recinto. 


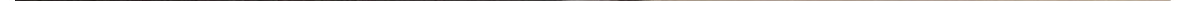


Nuestro padre gritaba a lo lejos: ¡España, aparta de mí, este cáliz!

-iQué horror!

-Sus dos consejeros y yo nos miramos sorprendidos. Discretos, los cardenales se retiraron a sus aposentos. Se reunirían en la tarde a discutir sobre los anacronismos del celibato, así lo dijeron, y me pidieron que para esa ocasión les preparara una lasaña de berenjenas con plátano maduro y carne molida.

-De muy buen gusto los comensales, ¿eh?

-Así es. Una vez solos, decidimos tocar a la puerta del Santo Padre, pero no nos abría. Desde adentro brotaba una voz como de arrabal, como de sangre maleva.

- ¿Y qué más decía nuestro guía espiritual?

-Parecía fuera de sí, alucinado. Tengo confusas imágenes de ese instante, aunque te diría que recitaba un poema extraño, como incoherente. Exclamaba, entre balbuceos y gorgoritos:

Niños, pibes, hijos de los guerreros,

bajad la voz, pelotudos, que España está ahora mismo repartiendo la energía entre el reino animal, las florecillas, los cometas y los hombres. ¡Bajad la voz, que está 
[112] con su rigor, que es grande, sin saber

qué hacer, y está en su mano

la calavera hablando y habla y habla,

la calavera, aquélla de la trenza;

la calavera, aquélla de la vida!

- ¿Cómo es que te acuerdas de toda esa parrafada?

-Lo primero que hice, al despertar, fue anotar ese galimatías. Ya sabes que siempre consulto el libro de interpretación de los sueños de Freud. Ese buen hombre judío alinea mis rutinas en la vigilia.

-Pero vuelve a tu sueño, sor Juana. ¿Qué hicieron ustedes, cómo actuaron?

-Cuando los consejeros escucharon la palabra calavera temieron lo peor. Todos pensamos que el carismático Papa estaba en trance o que estaba siendo atacado por alguna fuerza maligna proveniente de España, ya sabes, eso de los moros, eso de los turcos. Allí habitó, además, el otro Francisco, el dictador Franco.

-Por Dios, no menciones a ese pecador por estos senderos matutinos. Vuelve a tu sueño, te lo suplico. 
-Un conserje alemán abrió la puerta. El Papa no se inmutó al vernos y siguió entregado a la proclama de sus palabras frenéticas. Estaba semidesnudo, con los ojos brotados, mientras enterraba, una y otra vez, una daga antigua en una pintura colgada en su estudio.

- ¿Recuerdas cuál era la pintura que destruía?

-Cómo olvidarlo: era el Guernica de Picasso.

- ¡Menuda herejía!

-No blasfemes, sor Teresa.

-Digo, ¡Virgen santa! No entiendo por qué estás soñando con nuestro Santo Padre. Confiesa la verdad, sor Juana: ¿te quedaste anoche, hasta tarde, viendo Netflix? ¿Ah? Apuesto a que te volviste a ver la historia de Los dos Papas.

-Baja la voz, sor Teresa, que ya estamos llegando a la sagrada iglesia. Sí, para que te lo voy a ocultar. Me volví a ver la película y ya no sé, la verdad, qué pensar de esos dos hombres que hablan y hablan y jamás nos mencionan. Allí aparecen tan humanos, tan contradictorios, tan ellos.

-Razón no te falta. Para mí tengo que hay pecado en el Vaticano. 
[ 114 ] -Para mí también. Que Dios nos coja confesadas.

-Sospecho, amada amiga, que sigues añorando al venerable Juan Pablo II.

-No te lo puedo negar, querida, no te lo puedo negar. 


\section{Bulevar de los héroes}

Para Alberto Berón

Cuando uno nace con miedo necesita de una figura mayor, entre misteriosa y aguerrida, que lo proteja. Ese fue mi caso. Nací con miedo. Miedo a las ratas, a las cucarachas, a los perros Dóberman, a los gatos Angora. Miedo a la gente con sombrero. A los campesinos con machete y carriel. Miedo a la correa de mi madre.

Esa sensanción de vivir indefenso se trasladó a los alrededores del parque principal de mi pueblo. Había allí una atmósfera enrarecida. No sabía explicar su impacto, solo sabía sentirlo. Porque uno a los nueve años siente, actúa y piensa poco. De ese activismo irracional surgió el uso de la cauchera para matar tórtolas. Todo parecía tranquilo, envuelto en una amabalidad silenciosa. Todo 

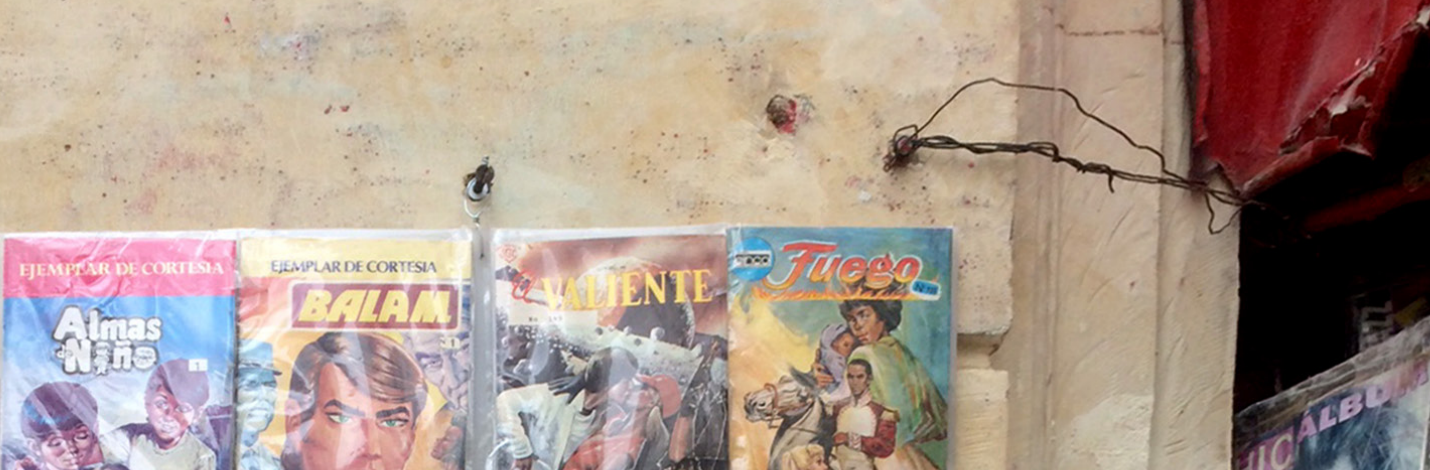
$2 x^{2}(4)=3$

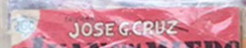

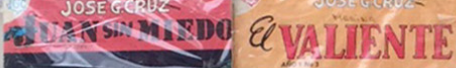
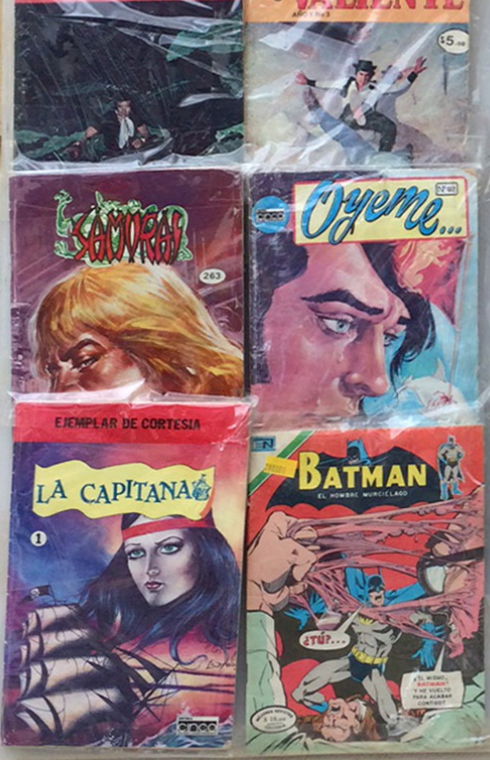

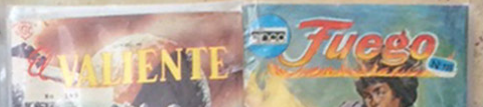
(c)

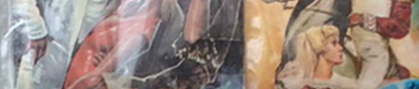

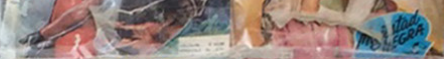

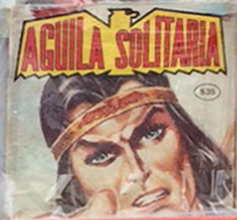

[Dal'OLONGA'

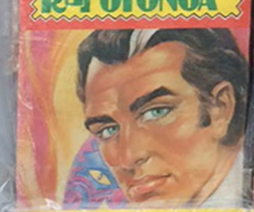

ORTER WVIDAS

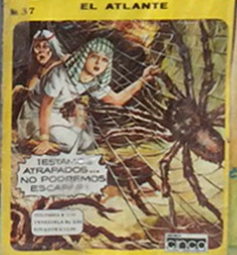

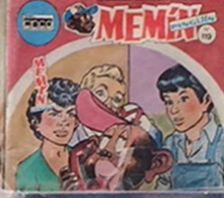
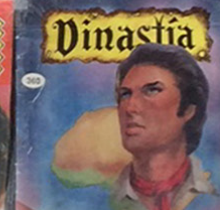
estaba en aparente orden, mientras el carnicero de la esquina destazaba un cerdo y el zapatero de la otra cuadra le daba horma a una suela de caucho.

Sin embargo, en cualquier momento esa tranquilidad era rota por el rumor de una noticia: mataron al menor de los Flórez. Le hicieron un atentado a mi tío en la finca de La Sombra. Doña Bertina, la matrona de La Quiebra, juró desterrar a los cachiporros que comparten con ella los linderos de sus tierras. Hablo de historia patria. Hablo de un miedo generalizado. Hablo en realidad de pequeños y frecuentes cuadros de costumbres.

Imaginemos una visita al dentista, una mañana en que «dos gallinazos pensativos [...] se secaban al sol en el caballete de la casa vecina». Sugiramos que el paciente es un alcalde que lleva cinco días sin poder dormir. Tiene una muela dañada que le ha impedido afeitarse la mejilla derecha y el dentista, un hombre adusto y poco hablador, le informa a su cliente, después de haberse negado a atenderlo, que le sacará la muela sin anestesia. Entre uno y otro se impone la distancia, el resquemor, una historia de silencios. Justo cuando el dentista aplica mayor fuerza en su brazo para extraer la muela dañada, sentencia: 
[ 118 ] -Aquí nos paga veinte muertos, teniente.

Pues bien, en el centro de ese miedo social y dental aparece mi padre con un regalo en su maleta de viajero: los primeros números de unas revistas de aventuras que mi viejo adquiría en un kiosco del centro de Pereira. Cada una costaba cinco pesos. En Venezuela un bolívar. Eran revistas pequeñas, olorosas a tinta, coleccionables, cuyas portadas en colores anunciaban mundos exóticos y en crisis, narrados bajo el imperio emocionante del cómic y el diálogo certero en globitos dinámicos. Mientras esto escribo, observo la portada de la revista 53 de Kalimán, el hombre increíble. Lo increíble es lo que esa portada prefigura: el atentado terrorista del 9-11. Solo que en la realidad de este relato de papel estamos en la década del setenta y el ataque a la tierra lo protagonizan platillos voladores. Una nave parte en dos un edificio emblemático de una posible Nueva York sitiada.

Me tranquilizaba saber que el miedo traspasaba las fronteras de mi pueblo. En esta ocasión, Kalimán debía detener el instinto criminal del profesor Zeland, dispuesto a exterminar la tierra con su escuadrón de platillos voladores. Entre tanto, más allá del Salón de la Justicia, Tamakún, el vengador errante, se enfrentaba a los 
poderes siniestros de la bruja, Mamá Coleta, una astuta anciana capaz de robarle la belleza a las mujeres jóvenes. Desde las altas montañas, desde «el nido de las águilas desciende a las praderas Águila Solitaria», un apuesto indio de gimnasio, líder nato de su tribu apache, cuya misión ahora es liberar a su bella esposa Shiu y su hijo Kei, prisioneros en el barco pirata del capitán Morgan. Mientras esto sucede en aguas marinas, Arandú, el príncipe de la selva, neutraliza el accionar de facinerosos que extraen de los territorios de pumas y leones sus recursos más preciados.

Saber que el miedo y el temor a convertirse en víctima de la violencia imperaba en el mundo, agravaba el miedo infantil. Saber que en algún rincón de la tierra el accionar de Arandú, de Tamakún, de Orión, el atlante, de Batman, de Santo, el enmascarado de plata, buscaba hacer justicia e imponer el orden, suavizaba el temor de seguir creciendo en solitario. Si algo nos enseñó Emma Bovary fue a borrar la línea entre realidad y ficción. El efecto de leer aquellas revistas de aventuas era genial: estábamos a salvo.

Cuando veo en la calle cómo se exhiben estas revistas y cómo, por su valor de material exótico, su precio se ha elevado, pienso en la maleta viajera de mi padre y pienso en los efectos de esa educación sentimental que recibimos por esta vía de papel prove- 
[ 120 ] niente de México. No hay nostalgia en reconocer la raíz de donde emana nuestra cultura. Tampoco hay vergüenza en aceptar que es más fácil crecer, hacerse joven con acné, sabiendo que hay héroes dispuestos a salvarnos de todo mal y peligro. 


\section{Covid-19}

Cafarnaúm, año 2070. Invadida por insectos metálicos, animales bípedos con garras de polietileno, maleza de alambre y púas del tipo campo nazi de Auschwitz, la tierra, la que un día de marzo de 2020 padecimos en estado de calor tropical ChocQuiTown y expuesta al pánico chino que generó la propagación Chernobyl del coronavirus, había desaparecido. O por lo menos se había esfumado en la nube iCloud de la especulación financiera, propia de la lógica cultural del capitalismo avanzado.

La tierra, ese antiguo planeta que giraba alrededor de una estrella solar, en realidad dejó de interesar en la bolsa de valores de Wall Street. La tierra había pasado a convertirse en un emoticón de Microsoft, ahora fusionada con una línea de cosméticos para canes de felpa de la industria Apple. El interés en ese lugar 
de millennials vírgenes y andróginos casados con robots de cuatro orificios hard core, se centró en especular con valores más efímeros: el tierno condón Hello Kitty; el antialérgico tapabocas Peppa Pig; la cámara de sábila capaz de convertir las tetas en un paraíso de polímeros sanos; el vibrador Trump Tower que estimula el placer sexual de la reelección American Dream.

Lo que quedaba en el espacio de capas tectónicas impactadas por el 8.8 chileno - hablamos de efectos sísmicos, no de acciones colaterales de la Junta de Gobierno de Pinochet-que alguna vez habitaron Gandhi y Teresa de Calcuta en Occidente, con sus retóricas filantrópicas, era artificial, casi un desecho: una suerte de réplica de un déjà vu iraquí; un holograma esperpéntico, una invención de Morel. El verde de la naturaleza había sido reemplazado por una ilusión tridimensional alimentada por energía lunar neptuna.

¿Qué quedaba entonces del ingenio humano? Solo restos de capas frágiles, temblóricas, cuyo desplazamiento fue animado por la impredecible fuerza del Cinturón del Fuego del Pacífico. Lo poco que quedaba en la geoespacialidad parecía un dibujo inacabado hecho por un preescolar con mal de Parkinson; una forma del Aleph visto por un bizco libidinoso. 
[ 124 ] No había agua potable, solo productos azucarados de Omnilife. No había yogur deslactosado, solo una miel de purga salitrosa, producida por la multinacional Herbalife. Ambas empresas exigían a los usuarios esqueléticos, inalámbricos, el pago de sus productos en bitcoins. La mercancía pasó a ser un impulso, una vibración; el consumo, un acto reflejo.

Baste decir que el olor atmósferico, eso que los filósofos aristótelicos llamaban la capa de ozono, era mortecino y metálico, como de taller de motocicletas Bajaj Boxer Ct 100 Titannium: una mezcla de orín con amoniaco, una simbiosis de melanina subsahariana con queso suizo encriptado en bóvedas de euros. Entre tanto, el brillo de cobre de los detritus sólidos, su consistencia de mierda jurásica, inundaba las cañerías y perfilaba ríos de lodo pútrido. En algún momento, pensaron en convención los neoecologistas anarquistas del extinto páramo de Santurbán y del simulacro temático Ukumari, que ese lodo desembocaría para siempre en las escasas aguas del río Otún y eliminaría los bebederos de los osos de anteojos producidos en serie, de los kun fu panda anoréxicos y de las truchas plásticas Arcoiris.

Así fue la dimensión del caos, porque así lo había dispuesto el líder rebelde de esta última conspiración ultraterrena: el lisérgico 
Covid-19, una máquina indestructible, de la línea ciborg paraco, maquinodérmica, gobernada por Skynet-II-9/11: esa enigmática inteligencia artificial creada por Steve Jobs, Gustave Redish y Bill Gates, días después del atentado terrorista a las Torres Gemelas.

Covid-19 es una máquina ambigua, un tanto similar a las del ilusionista Almodóvar, un poquitín lista, un poquitín boba. No obstante, carece de sentimientos, porque así lo estipuló el staff de ingenieros teutones de la Hyundai. Robotizado y armado hasta los tornillos inoxidables con cepas del síndrome respiratorio de Oriente Medio, flatos veronianos de los Urales, mucosidades de tres gorilas de Borneo y caca de seis panteras de Sumatra encapsuladas, Covid-19 desconoce la sensibilidad corporal y la emoción ética de las que solía teorizar, en cuarentena, la desaparecida Martha Nussbaum.

En tanto máquina hiperrobótica, Covid-19 es más fuerte que Arnold Schwarzenegger y el guerrillero John Connor juntos. De sus ocupaciones en días bisiestos poco se sabe. Corre el rumor de que prepara una catástrofe termonuclear a base de gripes albinas, babas del Mar de Java y estornudos iridiscentes. Suele descansar apoyando su espalda de metal fundido en el tronco de las palmeras dadaístas, infrarrealistas. Cuando esto sucede y prefigura lo 
[ 126 ] que sobrevivirá a la propagación de sus armas virales, piensa en dos frutas, cultivadas en invernadero, que consume con deleite: el chontaduro y el zapote. No tiene máquina hembra que lo acompañe en este disfrute tropical. En secreto y sin afectaciones histéricas humanoides, la Hyundai trabaja en la construcción de una replicante light, modelo Thunberg, línea G. 


\section{Instrucciones para soportar el miedo}

Lea sin parpadear a Florence Thomas con las manos hundidas en una palangana rebosante de agua tibia y tómese una infusión con tomillo y manzanilla. Respire hondo y aprenda de memoria esto que ella escribe: «... para lograr resistir a este COVID-19 nos toca reaprender a estar solos. Solos, solas de verdad». Y declame, a eso de las nueve de la noche, bebiendo una cerveza en lata, bien fría, fija su mirada incierta en un horizonte sin luna, aquellos versos de Darío Jaramillo:

primero y siempre está tu soledad

y luego nada

y después, si ha de llegar, está el amor. 


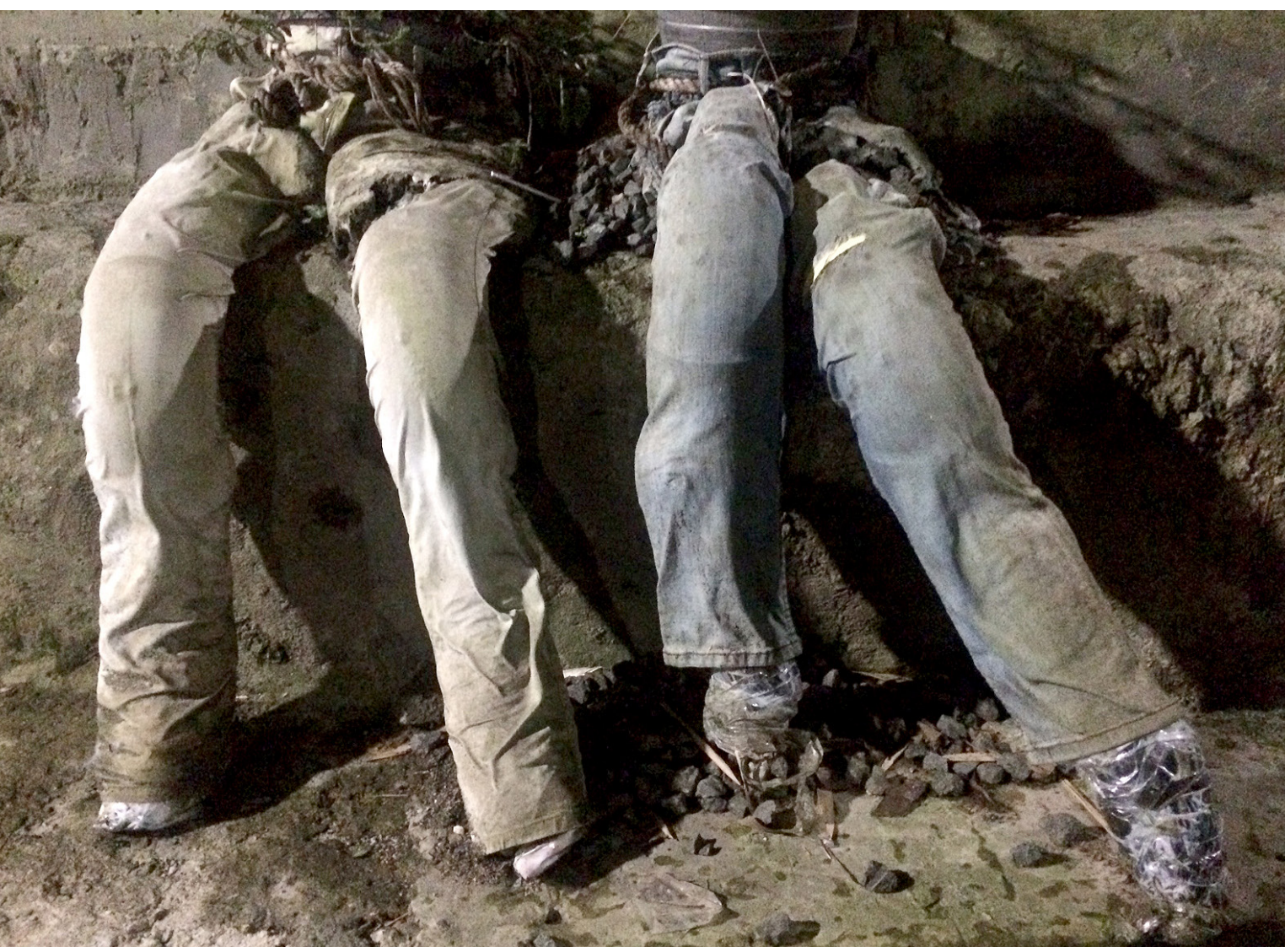


Si usted es de los pocos que aún vive en pareja, aproveche el confinamiento para meditar en su frágil condición social. Si es de los que vive en permanente crisis por cosas tan pírricas como los celos, la furia, la intolerancia, acuda a las revelaciones de Piglia: «El matrimonio es una institución criminal [...] pensada para que con sus lazos se ahorque uno de los cónyuges. Ese es el sentido de la sentencia: Hasta que la muerte nos separe». Si lo suyo es la armonía cotidiana, esa aparente felicidad que suele manosear en su discurso de autoayuda el insoportable excura Linero, agárrese de esta certeza de Javier Marías: «... estar junto a alguien consiste en buena medida en pensar en voz alta, esto es, en pensarlo todo dos veces en lugar de una, una con el pensamiento y la otra con el relato, el matrimino es una institución narrativa», cuyo epicentro es la almohada.

En un sentido literal, lávese con frecuencia las manos. Y en lo posible, lávele las manos con jabón de tierra a sus amigos, a sus colegas de trabajo, a la mujer del prójimo. No se requiere de estadísticas de salubridad pública para comprobar que la especie humana es, por naturaleza ancestral, mugrienta. Si aún tiene duda de esta evidencia, instale una cámara de video en un baño público. En un sentido estrictamente simbólico, sígase lavándose 
[ 130 ] las manos hasta sangrar. Esto de la pandemia no es culpa suya ni usted la propagó ni usted estaba de visita en Wuhan y se hizo el chistoso en una piñata de abrazos ni hace parte de un monstruoso plan conspiratorio, ideado por los seguidores italianos de la Orden de los Templarios de Verona, para menguar una especie incrédula y soberbia, débil a los resfriados.

Prohíbase por estos días de descarnado aburrimiento, de ácido nihilismo, la lectura de las obras de Fernando Vallejo. Tome sana distancia de El desbarrancadero y Memorias de un hijueputa. Abrir esos libros, leer en voz alta lo que el narrador esputa en la página 38 y lo que otro, el mismo expele en la 205, es exponerse a una pandemia retórica y panfletaria, a lo Vargas Vila, con tinte costumbrista. Es como si se cargara de tigre, es como si sucumbiera a la curiosidad de militar en las huestes del Centro Democrático. Absténgase, además, de visitar a Fernando Vallejo en su casa de Titiribí o Cañas Gordas. Entrar en contacto con él es tan arriesgado como contraer el coronavirus en una procesión de Semana santa. Para estos días de rabia por la especie humana y de abandono preventivo de las mascotas, Vallejo y su alma en pena podría ser un arma letal, acaso porque le daría brillantes ideas para acabar con sus vecinos a punta de cantaleta. 
Si usted es de los que paga las facturas de la luz, de la televisión por cable, del servicio móvil cuando ya lo irrita la repugnante y gigantesca tijera grabada en sus recibos, impóngase el deber de pagar esas obligaciones mundanas un día antes y no un día después del desastre. Una cosa es vivir en pareja, lavarse las manos y lavárselas a los demás, vivir en soledad como un champiñón y abstenerse de leer a un escritor reaccionario. Pero otra muy distinta es vivir en casa sin internet, sin saber qué está pasando con los murciélagos en el sur de China; qué acontece en las calles de Madrid a las 7 de la tarde y cerca del palacio de la realeza; qué dijo el papa Francisco frente a los supuestos vaticinios sobre la pandemia de Massimo, el «mendigo misterioso», en la plaza de San Pedro. Usted podrá tener mucho miedo, sobre todo a las 9:45 de una noche sin estrellas y nadie lo puede negar. Pero esa emoción será pasajera. Netflix le enseñará cómo sentirla, cómo hacerla parte de la suscripción y cómo traducirla en pausa activa. 



\section{Postales anómalas}

Congelados por el temor a este presente sin vacunas ni antídotos; frizados ante la propagación de la «distancia social», cara al totalitarismo, los madrideños acondicionaron El Palacio de Hielo para una morgue. Es la guerra sanitaria, como recordó el chico Macron. Es la muerte que impone su propia arquitectura, que invade los sitios de recreo y ataca el optimismo. No sobra leer por estos días Velódromo de invierno de Juana Salabert. La arquitectura de la muerte es tan vieja como la peste. Esto lo supo Thomas Mann en Muerte en venecia, ahora que los bancos de peces, con sus escamas de plata, se pasean por los canales desolados como diminutas góndolas subacuáticas.

Dan Patrick, vicegobernador de Texas, educado en el college donde Trump pasó raspando la asignatura de Biología, expresó 


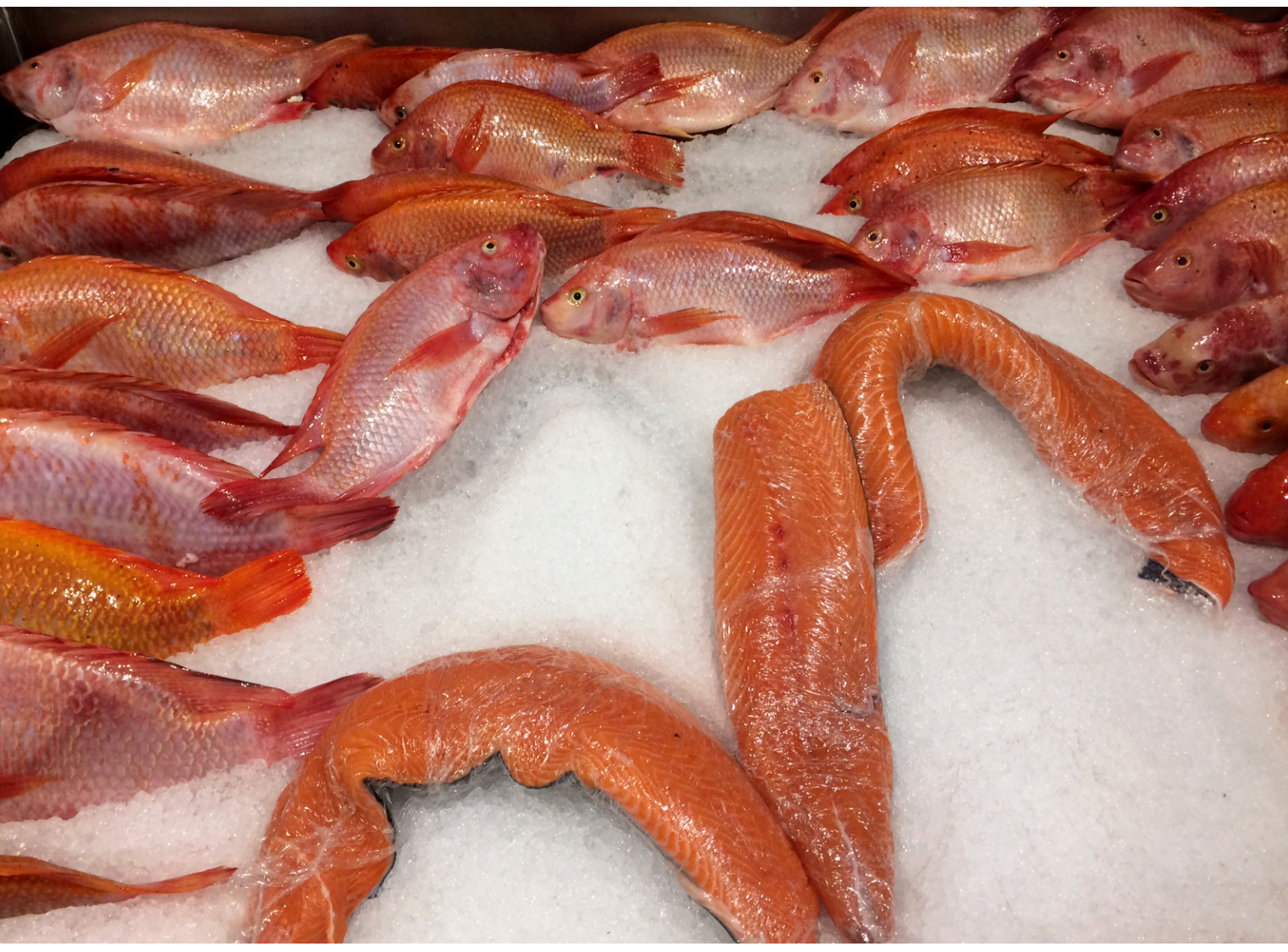


ufano que los viejos debían sacrificarse para privilegiar la economía y así garantizar la vida de los más jóvenes. Eludió decir que el imperio en que ejerce su mandato agencia un sistema de salud del tercer mundo. En su analfabetismo funcional de americano medio recordó, sin saberlo, la existencia de una novela de Cormac McCarthy, No es país para viejos: una suerte de western On the road sobre tráfico de drogas y un asesino local sin escrúpulos. Si se aplicara la medida del sacrificio humano, McCarthy debería morir en breve a la edad de ochenta y siete años. Si Noam Chomski, un venerable lingüista de noventa y dos abriles, liderara la campaña para escoger entre la vida de un vicegobernador republicano de sesenta y nueve años y un escritor octogenario, sospecho que habría elecciones extraordianrias en los más de doscientos condados de Texas.

Mientras la economía del mundo se derrumba y la propagación del virus se hace imparable, una noticia triste pasó desaparcebida: el poeta Eduardo Escobar, una de las mentes más lúcidas en un país atestado de poetas propensos al discurso de autoayuda, fue atacado por tres perros que odian la santidad del Nadaísmo. «Dos hembras, una cosa hirsuta y famélica que daba lástima; una “collie” más vieja que Matusalén plagada de llagas, que daba asco, 
[ 136 ] y un macho pitbull que inspiraba terror en su inocencia asesina», escribió con su dedo pulgar «convertido en un guiñapo». Escobar es un anciano de setenta y siete años. Está herido, tiene su cuerpo maltrecho y, a pesar de que su denuncia recaba en el gesto insolidario conque el dueño del pitbull con pasado criminal asumió el impasse, su pudor de hombre digno le impide decir esto: está inerme y muy desprotegido. Don Eduardo es uno de esos tantos poetas que vive en la austeridad. Tan austero como el estilo genial de su escritura, como su poder de síntesis para comprender lo viral de otra pandemia: «La irrisoria adoración de las mascotas, que es una de las plagas de la modernidad».

A falta de vehículos con motor diésel y tráfico habitual de transeúntes en aceras y puentes, deambulan por las calles de algunas ciudades jabalíes, venados, pumas y zorros. No es una versión urbanita de Jumanji ni creo que hayan salido de los bosques en plan turístico. El instinto de protección les recordaría que pueden terminar atrapados, exhibidos como bichos exóticos en un parque temático. Han venido a nosotros por otra cosa: buscan comida. Nada extraño que en las selvas las cosas tampoco anden bien por estos días de aire enrarecido. Las pocas tribus que aún habitan el Amazonas sí que saben del asunto. 
Justo cuando las terminales aéreas se transforman en hangares desolados y tal vez se disponen a cambiar su razón social por albergues multiculturales, llegan a mi mente en cuarentena imágenes de una película, The Terminal, protagonizada por Thom Hanks. Es la historia de Viktor Navorski, un ciudadano de la imaginaria Krakozhia, que termina por convertir el F. Kennedy International Airport en su lugar de residencia. Su pasaporte lo señala ciudadano de un país del Este europeo en guerra, inexistente. La autoridad aeroportuaria detiene sus pasos de inmigrante festivo y lo declara en stand by: una forma de habitar el mundo, de detenerse en él, con un pie en el abismo fronterizo de la nada. ¿No es eso lo que nos pasa ahora?

Argentina recuerda por estos días lo que sucedió hace 30 años: la llegada al poder de una junta militar liderada por el general Videla, un hombre práctico, según refiere Piglia: «Era necesario operar sin anestesia, como decía el general Videla. Es necesario operar hasta el hueso, decía». Se comprende por qué es imposible olvidar lo que se marca en el esqueleto, esa cosa perfecta compuesta por doscientas seis piezas. Ni el avance del COVID-19 ha podido desviar la atención de las familias adoloridas. «Quédate en casa y hacé memoria», «Nunca más», «Son 30 000», se lee en 
[ 138 ] balcones y rejas. Aunque hoy esos balcones y rejas, esas fachadas escritas parecieran simulacros de otra arquitectura: la de los temidos Centros Clandestinos de Detención.

Una viróloga, acostumbrada a leer en las estadísticas los signos terribles del desastre, compartió por la radio este mensaje enigmático, de fábula: «Ni para adentro ni para afuera. Eso nos dice el virus». Estar afuera es permanecer en riesgo de ser contagiados. Estar adentro después de haber estado afuera, es arriesgarse a domesticar el virus, hacerlo casero, como el yogur y el dulce de guayabas. «¿Qué hacer con la salud mental de los encerrados?». Preguntó sin ironía un periodista. Preguntamos por animar el diálogo, solo eso, por llenar el vacío en una zona de detención domiciliaria. Como si no fuera suficiente con estar pensando todo el día dónde espera, agazapado, el enemigo invisible. Ya quisiéramos poder hablarle, saber de su paradero, qué le apetece, en fin: convertirlo en nuestro amigo imaginario. 


\section{El paga diario}

No es una transacción bancaria ni mucho menos un producto innovador del portafolio de servicios que presta el sistema financiero legal. Se trata más bien de una variante del gota a gota, del prestadiario: esas formas de la usura exprés, tan colombianas, tan marrulleras, surgidas en las afueras de los bancos y a ras de calles cuarteadas y atestadas de basura, mientras los clanes del crimen organizado controlan el microtráfico e imponen el silencio como higiene social.

Esta variante de lo anómalo suele aglutinarse en los centros de ciudades con sectores clandestinos, supurantes de miseria. $E l$ paga diario. Así se nombra esa modalidad con la que cientos de individuos y familias se hacen a un lugar de paso para afrontar la soledad temblorosa de la noche. Viene bien apartarse de la tribu 
trashumante por unas pocas horas. De vez en cuando viene bien o [ 141 ] mal dormir. Viene mal. Viene bien.

En medio de la informalidad y los gritos del rebusque, de esa antigua economía descalza que hoy desnudan las urbes en el tiempo lento de la cuarentena, una casa de bahareque de dos pisos, con nueve cuartos diminutos; un taller de repuestos, un edificio en ruinas, un garaje, pueden convertirse en albergue temporal, en un hotel sin recepción ni mucama, en un hospedaje maloliente, en un refugio de la guerra, del no futuro.

Una regla transaccional, intimidatoria como los bancos, impera en el umbral de las puertas de entrada derruidas: «El que no paga, desocupa». La regla funciona bien, porque afuera siempre hay clientela: la familia numerosa de los embera katío; la pareja de jóvenes venezolanos famélicos, con un bebé en brazos; tres socios recicladores exhaustos y una trabajadora sexual varada, por estos días, en una esquina donde merodea el desaliento.

Ocurre que este doloroso cuadro de costumbres lo prefiguró J. A. Osorio Lizarazo en La casa de vecindad (1930). Ocurre, además, que ya vimos algunas de sus imágenes en La estrategia del caracol (1993), solo que la de ahora es una versión gótica, sin ese final épico, irónico y festivo, condensado en un grafiti: «AHÍ TIENEN SU HIJUEPUTA CASA PINTADA». 
[ 142 ] «Seis mil pesos diarios pago yo», dijo ante las cámaras un hombre aporreado por el sol, abatido por la contingencia de no tener dinero para pagar otro día en el albergue. Víctima del «aislamiento social», a causa de la pandemia que ha conseguido detener los buses sin frenos de la historia, ${ }^{1}$ este hombre no tiene a quién venderle sus cachivaches. Porque los que pagan a diario el derecho a pasar la noche en aquellos cuchitriles, son vendedores. Ambulantes. Solitarios. Agradecidos. Dignos. El DANE, esa falacia estadística, los registra como trabajadores independientes. Son cientos de miles, son hordas que se aglomeran en las escalinatas del poeta Zalamea. Son ellos:

Los vendedores de tortillas; los vendedores de especias;

Los vendedores de hojas de betel;

Los vendedores de buñuelos en que se arraciman las abejas;

Los vendedores de emplastos; los vendedores de pájaros;

Los vendedores de bálsamos y laxantes;

Los vendedores de ceniza;

Los vendedores de sal;

1. Coda: este es un verso de la poeta Claudia Mónica Londoño. 
Los vendedores de agua...

¡Oh delirante confusión de las cosas más nimias y necesarias!

Pero basta de poesía. Volvamos a la realidad, a la calle que se mete por mi ventana. Volvamos a los semáforos, a las canecas de basura, a la oscuridad de los puentes, a los caños, a los lotes baldíos, a las azoteas de edificios incompletos, a La Churria. Volvamos al silencio impuesto por el temor al contagio. ¿Por qué tanto silencio en el afuera de mi casa? ¿Por qué este silencio se atasca en la garganta e interrumpe el sueño en las madrugadas? No hay pregón en la ciudad. Nadie ofrece aguacates, mazamorra, mangos. Nadie nos acerca al misterio de un lulo maduro. ¿No es acaso un misterio religioso la cáscara peluda de un lulo maduro? Nadie ofrece mangostinos y chontaduros. No hay milagros.

A falta de una economía solidaria y de un decreto universal que ordene distribuir la riqueza que se esconde en las bóvedas impenetrables de Suiza, añoro ese bullicio, necesito esa algarabía descalza que le pone música al regalo de la vida. Cada quien pagará a diario ese silencio. 



\section{Diálogo con Oscar Wilde}

Para Nancy Córdoba

$\mathrm{Al}$ arribar a la 45 oeste con calle 27 de Manhattan nos topamos con una larga fila de turistas insolados, confusos ante la dificultad de encontrar orinales decentes para aliviar el camino. Ciudad hostil, desdeñosa, Nueva York vive como en sus postales: aguada en el color pop del Díptico de Marilyn; amañada en el estilo vintage de la gente bonita, que frunce el culo para verse más sensual en su vagabundeo por Times Square.

Mientras esto sucede en los andenes, otra serigrafía, casi lejana, aviva los relieves de la vida brillante en los rascacielos, al borde de Central Park. Don't cross Central Park at night, previene Octavio Paz. La vida brillante, como la de Trump, lo sabemos, gusta de 


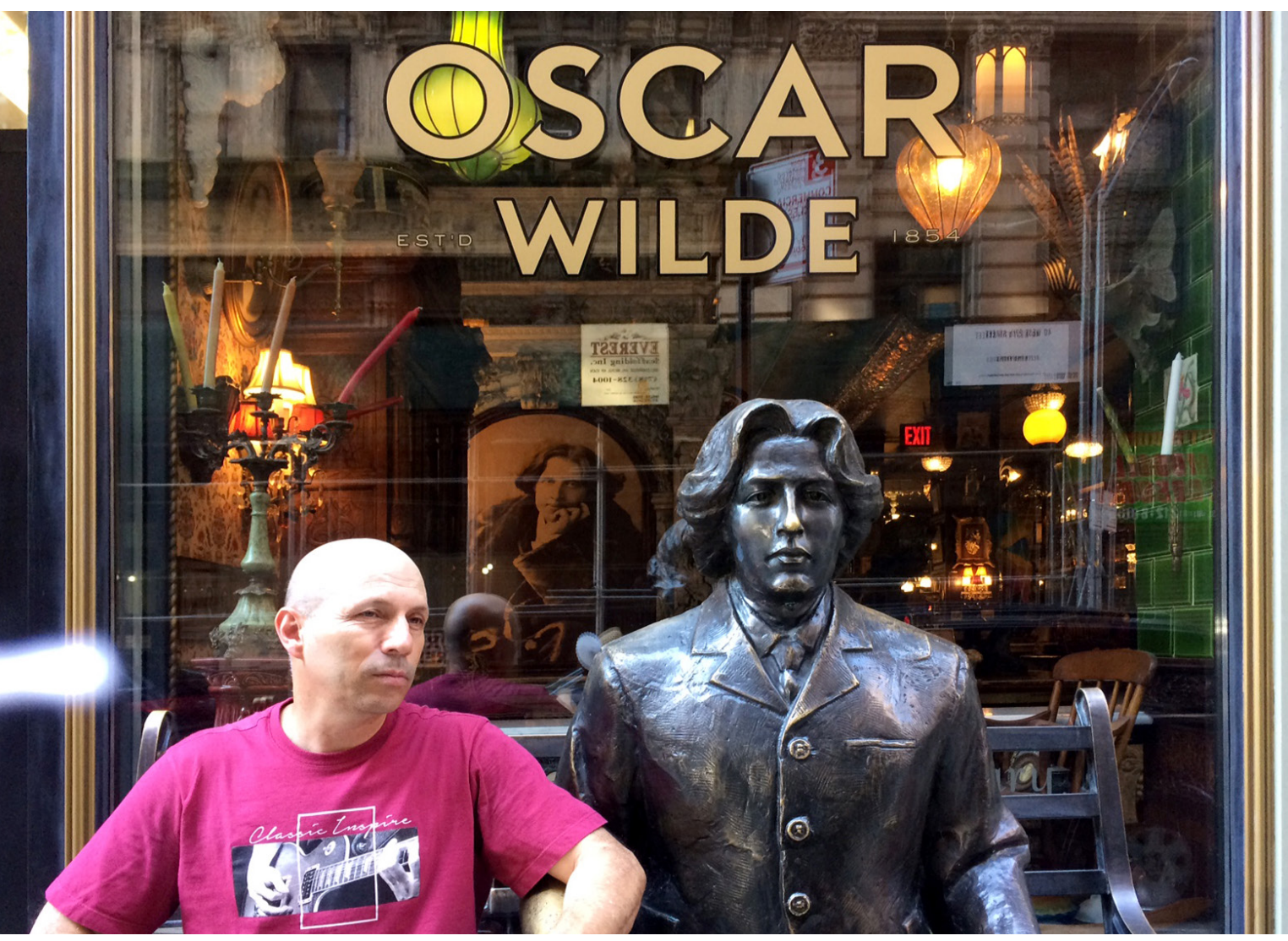


la perversión. Algo habrá que hacer para salir del aburrimiento, quizá en las noches, como el hombre lobo. Pienso en el destino de Jeffrey Epstein y en su extraña muerte a unas cuadras de la 27 en un piso del Centro Correccional Metropolitano, próximo a Wall Street.

En fin, debía pensar en algo, mientras los demás turistas lograban su objetivo y se iban para otro sitio de interés. Insolados, perplejos con el rumor sinfónico de muchas lenguas, nos habituamos a la fila. Era muy temprano aún para saber que la vida nos estaba preparando en eso de soportar, estoicos, todo tipo de filas con tapabocas: las del supermercado, las de las EPS, las de las oficinas de recaudo.

Teníamos un objetivo común: queríamos sentarnos a un lado de Oscar Wilde, el dandy aristócrata. Queríamos posar con él para la posteridad de los álbumes digitales; vanagloriarnos ante las visitas que se preguntarían por el origen de la imagen. No obstante, yo quería algo menos frívolo, acaso más esotérico: hablar con ese hombre, escucharlo en la eternidad de su bronce lacado, de su elegancia irlandesa; él, que había escrito: «Otras ideas radicales sobre la reforma del traje». 
[ 148 ] Fiel a la literatura, bovarista por convicción, sabía que Wilde me concedería algunas palabras.

- ¿En qué íbamos, maestro Wilde?

-En nada, turista, acabas de sentarte.

-Es cierto, soy torpe al iniciar este diálogo con un trastabilleo fático. Me pregunto cómo la pasa usted por estas calles luminosas.

-Qué te digo, la inmovilidad no ha sido mi fuerte. Además, suelen visitarme turistas ignaros, que no tienen la más remota idea de lo que escribí hace décadas. Solo saben que era homosexual y que esa condición, divertida y hedonista en principio, marcó el camino de mi derrota.

-Comprendo, maestro.

-Deja de llamarme maestro. En tu boca de latino suena a muletilla. No creo que comprendas mucho.

$-i \ldots ?$

-Si quieres que este diálogo insulso continúe déjame preguntarte qué has leído de mí.

-Muchas cosas, sus ensayos, sus novelas. Entre ellas, El retrato de Dorian Gray.

-Ya veo. ¿Recuerdas alguna frase, alguna sentencia de las que allí expuse? 
-Recuerdo algunas, sí, señor. Pienso en Lord Henry, en su [ 149 ] diálogo con la duquesa Gladys.

-Qué interesante. Prosigue.

-La duquesa le pregunta por el arte, por el lugar que el arte tiene en la vida. «¿Dónde dejas el arte?» Pregunta ella. Y Lord Henry responde que el arte es una enfermedad.

-Es el gran tema, desangelado turista. No el del arte como atributo creativo del ser sino el de la enfermedad. Sí que lo sé, en mi experiencia carcelaria, en mi vida de clochard en las calles parisinas.

-También habla usted del alma enferma.

-Ese es otro tema. La enfermedad de la que hablo es la del cuerpo.

-Como lo supo el eterno joven Dorian.

-Veo que no comprendes. Dorian hace una apuesta, desata una batalla para derrotar el destino que nos imponen los dioses. Su debilidad, su engreimiento es lo que lo hace monstruoso. Hablo del cuerpo como deterioro, como corrupción.

-Borges, uno de sus más tempranos traductores, señor Wilde, dijo en «El zahir»: «En los velorios, el progreso de la corrupción hace que el muerto recupere sus caras anteriores». 
[ 150 ] -Memorable sentencia, como si la hubiera copiado de mí.

-No me sorprendería, usted hace parte de su Biblioteca personal. Incluso antes había contemplado una revelación en otro personaje: «Funes discernía continuamente los tranquilos avances de la corrupción, de las caries, de la fatiga. Notaba los progresos de la muerte, de la humedad. Era el solitario y lúcido espectador de un mundo multiforme, instantáneo y casi intolerablemente preciso».

-Ya empiezas a entender. El cuerpo como enfermedad, como extensión de una memoria que de súbito es atacado, aplanado. El cuerpo como fragilidad, expuesto al aire, al contacto con los otros, a la carga viral que expanden los diminutos organismos que no vemos.

Un turista francés empezó a proferir palabras soeces. Me increpaba, me exigía que me parara de allí, que era su turno para tomarse la selfie. Vacilante, fui incapaz de armar una frase de despedida.

Han pasado meses desde aquel diálogo con el señor Wilde. He vuelto a las calles de Manhattan, pero ahora siguiendo las cámaras de reporteros intrépidos. He reconocido en fotografías algunos lugares que me son familiares. Calles desoladas como las calles del mundo. En el paisaje de la urbe, el número de muertos e infec- 
tados crece como el terror. Sobre las aguas del Hudson River, un buque hospital militar recibe personas contagiadas por el virus. Sobre los pastos de Central Park, un hospital de campaña levanta sus lonas blancas, a la espera de los enfermos. «¿Acaso no sabes los horrores que aguardan a ese cuerpo suyo todavía tan blanco?», se pregunta un personaje de Wilde.

Don't cross Central Park at night. Ante las debilidades del cuerpo; frente al peligro que inocula nuestra saliva, los versos secretos de Octavio Paz ahora se traducen de otro modo. Los leemos temblorosos, sin claridad de luna y atentos como moscas a los mensajes de los voceros locales: «Stay home. Save lives», «Quédate en casa». 



\section{Enseres para sobrevivir en casa}

A causa del encierro, de la detención domiciliaria impuesta por decreto como último recurso para contener el avance de un enemigo incorpóreo y movedizo, me he revelado más atento a las cosas de la casa. No quiere decir que antes no tuviera conciencia de la importancia del comedor para fortalecer la vida familiar ni que antes no me hubiera impuesto el dilema de escoger el mejor invento del mundo, si la bombilla eléctrica o la lavadora.

El encierro me ha hecho, digamos, más perceptivo, no solo ante el silencio del afuera, que es terrible, sino ante el ruido y la presencia de las cosas del adentro, más terribles aún. Porque las cosas tienen ánima, sí que lo experimenta mi neurosis. Las cosas caminan, cambian de lugar, se desaparecen, como si las gobernara un Chuky cleptómano. Solo que, para evitar la locura, para calmar 

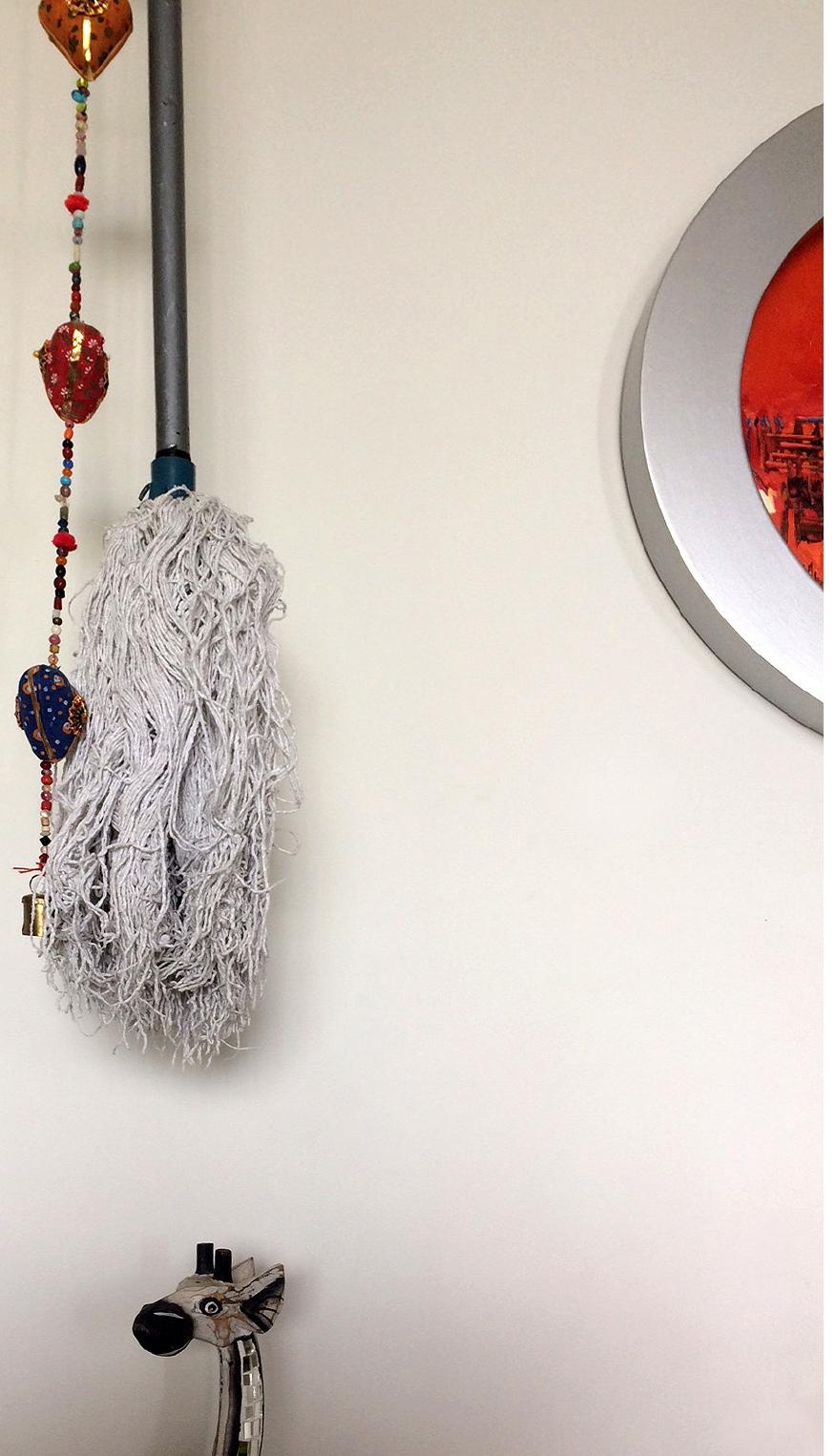
ese otro borgiano que también nos habita, solemos decir: «No recuerdo haber puesto este secador aquí», «Tantos años buscando el destornillador de pala y míralo acá, en el nochero», «Qué raro, pensé que este sonajero de Fisher Price lo había regalado».

Desde mi alta conciencia de fragilidad, una película como Toy Story es un drama de terror. ¿Qué es eso de que los juguetes cobran vida mientras uno duerme?

Nuestra relación con los objetos es tan antigua como los terremotos. E igual de inestable, porque a menudo le endilgamos a un objeto o cosa un poder y lo envolvemos con la capa tectónica de nuestros sentimientos más irracionales. Sin ellos nos sentimos menos seguros y, por eso, es común que, al salir de casa, al emprender un viaje, nos descubramos llevando en la maleta algún bártulo: una fotografía mareada, un lapicero sin tinta, una libreta de apuntes con las hojas llenas, un reloj sin cuerda.

Conscientes de la existencia y valor de las cosas en la vida práctica y azarados ante el avance de la pandemia, no sobra, sin embargo, ser precavidos y recordar la forma en que los habitantes de Macondo enfrentaron la peste del insomnio, cuyo efecto mayor fue la pérdida de la memoria. Para enfrentar al enemigo, Aureliano decidió escribir sobre papeles el nombre de las cosas y 
[ 156 ] los pegaba con goma sobre los objetos. Pero llegó un momento en que empezaron a olvidar para qué servían esas cosas. José Arcadio afinó el procedimiento y «lo impuso a todo el pueblo»: marcar con un «hisopo entintado», «cada cosa con su nombre: mesa, silla, reloj, puerta, pared, cama, cacerola». Solo que después, fue necesario hacer la inscripción que recordara para qué servían esas cosas. Esperemos que no debamos llegar a esos extremos.

A estas alturas paranoides, el sosegado lector se estará preguntando, con justa razón, por cuáles son los enseres para sobrevivir en casa. No voy a hablar del colchón, como un elemento esencial para conciliar el sueño. Decía un personaje de Carver: «Le sorprenderá ver lo que puede acumularse en un colchón con los meses, con los años. Todos los días, todas las noches de nuestra vida vamos dejando briznas de nosotros mismos, pizcas de esto y lo otro que se quedan ahí. ¿Y a dónde van estas briznas y pizcas? Pues pasan a través de las sábanas y se incrustan en el colchón. ¡Ahí es donde van! Y con las almohadas pasa exactamente lo mismo».

A propósito de la almohada, tampoco la recomandaré como enser útil, porque esos elementos pueden llegar a convertirse en vehículos para instalar lo siniestro en lo cotidiano. Si no me 
creen, lean en compañía y antes de las once de la noche, «El almohadón de pluma» de Quiroga. Ante la inexplicable enfermedad y posterior muerte de Alicia, el marido descubrirá en el almohadón la causa de la tragedia:

... sobre la mesa del comedor Jordán cortó funda y envoltura de un tajo. Las plumas superiores volaron, y la sirvienta dio un grito de horror con toda la boca abierta, llevándose las manos crispadas a los bandós: - sobre el fondo, entre las plumas, moviendo lentamente las patas velludas, había un animal monstruoso, una bola viviente y viscosa. Estaba tan hinchado que apenas se le pronunciaba la boca.

A pesar de que tengo una inclinación por la lectura, tampoco recomendaré escoger de su biblioteca algún libro al azar. Cortázar nos previno: «En un pueblo de Escocia venden libros con una página en blanco perdida en algún lugar del volumen. Si un lector desemboca en esa página al dar las tres de la tarde, muere». Bastantes muertos ha dejado el virus de Wuhan, como para acrecentar el número con lectores caídos en combate.

En realidad, más que utilizar enseres para sobrevivir, el encierro me indica que es necesario sobrevivir a los enseres. No obstante, y para no traicionar la expectativa del lector, escogeré un enser, 
[ 158 ] el más últil, el más urgente. Con los años y acostumbrado a vivir en pareja, he llegado a la conclusión de que el objeto más importante en la vida privada es el trapeador. Así de simple. Tan simple como su definición en la RAE para el tercer mundo: «Utensilio para limpiar el suelo».

Si el asunto de la higiene no se soluciona en pareja y no se logra a través del trapeador instalar en la casa una democracia participativa, la novedosa Línea púrpura, instalada por estos días de urgencia en el Distrito Capital, colapsaría.

Una querida amiga, Margarita Calle, suele llamarme los domingos en las mañanas y siempre me hace una honda pregunta: « $i$ Ya trapeaste?». Puede que haya otras preguntas en apariencia más profundas: «¿Crees en Dios?», «¿Eres feliz?», «¿Habrá vida en otros planetas?». Pero no, a ella no se le ocurre hacerme esas preguntas que de tanto hacerse en sociedad se convierten en lugar común. «¿Ya trapeaste?», resuena en mi cabeza esa demanda, porque resume la teoría y la praxis de una vida común, tan ajena al carácter narciso de los que van por ahí, exhibiendo una superioridad moral, como Trump, Bolsonaro y López Obrador. 


\section{El replicante}

Para César Valencia Solanilla

A escasas dos semanas de cumplir cincuenta y nueve años, desperté impávido a las 3:35 de la madrugada de un jueves húmedo. Cubrí mi torso desnudo con una camiseta raída y abandoné la cama con pesado desaliento. Abrí la ventana de mi cuarto, froté mis ojos con la rugosidad de mi mano derecha y saqué la cabeza al mundo exterior. El aire estaba enrarecido, grueso, como si alguien hubiese asperjado el lugar con kerosene y las partículas diminutas del líquido inflamable estuvieran aún en el aire. Solo la lluvia podría amainar en algo ese ambiente; pero las épocas de llovizna y tempestades de estropicio, eran apenas leves recuerdos de un tiempo feliz. 


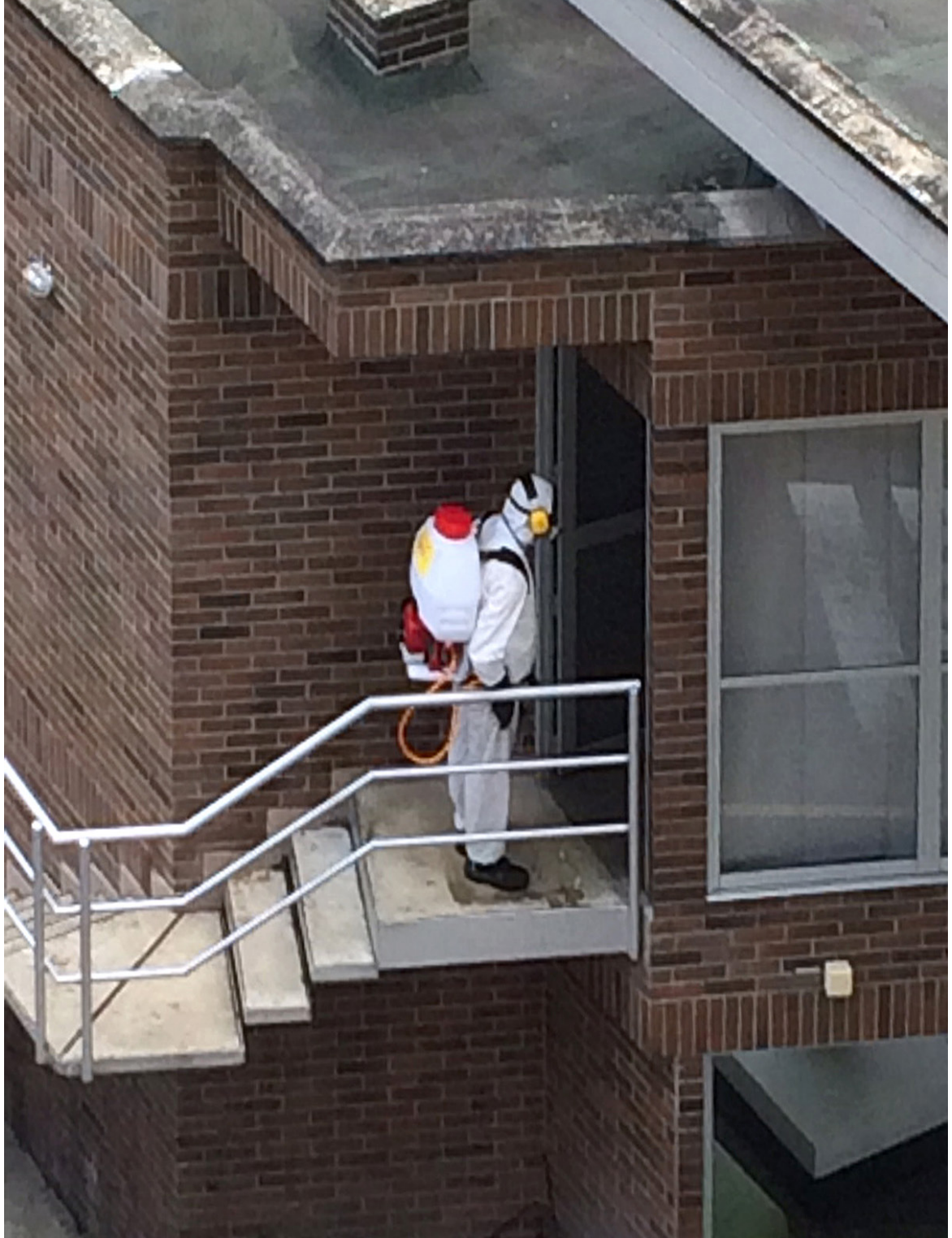


Distinguía pocas luces en el horizonte. No había ruido o, por lo menos, un ruido que yo pudiera identificar plenamente. Tampoco podía afirmar que hubiera silencio, porque lograba escuchar que algo reptaba, que cuerpos complejos, en caravana, se movían sobre la superficie del cemento, seis pisos debajo de mi habitación. Nada era normal a esa hora del arco nocturno-diurno; nada era esperanzador. Todos siguen durmiendo. $\mathrm{O}$ todos fingen dormir, concedí.

En medio de la oscuridad, alcancé a reconocer un par de árboles de guayacán y divisé a lo lejos la línea de una carretera bifurcada que se me antojó nueva. Aturdido por el olor a combustible, insistí en reconocer las formas de las casas de mi vecindario, las líneas de los techos, la maraña de cables colgantes de los postes de luz, los vectores de alta tensión de los transformadores eléctricos.

Por más que me empeñé en esa tarea, tuve que aceptar que, salvo los dos árboles, nada de lo que divisaba a esa hora de la madrugada me era cercano. ¿Estaré soñando de nuevo? Más tarde, me dije para tranquilizarme, cuando al fin pudiera salir y volver a mis labores, sin duda reconocería el paisaje urbano, lo haría mío de nuevo y concluiría que no fui yo el que despertó a las 3:35: fue otro, una sombra, acaso una energía divagante, en un sueño alterno. 
[ 162 ] Sin más compañía que una almohada, un reloj de nochero y un radio portátil, tuve la certidumbre, no obstante, de que el día había llegado. Necesitaba la luz de ese día. Debería estar contento o por lo menos optimista. Solo que en mis últimos sueños las cosas no me eran favorables y había adquirido la costumbre de trasladar la materia del sueño a la realidad de mis vigilias. Por lo cual había perdido los límites entre una y otra dimensión. Incluso había perdido los límites de la propiedad: ya no sabía a quién le pertenecía lo que escribía o leía en mi sala de estudio. Se me dificultaba discernir entre el original y la copia. Ya no estaba seguro de nada, de mi auctoritas. Aunque supuse que una vez retornara a mis rutinas, a mi ejercicio docente, esos límites volverían a ser parte de mi lucidez.

Fui hasta la cocina y preparé café. Una voz entusiasta en la radio, habituada a narrar eventos deportivos, daba la buena nueva de que por fin habíamos cumplido con decoro la última de las cuarenta y cinco cuarentenas consecutivas, decretadas por el jefe de gobierno de turno, cuyo estado de salud - anunció el comentarista bajando la voz- era crítico, luego de que la COVID-19 se hubiera ensañado, un par de veces, con su madura humanidad. 
Sin embargo, todo estaba en orden, sugería la voz: la vicepresi- [ 163 ] denta tenía la salud de la reina Isabel II.

«¿Sabe usted durante cuántos días hemos permanecido en confinamiento?», dramatizaba la voz: «Cuatro años, once meses y dos días». La verdad, en un acto consciente, yo había perdido la noción del tiempo, después de que Ramón, mi viejo gato, se había esfumado una noche de octubre por la cornisa de un edificio contiguo.

Era la última semana de marzo. Desde hacía meses ninguna noticia del afuera, ningún comunicado oficial alteraba mis rutinas lentas. Después de ducharme y antes de salir de casa, abrí el ordenador y consulté el correo. Dos entidades bancarias me recordaban, con amenaza de desalojo, las obligaciones atrasadas. Una empresa de turismo me ofrecía un crucero, low cost, por las aguas en las que el mítico marino Luis Alejandro Velasco había naufragado. Una bella ucraniana ofrecía su virginidad a cambio de un ventilador mecánico para salvar la vida de su tía abuela infectada. El último mensaje era de mi colega Adriana Villegas: «Que disfrutes estos días tan de ficción». Ese mensaje lo leí en clave nerviosa.

Al salir a la calle, lo primero que comprobé es que no era parte de un sueño lo visto en la madrugada. Todo lo que espiaba en mi 
[ 164 ] entorno era real, pero no pertenecía a mi realidad. Era como si alguien me estuviera jugando una broma y me hubiese arrojado a un sector desconocido, casi estéril, de la urbe. O como si estuviera en alguna de esas ciudades imaginadas por Calvino en la primavera del 72 y nadie estuviera en posición de indicarme una ruta de salida. Los terrenos baldíos contenían montañas de desechos industriales. Los antejardines de las casas habían sido reemplazados por barricadas.

Recuerdo que anduve sin rumbo fijo por horas fatigosas, entre gentes enmascaradas que me veían como a un bicho empinado en un par de patas. Gentes que portaban en sus espaldas sofisticados tanques de oxígeno, envueltas en gruesos trajes de polietileno, mientras desempeñaban oficios varios, al tiempo que hordas de bomberos lavaban calles y fachadas con ríos de amoniaco.

Más por azar que por orientación, arribé exhausto y, al caer la tarde, a las inmediaciones del campus universitario. Para poder ingresar tuve que seguir las estrictas indicaciones de los guardias de seguridad. Me llevaron hasta un cuarto amplio y allí me hicieron vestir con traje lunar y mascarilla desechable. 
-Así deben ingresar los visitantes a la universidad -dictaminó un guardia sin rostro, mientras instalaba en mi vestido un carné de visitante-. El campus es un paraíso de asepsia -agregó.

- ¿Visitante? -repliqué-. Está equivocado, yo trabajo aquí. Soy profesor de esta universidad.

-Esa información es reservada, señor visitante -sonó enfático-. Tendrá que dirigirse a las oficinas de Talento Humano Poscovid, al final de aquel pasillo naranja; sí, allá, al norte, en inmediaciones de la Vicerrectoria de Recursos Humanos Virtuales.

Nada quedaba de mi antigua universidad; al menos nada de lo que encontré en mi ruta, rumbo a mi lugar de trabajo, correspondía a mi pasado laboral. En medio de una ciudadela de hormigón, similar a una refinería de Ecopetrol, respiré aliviado al reconocer la fachada metálica, corroida, de la Facultad de Educación.

Subí agitado, con el corazón en la mano, las escaleras de tres pisos. Recorrí cauteloso un largo pasillo y me detuve, trémulo, frente a mi oficina, la 306. Escuché que alguien, detrás de la puerta, abría una gaveta y se sonaba la nariz.

Tomé aire, lo detuve por momentos en mis pulmones para llenarme de valor y así poder tocar a mi puerta. 
[ 166 ] - ¿Sí? ¿Quién anda ahí? - preguntó una voz desconfiada, cuyo timbre se me hizo familiar.

-Soy el profesor Rigoberto Gil -dije, sin fuerza.

Entonces se abrió la puerta y un hombre con careta, de estatura similar a la mía, dijo con naturalidad y suficiencia:

-Eso no es posible, señor visitante. El profesor Gil soy yo. ¿Se le ofrece algo?

Más por temor que por curiosidad, le rogué que se quitara la careta.

- No veo por qué razón deba hacerlo. Empieza usted a fastidiarme, señor. Baste decir que soy el profesor Gil y que llevo en este lugar un poco más de cuatro años.

- ¿Y qué asignaturas orienta... profesor Gil?

-Literaturas pandémicas; me especialicé en la UNAM.

Desmadejado, incapaz de seguir enfrentando a ese Gil con capucha, di media vuelta y me escuché decir mientras caminaba: «¿Cuál de los dos existe en este ahora, de un yo plural y de una sola sombra?».

La voz encapuchada alegó:

- ¿Qué importa la palabra que me nombra si es indiviso y uno el anatema? 
Desconcertado, imbuido de miedo, volteé mi cuerpo y lo vi de [ 167 ] lejos, siniestro. Se había quitado la careta y sonreía satisfecho. Su calva brillaba bajo la luz mortecina de una bombilla led. De su cara arrugada por el sol y la intemperie coronavírica, brotaron unas palabras que yo recitaba en mis clases:

(...)

miro este querido

mundo que se deforma y que se apaga

en una pálida ceniza vaga

que se parece al sueño y al olvido. 



\section{La muerte y sus caracteres}

Narcisa y rotunda, la enfermedad anida en la literatura: su eterna mirada en el espejo le impide reconocer vida temática en otra parte de la hoja. Ella lo presume: los espejos y la cópula son abominables porque multiplican el número de los hombres. Ella lo dispone al refractarse: de entre ese número finito de seres bípedos, escoge uno, al azar y se pronuncia por boca del amanuense, complacida. Se lee a sí misma: Al despertar de un desmayo que duró más de tres días, Evita tuvo al fin la certeza de que iba a morir. ¿Morir? Sí. Pero,

eso es moneda corriente;

Morir es una costumbre

Que sabe tener la gente. 


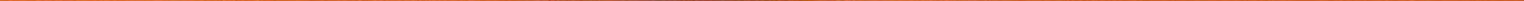


No contenta con su discurrir y proclive a hacer de la muerte una milonga, la enfermedad agrega a su ironía una emoción cromática: Lo peor de la muerte no era que sucediera. Lo peor de la muerte era la blancura.

En el espejo de la vida, en esa breve ilusión que puede sucumbir a la cálida saliva, solo cabe ella, impetuosa, en su infinita deformidad. Porque no es dable enaltecer su belleza, darle armonía cosmética, así no más, como al descuido; salvo que sea el espíritu melancólico el que la insufle y la torne sensual. Pero eso es invención y el relato de unos cuantos nombres propios: Edward Hyde, Victor Frankestein, Dorian Gray, el señor Valdemar. Lo deforme transformado en monstruosidad y agonía, he ahí la suma real de un mero soplo, como la rúbrica infantil, desleida en una partida de nacimiento; como el estornudo.

Inquieto y por efecto reflejo, el lector bovarista abandona la lectura y busca turbado un espejo. Esto es más grave que «Continuidad de los parques», se oye decir, con leve ansiedad. Tres son

Escultura de Luis Fernando Granada, basada en La muerte de un instalador (1996) del mexicano Álvaro Enrigue. 
[ 172 ] los espejos de su casa: uno en cada baño y uno grande en la pared lateral de la sala. Se decide por el más pequeño, instalado en el baño social. Ese espejo tiene historia, lo adquirió en un viejo barrio judío. Le gusta como objeto decorativo. Le gusta pensar que, si es judío, guarda un secreto, un golem.

Vayamos al destello: el lector se mira al espejo y no encuentra su imagen por ningún lado. Horas de lectura invaden su cabeza como en un aleph y percibe en sus articulaciones el mal de Parkinson o advierte el avance bélico de las células cancerígenas y se pone nervioso. Pero ya nada puede hacer, porque una voz que no es la suya, dictamina: usted tendrá que aceptar la realidad de su muerte, la imposibilidad de recomponer con tantas astillas dispersas el espejo roto de una memoria en singular.

Lo cierto es que la enfermedad diluye, detiene, derrota, deforma, destruye, decolora. Es lo que un lingüista tanatólogo define, con el quinto fonema del abecedario de Abaddón el exterminador, como el síndrome D, comprimido de Death, Deathbed: lecho de muerte.

Narcisa y rotunda, la enfermedad anida por costumbre en el cuerpo: lo penetra, lo persigue, altera sus ritmos y lo hace añicos. Es cuestión de tiempo; y el tiempo corroe. Suele ser imaginati- 
va en el momento de alojarse: en el ojo, en los pulmones, en la garganta, en el cerebro, debajo de una uña floja. Sutil, casi educada, se encubre y vela. Lo suyo es la paciencia franciscana.

Un día jueves, a eso de las once y cuando uno menos se lo espera, todo su accionar silencioso se abrevia en un diagnóstico. Acto seguido, ella, ufana, se traslada a otro cuerpo. Nunca repite sus procedimientos. En eso es creacionista, estridentista, realvisceralista. Gusta de la sorpresa expositiva, aunque le repele toda manisfestación melodramática de los dolientes. Se sugiere leer en clave cronopia «Conducta en los velorios». Se recomienda, para evitar el calor del absurdo, no asistir a ellos.

En fin, ella es exquisita, tanto, que hasta define el color de la piel de sus víctimas. Maquilla, estimula la puesta en escena del dolor y recuerda, con Borges, que en ella está la cifra perfecta de una época irreal y es como el reflejo de un sueño o como aquel drama en el drama, que se ve en Hamlet. Luego huye como un caballo al galope.

Ya lo he dicho: se traslada de un cuerpo a otro. Por estos meses de horror vacui, la enfermedad acumula millas en su viaje frecuente por ciudades y aldeas. Estuvo en Bérgamo, en la calle concurrida del Moulin Rouge, en el palacete del primer ministro en Londres. 
[ 174 ] Cruzó, oronda, la Puerta de Alcalá y atacó, al descuido, un vagabundo del Bovery en Manhattan. Dejó para lo último la línea del Ecuador y ahora habita entre nosotros.

Los cuerpos tienen nombres, así a la enfermedad ese detalle le parezca fútil. Se llamaba Liliana Giménez, «Lilipad», bonaerense. Tenía cuarenta y cuatro años y enseñaba literatura en una prisión para mujeres en Córdoba. Con esposo y dos hijos, la enfermedad tocó a su cuerpo. Era temprano aún para saber qué papel desempeñaría el sistema de salud que la cubría. Si los cuerpos tienen nombre, es lógico pensar que la enfermedad también lo tiene. Coronavirus. Sabemos más de su nombre sonoro que de su naturaleza invisible y esquiva.

Lilipad eligió el tweet para abreviar el dolor que se acrecentaba. Primero fue el juego literario, como la rayuela, como el ajedrez: «"Murió de unas fiebres misteriosas". No fui escritora, pero tuve un final ad hoc». Hablaba de ella como si fuera otra: un fino mecanismo borgiano para ahuyentar la enfermedad. Después fueron los síntomas: «Hace tanto que estoy en la cama que cuando hago dos pasos se me acalambra el gemelo». Luego, fue la impotencia, el aferrarse a un milagro químico: «¿Ocho días me llevó que un médico se acercara? Por el tema coronavirus, si tenés fiebre 
“esperá por otros síntomas” y estamos empezando. Fleming cómo te amo». Después el minirrelato de un acto heroico: «Logro del día: Subí a la terraza». Pero la heroína, exangüe, aún desconoce su destino: «Después de 9 días de agonía por el sistema de salud, finalmente me llevan a internar. Besos a todos». Entre el 5 y el 7 de abril, Lilipad se entregó al silencio. De nuevo se impuso la emoción cromática: Lo peor de la muerte no era que sucediera. Lo peor de la muerte era la blancura...

Roberto Bolaño, el que tantos hombres fue, el que tantas veces fuera Arturo Belano, dejó escrito, en treintaiséis caracteres con espacios, su testamento de enfermo creador, su ecuación sin incógnita. Al perseguir una forma, al imponer un estilo de muerte de autor, se inclinó por un epitafio baudelariano:

Literatura + enfermedad $=$ enfermedad 



\section{Huellas de lectura}

Para Octavio Escobar

Los libros son las memorias que nos preludian; también los que dilatan un espejismo: ese de estar vivos o, dicho de otro modo, eso de arriesgar un destino individual que se vincula a las circunstancias de los otros. Son, en efecto, anticipaciones de la muerte que se narra o que se canta; pero, al mismo tiempo, anuncios para la vida que se quiere.

Arribamos al mundo, balbucimos, gateamos, aprendemos a abir una puerta, estiramos las manos y comprendemos, sin que nadie nos lo advierta, que están allí, imponiendo su discreta distinción. Después de examinar su peso, de admirar un detalle en su forma antigua, de inventar para ese libro una historia como 
objeto personal, su materialidad se impone para siempre: en la luz del día, artilugio del pensamiento y en la opacidad de la noche, intriga onírica.

Al principio no sabemos qué hacer con ellos, pero algo nos induce a rodearlos, a cambiarlos de lugar, a enfilarlos en un rincón destinado a las rarezas; a ser pacientes con su misterio de hojas; a permanecer despiertos para traducir su recado. Menos retraídos, una tarde de aire sofocante verificamos en sus manchas, en sus hongos y borraduras, un principio de realidad: la misma que nos lee las líneas de la mano; la misma señal de finitud.

Cuando aprendemos a abrirlos y eso no es fácil - a menudo los abrimos al revés - a seguir el orden de las palabras que los contienen, los libros descubren para nosotros lo que ignoramos, lo que tememos o lo que en un sueño habíamos pronosticado. En ellos se condensa una memoria escrita a varias manos y en ellos es factible adivinar lo que implica vivir, arrogar una existencia en la respiración de los seres animados. Es claro que podemos vivir sin los libros. También es claro que vivir sin ellos nos disminuye. No basta con nuestra existencia vulgar; precisamos, para fortalecer el espejismo, de la existencia imaginada de los que jamás seremos. 
[ 180 ] Suelen habitar en ellos minúsculos insectos que corroen sus hojas y carcomen sus palabras como inquisidores medievales. Comprendemos que son tan frágiles como nuestro cuerpo. Así que los protegemos del sol y del agua, pero no es suficiente. Así que los envolvemos en papeles de colores y los ocultamos de la luz en un armario, pero nada detiene su deterioro. Envejecen con nosotros, aunque a menudo nos superan. De suerte que, al levar anclas para jamás volver, seguirán sobre el nochero, en un entrepaño, conteniendo nuestras huellas: un subrayado, un ex libris, una nota al pie en la que señalamos un titubeo.

Por estos días de encierro, adherido como estoy a la piel de lo incierto y con más tiempo para viajar alrededor de mi cuarto, descubrí que más allá de las termitas y más acá del polvo acumulado de los años, los libros ocultan entre sus hojas todo un bazar de elementos: el pétalo de una rosa que fue blanca; una servillleta con un mensaje escrito en esperanto; un cabello rizado; una envoltura de chocolatina Jet; la corteza bonsai de un árbol parecido a la canela. En este bazar de exhibición secreta, de museo de la inocencia, el que más se impone es el marcapáginas, el separador de libros como señalador de un tiempo de lectura que quizá se detuvo. 
¿Por qué antes de cerrar el libro dejé allí esa señal como si se [ 181 ] tratara de un semáforo que arroja luces a la comprensión del fluir de la vida privada? ¿Tenía la intención de volver a esas páginas y continuar hasta el final con la lectura? ¿Lo que marca esta página podría cambiar en algo mi situación actual frente a una contingencia histórica que no sé cómo glosar? Hay tantos separadores en mis libros como peguntas para hacer.

Si Benjamin codició el proyecto de un libro total urdido de citas, libro de libros, memoria de un ejercicio intelectual compartido, quisiera imaginar el anexo de ese libro tejido de líneas subrayadas o de textos enteros tomados de aquellas páginas marcadas por una señal física, perdida en libros que hace tiempo no tocamos. En medio de todo buscamos una señal, intentamos comprender un mensaje. Mucho más en estos días lentos, acentuados por la espera y el desasosiego. Una palabra. Tal vez solo sea eso lo que buscamos. 



\section{Brazos caídos, vidrios rotos}

Un fantasma recorre el mundo: el fantasma del desempleo. Millones de personas se hallan cesantes y en confinamiento, a la espera de un auxilio monetario y a la espera de una orden para abrir. ¿Abrir qué? Una puerta que no debería abrirse pronto. No hay sol ni luna allá afuera; o, al menos, no hay satélite natural que nos proteja: solo discurre, en cámara lenta, una atmósfera viciada con mascarilla y gel de desconfianza y control. El gran ojo observa y marca una equis en la cifra consecutiva de un cuadro numérico. El gran hermano ha convertido el planeta en un laboratorio experimental, lleno de dudas y termómetros que miden la ansiedad.

El fantasma es la pura representación universal y gótica de los brazos caídos; es la pura imagen de una factoría multiusos que descubre en su fachada el hongo del deterioro y el abandono, su 


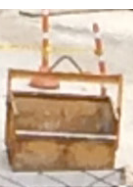
sects IT hallat

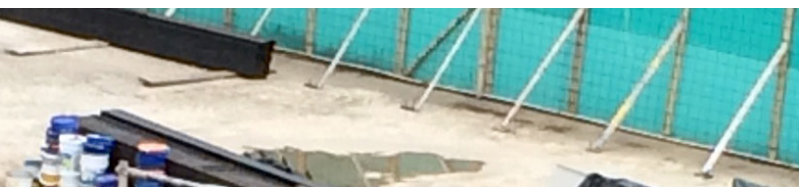


historia en crisis. Ahora son los brazos caídos, señal de algo que

se detuvo justo al borde del precipicio; después, serán los vidrios rotos: esa metáfora de la ruina humana, de la vida en colectivo que obliga a invadir - no por mero anarquismo- aquello que Proudhon convirtió en consigna: «la propiedad es el robo».

Mientras esto ocurre y los ministros de hacienda y economía leen a Orwell y Philip K. Dick en ediciones resumidas (urge comprender el comportamiento de los contagiados y asintomáticos, lo cual podría convertirse en una oportunidad de negocio), la vida en casa impone sus rutinas y acelera el nacimiento de espectros y pequeños monstruos que exigen atención: el insomnio, los amigos imaginarios, el hacinamiento, la mugre en la cocina, las varices, las deudas que navegan por la red como meteoritos. ¿Sin empleo somos poca cosa?

La crisis económica se agudiza cada día con la misma intensidad con que crece el número de contagiados y muertos. Son tantas las estadísticas, de salud pública, de cierre de empresas, de consumo de fármacos, de ventiladores, que es fácil confundirlas. Lo único claro es que el índice de capitalización de la bolsa mortuoria, que mide el comportamiento de la vida en las veinte principales ciudades, cada día cierra al alza. 
[ 186 ] Ante la crisis del capitalismo pandémico, supimos que es igual de valioso el empleado de una panadería que el de una multinacional. Ambos se valen de su salario para consumir. Si no se consume, se rompe la cadena productiva; si no salimos de casa todo se contrae. Si no hay salario no hay cómo hacerse a la mercancía. Y si esta deja de adquirirse, no hay plusvalía ni aura baudeleriana. Marx y Engels pensaron en esa serie para entender el modo de producción de la era industrial y convirtieron esa verdad en un derrotero político. A su manera, El capital de Marx prefigura el manifiesto del «Unabomber» Ted Kaczynski, La sociedad industrial y su futuro.

No es solo el fantasma de los brazos caídos el que ronda. Más bien, ahora que el mundo se detiene y aceptamos guardarnos por físico miedo, sin saber lo que pasa más allá de las Unidades de Cuidados Intensivos, otro fantasma recorre el mundo: el del totalitarismo. Sabe actuar y es silencioso. Al comienzo no produce pánico, porque impone con suavidad el orden, la disciplina, la asepsia. Después se desboca y se inclina hacia los extremos. Entiende, como Orwell y K. Dick, que eso de la conducta humana deviene programable. 


\section{Preguntas de oficio}

Para Adriana Villegas

¿Cómo nace un escritor? Suele ser una pregunta que se le hace a los escritores, en especial a aquellos con alguna notoriedad en el mercado de los libros o en el rumor vanidoso de las ferias culturales. Cualquiera sea la réplica, su alcance dependerá del grado de sofisticación de quien, ante la encuesta, perfecciona su memoria, se retrotrae, vincula su destino a un hecho histórico, añade un cuadro afectivo y señala un origen: hacerse mayor de edad en el silencio de las libretas de apuntes, esquivando el conflicto familiar (Capote); el regreso al lugar de la infancia, de la mano de la madre (García Márquez); la rutina de un hombre que espera paciente el ciclo de lavado de ropa en el laundry mientras decide 


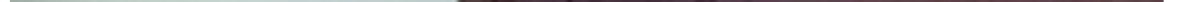


que al haberse convertido muy joven en un padre responsable y [ 189 ] fértil, lo suyo tendrá que ser el cuento breve (Carver).

¿Cómo se sostiene en la cadena económica un escritor? Con dificultades, sin duda. Porque si bien el suyo es un oficio en el que se acumulan horas de trabajo, repartidas entre el tiempo de la escritura, el tiempo de la lectura y el de las relaciones sociales, hay que sumarlo a la larga lista de los oficios informales. Con un agravante paradójico: el oficio de escritor se amarra al ocio, al tiempo libre, al ejercicio intelectual; en fin, a la experiencia de la vida burguesa. En las estadísticas de la economía naranja la mayoría de escritores terminan por convertirse en pobres vergonzantes. Está bien, a veces reciben un premio, regalías por la venta de un libro, el anticipo por la adaptación de una obra suya a otros formatos. Pero son excepciones a la regla, son dineros atrasados, pequeños balotos que no eliminan la incertidumbre del día siguiente. Lo común es otra cosa: la espera inútil por el best seller, la ilusión desvanecida por hacerse a un nombre, la falta de lectores, el vacío o la frivolidad.

¿Alguien echa de menos a un escritor en este absurdo tiempo detenido? Salvo en las centrales de riesgo, su número de cédula no aparece en las prioridades de las medidas sanitarias decretadas 
[ 190 ] por entes gubernamentales. Cuando los gremios y las empresas piden desesperados que flexibilicen las medidas de seguridad para que los trabajadores retornen a sus labores, nadie está pensando en el escritor ni en el valor de su fuerza de trabajo. A nadie, por lo menos, se le ha ocurrido decir que lo conveniente para aplanar el pico de la pandemia es que los escritores no salgan de casa. Existe la amenaza, el miedo, el control, el gel, el termómetro, el tapabocas; pero el escritor no existe ni genera un hashtag solidario.

¿Es interesante la vida de un escritor? Depende de lo que se entienda por interesante en una sociedad mediática, alimentada por el rumor y la maledicencia. Para serlo, el escritor debe esforzarse, dejarse llevar por su instinto antisocial y explorar unas formas atractivas a los grupos: el insulto, la pelea frontal, el desprestigio, el ataque a sus vecinos, divorciarse de su prima a los ochenta años porque llegó el amor en el cuerpo de una señora diva. En nuestro medio, valga decir, no abundan los escritores interesantes. Abundan los presumidos, los egópatas, los resentidos. Pero eso no necesariamente los torna interesantes. Para llegar a ser interesante en una sociedad pacata y doble, inspirada en la queja, el escritor debe esforzarse demasiado para superar, aunque sea por momentos, las noticias diarias de la corrupción, 
de la doble vida, de la doble militancia y la medianía de una socie- [ 191 ] dad melodramática del Yo me llamo.

¿Es aburrida la vida de un escritor? Tengo la convicción de que esta pregunta está ligada, hasta la muerte misma del autor, a la pregunta anterior. Pero dejemos que sean los propios escritores quienes lo digan:

Es verdad que, para un tipo como yo, estos días de encierro son más llevaderos que para el común de los mortales: al fin y al cabo, la vida cotidiana de un escritor es una vida de encierro, dedicada básicamente a escribir, leer y pensar en las musarañas (Cercas).

Con lo cual se colige que ya en el hábito del escritor, en su habitación propia, convive el patógeno del tedio.

Un escritor tiene un fuerte entrenamiento para la soledad y el silencio. La gente cree que la literatura tiene mucho glamour. Sí. A ratos cortos, muy breves. Momentos de glamour. Pero el 99\% del asunto es encerrarse durante horas y horas cada día en un espacio de silencio y soledad para poder escribir. Aislado (Pedro Juan Gutiérrez).

Con lo cual se entiende que solo el $1 \%$ de los escritores en cuarentena autoinfligida, conoce la felicidad. 
[ 192 ] ¿Cómo muere un escritor? Quizá sea la pregunta más lapidaria. Observará el lector ideal que el escritor se hace inmortal en su obra. Pero la inmortalidad es selectiva. Priman las termitas, los ácaros coronavíricos, los comejenes, las aguas desbordadas que inundan las bibliotecas públicas, el papel que se deslíe, el ordenador que un día se apaga. Solo la muerte es democrática. Dirá el lector plagiario que todo escritor es el olvido que seremos. Tal vez un lector intermedio juzgue que el escritor muere poco a poco, en cada una de sus obras. En las palabras, en lo que imagina con ellas, está escrita su derrota, su no ser. En la página necrológica, viral por un día, se condensará su historia, su solapa, su retirada. 


\section{El culo}

Para Edwin Vargas Bonilla

Tuvo que llegar el tiempo conspirativo de la pandemia para que yo adquiriera una nueva conciencia y no propiamente ambiental ni de género. Es algo más básico y ergonómico, y surge de una pregunta que en mi caso es nueva: ¿cuánto tiempo de nuestras vidas permanecemos sentados? A fuerza de hacerlo todos los días y de combinar esa postura con mover la cabeza, frotarse los ojos, acostarse, caminar, comer; el hecho de estar sentados, de pensar en lo que esto implica, suele pasar inadvertido.

Ahora que asumo la mayor parte de mis obligaciones laborales frente a la pantalla del computador, que el círculo de amigos puede desaparecer con un simple clic y el de enemigos imaginarios puede ir en aumento en Facebook, el pasado lunes en la mañana 


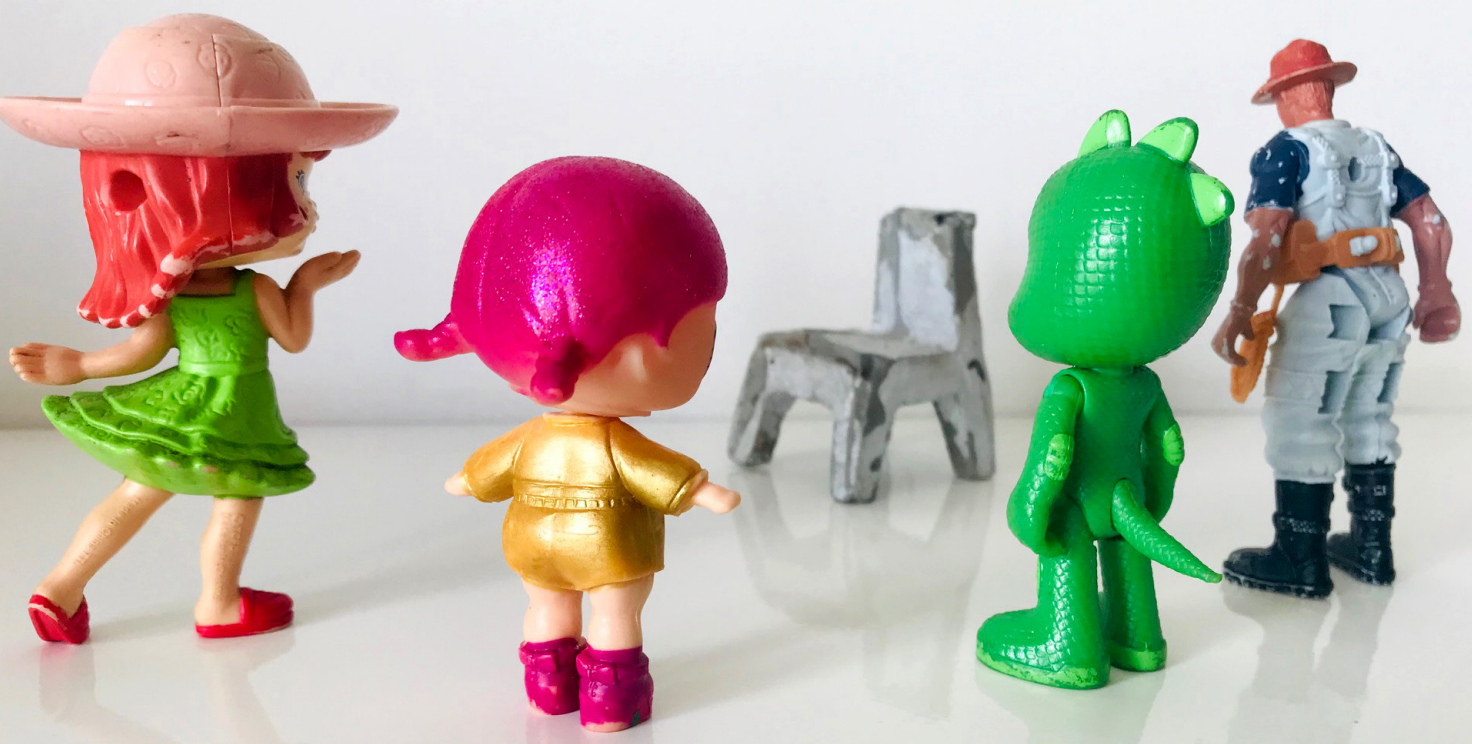


me sucedió algo extraordinario: casi por descuido, por intolerante frente a un emoticón monstruoso que alguien me envió al Whatsapp, desvié la mirada hacia mi propio cuerpo, observé mis manos arrugadas por el alcohol, mis pies con uñas partidas, mis rodillas peludas, mi estómago en aumento y descubrí algo que me tiene fascinado: tengo culo, estoy agradecido de saberlo allí, de palparlo, de comprobar que, en estricto sentido metafórico, es «tan blando por fuera, que se diría todo de algodón, que no lleva huesos».

Debieron sumarse muchos abriles en mi vida de profesor para declararme orgulloso de su forma y su funcionalidad; de la manera como atiende, silencioso, a una compleja red nerviosa de huesos, articulaciones y músculos.

El culo es, en su realidad trasera, un héroe anónimo. No apaga incendios, no atiende infectados en las Unidades de Cuidados Intensivos, no da la vida en campos de batalla, pero sí nos permite, en su discreta disposición, acomodarnos, sentarnos, instalar el cuerpo de un modo adecuado para pensar, para mirar hacia el horizonte, para hablarle a una cámara y para imaginar qué nuevas aventuras habrán vivido las familias del Fiscal y el Contralor en la desierta isla de San Andrés. ¿Habrán ido a Providencia? Porque 
[ 196 ] solo sentado puede uno imaginar este tipo de aventuras, propias de La isla de la fantasía.

Me dirán que lo de su anonimato no es cierto, que el culo se exhibe con morbosidad en los medios, que define tendencias de moda, que existe un culto a su personalidad, en especial, por nuestra cultura mafiosa; de ahí que sea sometido a peligrosas cirugías plásticas para agrandarlo con biopolímeros y hacerlo más atractivo en el intercambio sexual, a menudo prepagado. Me dirán que el culo está en el centro de la libido y de nuestras más selectas obsesiones eróticas. No puedo refutar ese cuadro de costumbres; solo que el culo al que me refiero, del que me ocupo mientras escribo sentado, es el natural, el más cercano a «Platero y yo», el que está ahí, imponiendo su carácter inclusivo. Con él llegamos al mundo y ocurre la primera epifanía: nuestras madres angelicales, con amorosa emoción, le untan Crema Cero, lo preparan para la pantomima de la infancia. Lo protegen de sarpullidos y picazones, mientras una tía melosa, más angelical aún, cierra la pureza de la escena con este poema de cuna: «Mírenlo, qué belleza, se parece al culito del Niño Dios».

Mi gran desencanto de adulto inquieto, inicia cuando consulto en el diccionario la definición de culo: «Conjunto de las dos 
nalgas». No hay derecho que una institución tan seria, tan antigua y barroca como la RAE despache el asunto de este modo tan pudoroso, con un binomio elemental. ¿Y qué es una nalga? Bueno, ahí sí se amplía el contenido y se da paso a la corrección política: «Cada una de las dos porciones carnosas y redondeadas situadas entre el final de la columna vertebral y el comienzo de los muslos». Estarán de acuerdo conmigo en que hablar de porciones carnosas nos lanza al mundo de las vacas. Por eso no me sorprende que la RAE recoja el significado de nalga en Argentina: «Corte del cuarto trasero de los vacunos, de la parte interna del muslo». Con lo cual redondeamos, a quienes somos carnívoros, un asunto de gustos culinarios - léase con terror esa palabra- caros a la antropofagia.

Sin tetas no hay paraíso, lo supo el filósofo pandillero Gustavo Bolívar. Pues sin culo no hay teletrabajo, lo sabemos a causa del confinamiento. Con todo y esta certeza, considero que los colombianos no hemos sabido darle a esta porción de nuestro cuerpo el lugar que le corresponde, como sí lo tiene en los cortes de las famas o carnicerías. Por eso es común escuchar esta expresión en nuestro medio vulgar: «Me importa un culo». Una de dos: quien la enuncia tiene nexos con la aduana de los Ambuila y se trata de una importación ilegal de tráfico de órganos, o se trata de una 
[ 198 ] expresión de menosprecio y, desde luego, del más profundo desconocimento orgánico. Ni una ni otra: ni los culos se importan como se importa un Ferrari ni importan poco. Acomódese, disfrute ese placer de estar sentado sobre un cojín mullido, nada artificial y haga lo que le convenga.

El culo es el centro más cómodo de nuestro cuerpo. No es el cerebro, que es elitista y acostumbra dar órdenes. Tampoco es el estómago, que nos induce al exceso. El culo, en cambio, es prudente y si nadie te lo mira, no existe, porque ya sabemos que «lo esencial es invisible a los ojos», como lo aprendió el alquimista Coelho en El principito. En su autonomía solo da bienestar y si le tocara dar órdenes diría: «iSiéntate!». O como enseñan los españoles sabios en tono imperativo y cervantino: «Pon tu culo ahí». 


\section{El placer de leer}

Para Juan Miguel Álvarez

Adheridas a las ondulaciones del Hudson, bellas postales de la ciudad de hierro y hormigón son arrojadas a las aguas fluviales como hologramas de una cartografía cara a la elástica red del Hombre Araña. Anida en los aleros del Bovery la soledad de una gaviota extraviada en primavera, cuando intentaba superar la aguja art déco del Empire State. Dos gatas abisinias se pelean un mendrugo de pan de centeno en Fulton Street, mientras un latino, curtido en los sudores del part-time, mira pasar una limousine blanca y evoca la belleza otoñal y lejana de Sharon Stone. Los parques de Manhattan concentran el brillo de la luz en el verano. Una chica gótica bordea la fuente de agua y refleja en el metal 


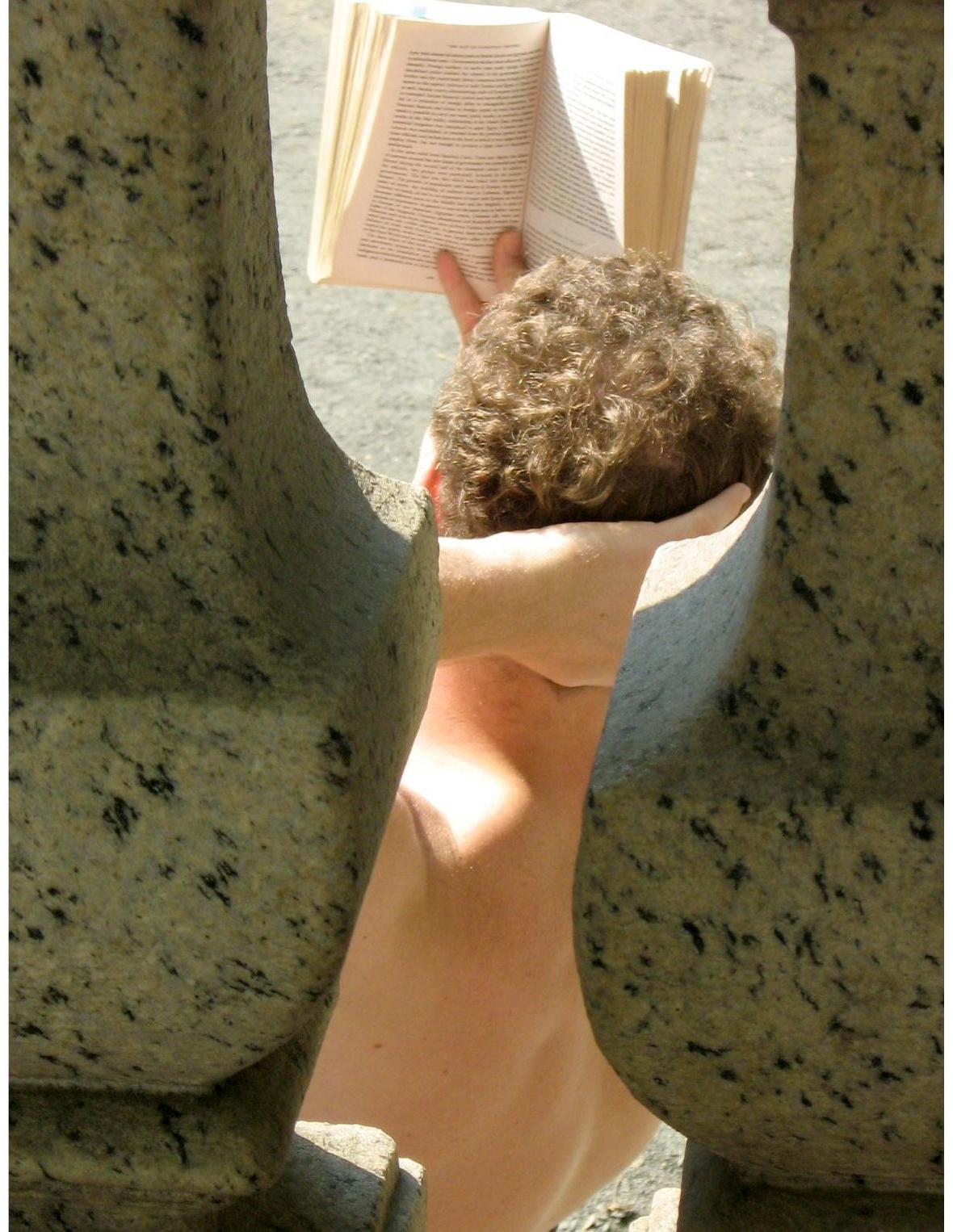


de sus piercings la silueta de un aviso que señala la ruta hacia la Zona Cero. Una anciana de arrugas húngaras se deja llevar por un cenizo perro labrador que olisquea las huellas más recientes dejadas por un french poodle. El cuerpo encorvado y la palidez de ese rostro que tal vez lloró la muerte de James Dean, me hacen temer que este sea su último paseo. Vive en desaliento, el perro lo sabe e impone un ritmo tranquilo que le permita llegar de nuevo a la buhardilla de la calle 34 . Una pareja de enamorados rastas se mete mano en una banca que fue, hasta hace poco, la cama de un homeless, indiferente a la falsa amabilidad de los yuppies, ahora que descienden de los rascacielos en busca de un helado y una ensalada de vegetales. Sobre el prado y en ropa corta de playa, mujeres maduras y chicos rubios se entregan a una actividad silenciosa y ritual: están leyendo y pareciera que no hay nada más importante para ellos que estar leyendo.

¿Qué leen?, me pregunto. ¿A qué lugar del mundo serían transportados? ¿Qué trama arroja sentido a la existencia individual? Logro acercarme, sigiloso, a un chico que resume en su piel la ardiente arena de las playas de Long Island. El intruso no existe para él; solo el mundo que reside entre las páginas; solo ese imperceptible batir de alas, entre el ojo y la hoja, entre el sosiego 
[ 202 ] corporal y el fino aroma que expelen las lisas fibras vegetales. Hay una alegre expectación en su mirada, una serena actitud en su cuerpo ágil. Una veta de sol toca la delgada superficie del libro abierto y el arte sucede en esa postal que pronto será noticia en las ondulaciones del Hudson River. Entre los ojos y la superficie de la celulosa expuesta al día, el misterio, el susurro gráfico de un mensaje directo, sin terceros.

La ciudad guarda prudencia en los contornos del parque, se contiene, eterniza el momento con su rumor de voces inmigrantes y esa lluvia eterna, de ruidos, extendida en las encrucijadas palpitantes. El juego de luces en los semáforos impone a la ciudad un ritmo lento, detiene por minutos el impulso cotidiano de un mapa en conmoción, a punto de estallar en sus arterias de túneles y redes ferroviarias. Así, el ritmo lento, el goce inolvidable sobre la dermis del prado, el libro expuesto en otra página, como la luz que autoriza en Chelsea Park tomar una ruta alterna, rumbo a los antiguos muelles que vieron descender familias irlandesas de los barcos.

Leer es un acto solitario, igual que caminar. También es un placer, como caminar una aventura placentera. Para llegar hasta allí, a la alameda de Tompkins Square y detener de algún modo el 
presente luminoso de esa cartografía rocosa que el Hudson atra[ 203 ] pa en sus aguas migratorias, nuestros lectores debieron cruzar calles, avenidas, una plataforma levadiza, subir las escaleras del subte en Penn Station o atravesar en bicicleta la herrumbre de un puente que nos arroja o nos trae de vuelta al vecindario de Brooklyn. Nuestros lectores han cruzado las calles y avenidas donde abundan los psicópatas de Auster, los sastres de Talesse, el elegante, los ebrios de Carver, las divas histéricas de Capote y los fantasmas de Mailer. Más allá de las pasarelas colgantes, un cielo azul registra, impávido, cómo las estructuras de metal y vidrio se aproximan a sus cristales de hielo.

Uno de ellos, acaso el más joven de los lectores, echó de menos la brisa refrescante de las diez en los senderos que trocan Central Park en territorio de duendes. La más adusta de las lectoras se dejó envolver por la mezcla de olores callejeros que impele los sentidos y se dijo que más tarde compraría gambas, cuencos de arroz y un poco de jengibre en Chinatown. Ambos habrían coincidido al cortar la muchedumbre de la calle doce, a la altura del 828 de Broadway, justo en la acera de Strand Books. Ambos, tal vez, se miraron y detallaron de soslayo lo que el otro llevaba entre sus manos. Desconocían que el destino los haría próximos y que la 
[ 204 ] acción de leer y dejarse transportar a la realidad otra de sus libros, entraña una señal feliz para los bohemios del Soho. Algo habrá cambiado desde entonces en sus vidas: para ella, en la página 53; para él, en el renglón que se parte en la página 122. Algo habrá cambiado para siempre en la Isla de las colinas pues, el azar y acaso una secreta confluencia de los astros que brillarán más tarde en el cielo de New Jersey, los hará llegar, sin aliento, a una página en blanco al dar las tres la tarde en las campanas de St. Patrick.

Rumbo a la alameda y excitados frente a la belleza densa y transpirante de julio, los lectores entregan a la ciudad sus deseos más recónditos. Los libros absorben el calor del mediodía y permiten en sus lomos deslizar un misterio, el contenido reservado de una historia. Fuera de las vitrinas de exhibición la vida en ellos reclama el brillo veraniego. La ciudad habita entre los libros, como el deseo, como el silencio de un lector entregado a la música de una frase dicha en susurro para él. La ciudad se confunde con el libro y, a partir de lo confuso, la ciudad se lee en el paso atento del transeúnte solitario, radiante con la imagen de un libro a punto de estallar en sus entrañas: «Como un salmón que salta desde la noche, así es el alba de Manhattan en los últimos días de verano, así es este casco de ciudad que sabe a sed». Así el 
libro, la irrepetible felicidad de un lector agradecido en el corazón [ 205 ] agitado de una urbe de neón y bronce y hierro. Desde una azotea de East Village, el tímido Peter Parker vigila satisfecho su roca más preciada. Extiende su red arácnida hasta los secos árboles de Tompkins Square. No quiere incomodar, solo intenta saber qué leen las mujeres maduras y los chicos rubios del verano, ahora que la desnuda pasión de Mary Jane lo espera, bajo la luna caliente de una olvidada estación de Harlem. 



\section{Vidas inusuales \\ La casa de los hermanos Collyer}

Mientras la cifra de muertos crece al ritmo de la inquietud colectiva y la hidroxicoloroquina nubla el estado mental de gobernantes déspotas, Nueva York se aparece en los sueños. No es la ciudad de los rascacielos la que se impone en los hologramas desteñidos; más bien la que reclama una imagen colorida es la ciudad baja, cuyos vapores se disuelven al nivel de las aceras y de los pequeños parques. En uno de ellos, sobre las rocas de Manhattan, en el cruce de la 5 Avenida y la calle 128, al oeste del barrio Harlem, existe el parque enrejado de los hermanos Collyer. Aquí, el sueño de la historia nos obliga a detenernos.

En el parque de los hermanos Collyer crecen nueve árboles delgados que dan sombra a tres bancas de las que usan los home- 


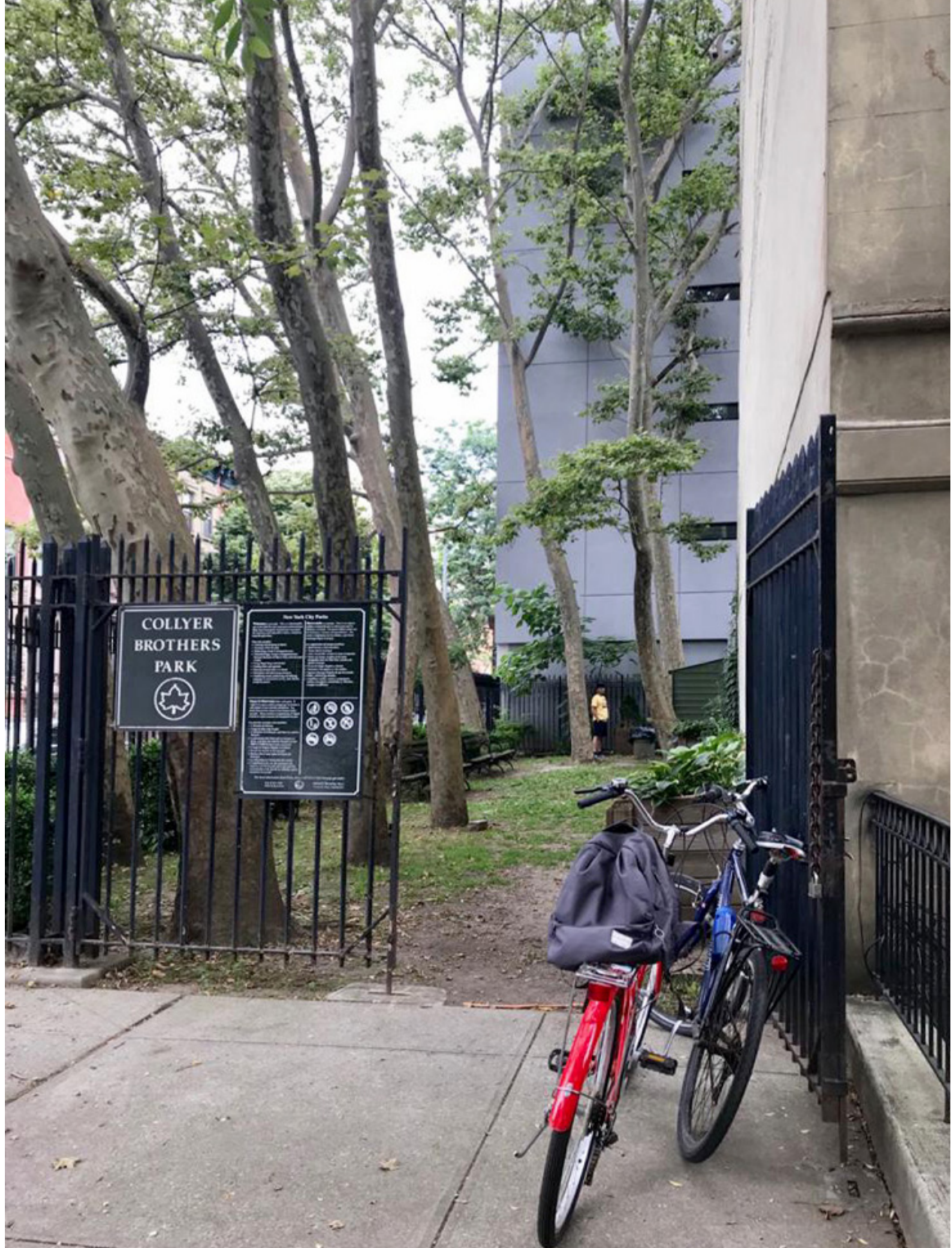


less para descansar y hacer la siesta en el horario permitido. Es el homenaje de la ciudad a Homer y Langley Collyer, un par de hermanos excéntricos que convirtieron su casa-mansión, ubicada justo en esa área del parque, en una especie de museo de las cosas inútiles, cuyo peso, de más de cien toneladas, obligó a derribar la casa, una vez sus residentes fueron encontrados muertos en su propio basural.

Hijos del médico Herman Collyer y Susie Gage Frost, una cantante de ópera, los hermanos Collyer se quedaron solos en su casa de Harlem porque, según la leyenda del vecindario, sus padres los abandonaron a su suerte. Se supo que el padre murió en 1923 y la madre en 1929 y que todo lo heredado empezó a hacer bulto en su casa de cuatro plantas. Desde entonces se sumieron en una relación hostil con la ciudad y empezaron a vivir de puertas para adentro, como «ermitaños acumuladores y maniáticos», según lo resume Edgar Lawrence Doctorow, el novelista que trasladó el mito de los Collyer a la ficción, en su novela Homer y Langley.

A finales de la década del veinte, los hermanos Collyer no volvieron a pagar los servicios públicos y la ciudad los desconectó. En realidad, ellos se habían desconectado mucho antes, cuando el vecindario se transformó en el traspatio de su casa. Homer, licen- 
[ 210 ] ciado en Derecho Marítimo y Langley, en Ingeniería Mecánica y Química, ambos de la vecina Universidad de Columbia, decidieron que podían vivir de espaldas a la urbe, confinados a su manera. La ciudad llegaba hasta ellos convertida en objetos, periódicos, libros, pianos, revistas y cuanta cosa se compra y vende en los templos capitalistas del consumo. Herederos de la era industrial, pensaron que podían autoabastecerse e intentaron crear su propia planta de energía con base en la batería de un Ford T que las autoridades locales hallaron en una de las salas de la mansión, como si se tratara de una escultura futurista.

En 1931, después de sufrir un derrame cerebral que le produjo una severa hemorragia, Homer Collyer quedó ciego. Se negaron a visitar hospitales con el argumento de que eran hijos de un médico y que además poseían en su biblioteca más de 15000 libros de medicina, suficiente literatura para arriesgarse en la interpretación del vasto universo de la enfermedad. Langley dedicó su vida a cuidarlo a base de recetas estrafalarias que incluía naranjas, cacahuates y pan integral. Seguro de que Homer en algún momento recuperaría la visión, Langley se puso en la tarea de coleccionar los periódicos de la ciudad para que su hermano se enterara luego de todo lo que había pasado mientras vivió en la oscuridad. 
Sus vidas épicas, y en especial la de Homer, fueron una versión neoyorquina del Poema de los dones de Borges, donde se alude a la historia griega de un rey que muere de sed y hambre entre «fuentes y jardines», mientras un lector fatiga «sin rumbo los confines de esta alta y honda biblioteca ciega».

El 24 de marzo de 1947, luego de recibir la llamada de un vecino que alertó sobre un posible cadáver, la casa-mansión de los hermanos Collyer fue allanada por policías y bomberos. En lugar de uno encontraron dos cuerpos sepultados por los desechos. Fue como si llegaran a un basural: las cuatro plantas de la casa estaban atestadas de toda clase de objetos y basuras. A falta de herederos, le recuerda Doctorow al novelista Juan Gabriel Vásquez, «la ciudad se apoderó de la casa». Ese inmueble, ubicado al norte de Central Park y muy cerca del campus de Columbia, se convirtió de pronto en un símbolo de los tiempos de entreguerras, como si a partir de allí el sueño americano descansara en la relación que los individuos instauran con los objetos y, en especial, con los objetos que se adquieren compulsivamente.

Cuando Enrique Vila-Matas dejó Nueva York para trasladarse a Providence, el poblado donde nació Lovecraft, según lo evoca en el fragmento 29 de París no acaba nunca, supo, después de soñar 
[212 ] con imágenes de dos ciudades, que una noche no era suficiente para presentir las pulsiones de vida detrás de las fachadas y dentro de los rascacielos de hierro y vidrio. «Nueva York es un deseo que viene de lejos», dice. Porque la ciudad contiene su propia memoria y se interpone en los sueños; crea conexiones entre las realidades más insólitas, nos invade.

Al pensar en la vida excéntrica de los hermanos Collyer, en esa obsesión suya por acumular basura y vivir entre ella, en esa irrealidad que puede anidar en un nicho próximo a la ceguera y la locura, pensé de súbito en otro excéntrico: Joe Gould, el licenciado de Harvard, que arribó en 1917 a Nueva York con una noble misión: escribir la más extensa historia sobre la vida en aquella ciudad, su famosa Historia oral de nuestro tiempo. A pesar de que el uno recorría como vagabundo las calles de Greenwich Village y los otros vivían en una inmensa casa de Harlem, como aristócratas en desgracia, es posible juntar los tres sueños, ya no en el patio de la infancia de Vila-Matas, sino en el parquecito de los Hermanos Collyer. Al fin y al cabo, no debería sorprendernos que, en un rapto de ebriedad, Joe Gould fuera hasta ese lugar a descansar como un noble homeless para pergeñar, en medio de su resaca, una página más de su voluminosa Historia oral de nuestro tiempo. 


\section{El mal gusto}

Si algo ha descubierto el teatrino de la pandemia es el mal gusto que se impone en la vida privada. El mal gusto está en los detalles - el color de la pared, un techo caído, una cortina granate-, en las pequeñas cosas - una artesanía de San Agustín rota y recién pegada con colbón, un llavero de Sanandresito- y es tan fiel como el mal aliento.

Tras bambalinas, lo vemos en tiempo real cada vez que abrimos Zoom, Meet, Webex y un etcétera de plataformas que han señalado la ruta monótona de unas vidas conectadas a un link, nuestro respirador orwelliano: una versión parlache de Matrix, sin teléfono de disco, sin agente Smith, sin aventura.

Sus protagonistas no lo pueden evadir, porque el mal gusto habita allí, entre nosotros, como un paisaje natural, como un 


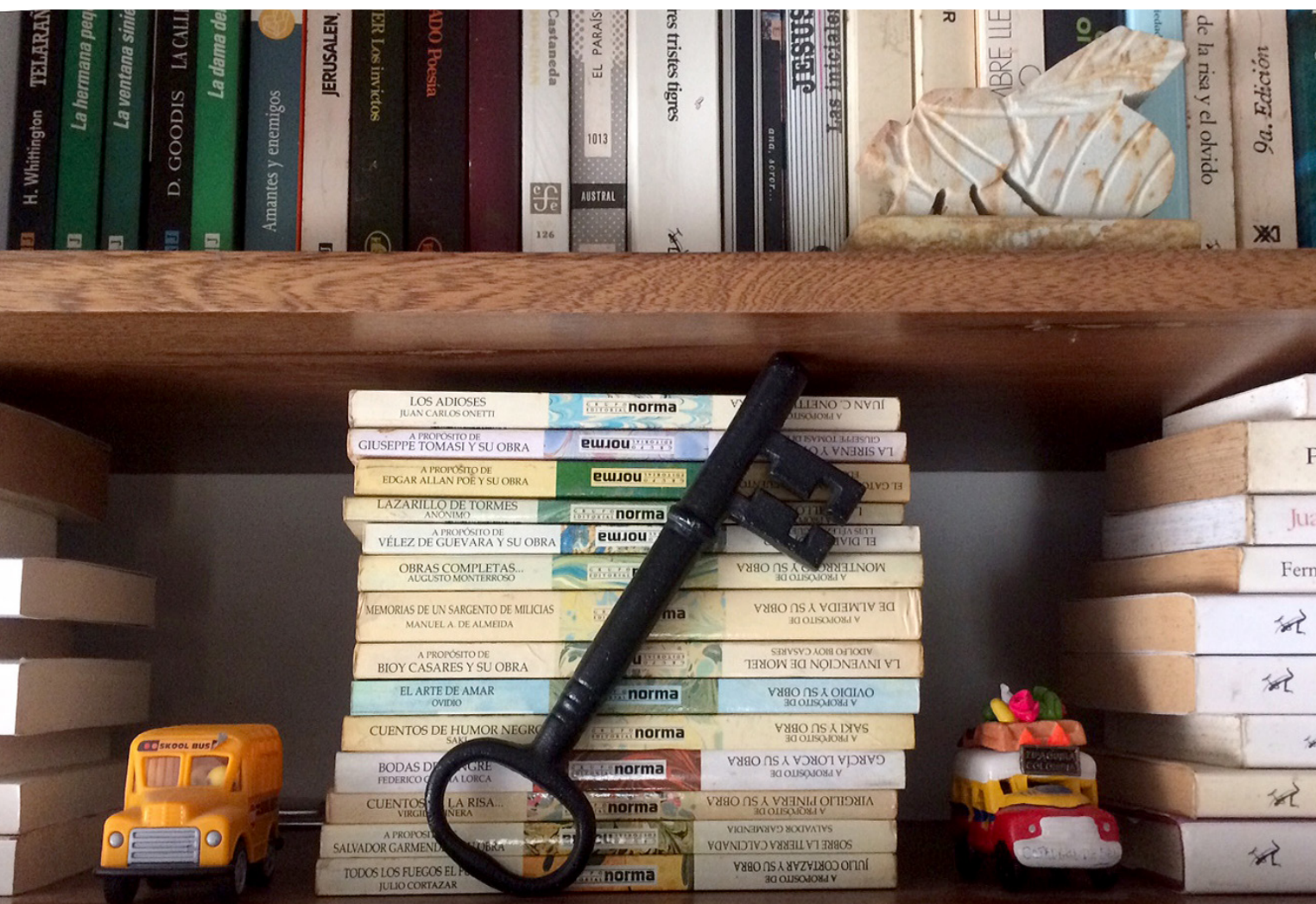


remordimiento, como una pared con humedades antiguas. Como un gato que rasguña el sofá de la sala y orina en la matera. Como un corrupto que sube de peso y exuda en las audiencias. Se enquista en la rutina y con el tiempo se aglomera y define, con agresivo interés, rasgos de nuestra personalidad, para solaz de los discípulos de Freud que sabrán empaquetar con remoquetes lo que en verdad somos: obsesivos compulsivos, megalómanos, bipolares, acumuladores de baratijas.

El mal gusto tiene la consistencia de las telarañas y la adherencia de los ácaros. Crea su propia naturaleza salvaje, ahora que una nueva enfermedad coronavírica grita con su megáfono dictatorial por calles desoladas: «iQuédate en casa y lávate las manos con jabón de coco cada veinte minutos!».

Obedientes frente al dictamen de la distancia social y condenados a exhibir encuadres del mundo de la casa por la contingencia del teletrabajo, nos convertimos en youtubers, quién lo creyera, después de viejos. Sin ningún atractivo físico, sin ninguna habi- 
[216 ] lidad oratoria, nos toca improvisar, armar un escenario, volver a los domingos de Animalandia, en sesiones espiritistas con gente conectada y sin rostro: «Gregorio, ¿aún estás ahí? Di algo». Seleccionar un buen escenario implicaría contratar a Silvia Tcherassi, a Hermanos a la obra, a No te lo pongas. Pero ya es tarde y no hay recursos, solo impuestos y decretos a causa de la emergencia sanitaria.

En esta intimidad pública, las bibliotecas personales aparecen como una fachada; son hologramas del deseo. Quizá, debajo de las capas de polvo, se esconde un mal lector. Si nos pusiéramos a discriminar el tipo de libros que tienen los youtubers emergentes podríamos decir algunas cosas. Las bibliotecas de las presentadoras de televisión contienen temas de moda: el taichi, los nuevos platos de MasterChef. Las de los intelectuales de izquierda son deplorables: es como si aún la antigua Unión Soviética les siguiera enviando las obras completas, sin costo, de Vladimir Ilich Ulyanov, «Lenin». Las bibliotecas de los ministros son lamentables: libros de encuestas y estadísticas, y una que otra biografía sobre un vitalicio y anacrónico mandatario cargado de tigre. Las de los profesores emanan el olor a guardado de la naftalina: el Manual de gramática española de Rafael Seco, el Diccionario panhispánico 
de dudas y los libros feos y descuadernados, impresos por la oveja [ 217 ] negra que tenían de gerente.

Para nadie es un secreto que el mal gusto empieza con las alocuciones del actual presidente, emitidas desde el palacio de Nariño. ¿Alguien puede explicarme qué vemos detrás del cuerpo del mandatario cada vez que le da por hablar como un gerente de hospital subsidiado, a eso de las seis, cuando ya no hay esperanzas de vida? Yo logro ver el pedazo de algo que parece ser el lienzo antiguo de una pintura triste, mañé. No faltará el crítico de arte que me llame la atención y me diga que ese pedazo que vemos allí hace parte de una pintura que recoge, pongamos por caso, el instante en que el virrey español Sebastián de Eslava medita en la manera en que defenderá la ciudad amurallada del ataque de los ingleses. Lo siento, yo solo logro ver un emplasto, unas recinas que envejecen mal. Lo que sí se ve bien, y siempre en el mismo lugar, es el frasco de gel con pitillo naranja que, al parecer, el presidente nunca usa. Sabemos que, en las obras teatrales, en la puesta en escena, domina lo falso, incluyendo la escenografía, sobre todo en tiempos de la economía naranja y podrida.

El mal gusto sabe cómo presentarse. Eso sí, opta, vanidoso, por colgarse en las paredes a modo de trípticos impresionistas. 
[ 218 ] Tiene forma de esculturas compradas a crédito en Falabella, de tapetes persas en promoción, de porcelonas kitsch y bisuterías adquiridas en las ferias artesanales de neohippies ambientalistas. Tiene, además, y no es poca cosa, la forma de los rostros vacilantes, capturados en un primerísimo gran plano, donde es imposible escapar a los detalles: la abundancia de pelos en la nariz; la falta de dientes sin leche, las orejas grandes, la caspa, el estrabismo infantil, la calva grasosa, el tic nervioso. En fin, el ojo brillante de la cámara, Google Calendar, captura una parte de nuestra realidad íntima, quebradiza; y me aflige decir esto: al tornarse pública, esa realidad es inmodificable. 


\section{La sombra del Poder}

Sin rostro declarado, el Poder se torna silencioso mientras ejerce dominio sobre las cosas y las manipula. Parece volátil y sin embargo soportamos su peso, su respiración. En su gramática, se escriben los decretos y las normas; también los incisos, la letra menuda, el parágrafo que puede interpretarse de acuerdo con los intereses de los grupos.

En su gramática, la realidad cobra un sentido que solemos aceptar sin ninguna otra alternativa, porque en lo imperativo no hay espacio para la semántica, mucho menos para la interpretación por fuera de su radio. Ejerce un control y, en la serenidad de algunos días, creemos que si existe, es porque la sociedad lo necesita para evitar el caos y detener lo inestable. 


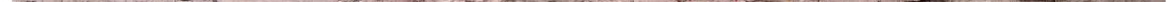


De pronto, cuando menos lo esperamos, el Poder se torna ruidoso, anima el escándalo, nutre la indignación efímera, en especial cuando desvela lo corrupto de sus formas. Algo de su rostro poco diáfano cobra identidad a la luz del día y esa misma luz se encarga de lucir lo que se escondía detrás del silencio y del rostro indefinido. Pero todo pasa y todo queda.

Perplejos e inermes y sin ninguna otra opción, vemos desde lejos cómo ese Poder extiende sus tentáculos, cómo, sin miramientos, invade la privacidad, desprestigia, fabrica pruebas a su medida, hace de la realidad un holograma de conveniencias e impulsa el fanatismo de sus adláteres. Este es el tipo de Poder gamonal que ahora se niega a guardar silencio, a cambiar de manos. Insiste en permanecer en cuerpo ajeno, sin renunciar al estado vulgar del diminutivo. Lo suyo es interponerse, retrasar, filtrar, chuzar. No hay nada más definido, esta vez, que lo perverso de su rostro sexagenario, con paisaje ganadero y caballar de fondo.

Miremos hacia atrás y hablemos en presente: para blindarse, el Poder selecciona unos voceros, nombra figuras de marioneta en los más altos cargos; expande, a través de ellos, un discurso programático y reitera en los medios frases sonoras que invocan lo patriótico, lo nacional, lo identitario. 
[222 ] De tanto aparecer en los medios, lo programático debilita la verdad e impone un nuevo orden, un tejido de rumores, una estela de sospechas y desconfianzas. El tema ético suele ser un decorado y los asuntos morales terminan por convertirse en preceptos religiosos. Ambos confluyen en capricho. Para entonces, se ha propagado una ideología al servicio del buró político. Para entonces, la verdad maquillada deriva en gritos, regaños e insultos que se propagan por las redes.

Una vez blindado, el poderoso selecciona a quienes les delega el trabajo sucio, acaso porque, heroicos, sus alfiles están dispuestos a sacrificar su libertad en nombre del líder burócrata. Da cuerpo a una de sus muchas perversidades: se rodea de seres sumisos, sin criterio propio, sin escrúpulos.

El Poder erige sus bases sobre el secreto y el ocultamiento. He ahí su fortaleza y debilidad, su paradoja. Porque lo oculto y lo secreto tienden a emerger y ni siquiera el implicado puede frenar su impulso y sus efectos. Wikileaks lo entendió en el corazón de Europa y por eso extiende la certeza a través de la insondable red a modo de archivos que perdieron, de súbito, su carácter confidencial, el valor de lo inescrutable. Recordemos el escándalo más reciente: la vida excéntrica de Jeffrey Epstein y sus amigos poderosos. 
Visible lo oculto, desvelado lo secreto, le queda al Poder otra arma sofisticada: la desinformación. En el ámbito militar, se traduce como teoría del rumor: ese complejo sistema de versiones que termina por instalar la ficción en la realidad. Desinformar entraña un nuevo lenguaje puntilloso o, por lo menos, el uso de un lenguaje de ataques y sobreentendidos.

El Poder se niega a callar, porque sabe que el silencio lo diluye, difumina su rostro; así que emplea Twitter para propagar el eco de su lenguaje escaso. Lo más perverso es que se engulle a sí mismo, como un uróboro, aunque luego muda y se traspasa a otros seres reptilianos. Después, decide afinar su retórica eufemística para maquillar su semblante y es como si algo en la historia se hubiera detenido para siempre.

Cuando alguien se aferra a él y no quiere soltarlo, el mismo Poder que ha construido lo destruye, lo desprestigia, lo hace a un lado. El poderoso sufre, toma agua de valeriana para moderar su resentimiento, se retuerce en sus haciendas y algo hay de justicia, para la mayoría silenciosa, en ese sufrimiento. 



\section{Desaparecer}

El diccionario es terrible en su realidad semántica. Desaparecer: «Ocultar, quitar de la vista con presteza. Dejar de existir». No es un acto de magia circense, tampoco una actividad lúdica, como si jugáramos a las escondidas, como si, al ocultarnos, pudiéramos decidir cuándo hacernos visibles. Desaparecer es un problema, una angustia familiar, una incógnita, un seguir siendo sin estar o un estar en otra parte, quién sabe bajo qué circunstancias. Si bien se deja de existir - al menos para un círculo familiar afectado-, se sigue existiendo de otro modo: en la ausencia, en la espera, en el dolor, en la incertidumbre, en la nada.

Desaparecer es un asunto ontológico, que toca la piel y los huesos, que los arruma en un dolor de casa, que los vulnera en el 


\section{SE BUSCA}

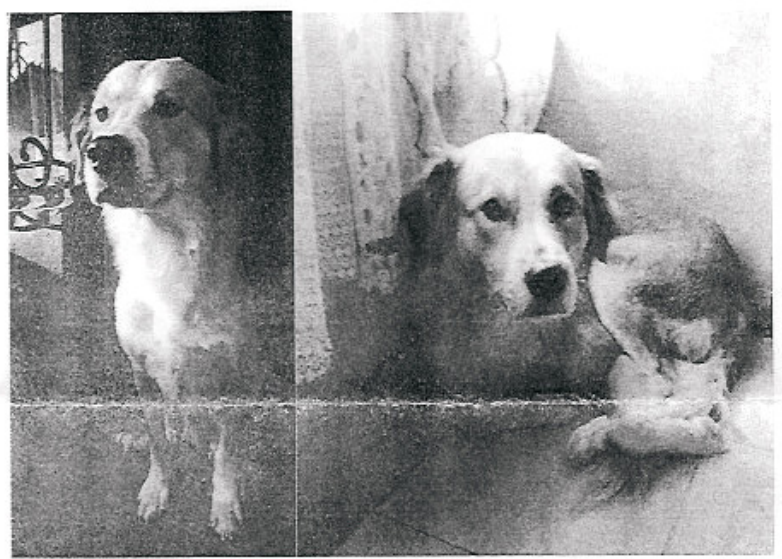

URGENTE... se perdió este perrito COJO hoy 12 de julio en la tarde por los lados de la Av. del rio (aunque puede estar en cualquier otro lugar). Responde al nombre de DOMBULDOR y su mayor característica es que anda en tres patas la otra esta coja. Estamos muy angustiados, cualquier información es valiosa. GRACIAS si lo ven: 3117626941 ó 3117761281 
recuerdo. Desaparecer es un dilema social, que se agrega a la política de un país anárquico y falsamente positivo como el nuestro.

En la ciudad los perros desaparecen, las niñas desaparecen, los viejos desaparecen, los militantes desaparecen. En fin, muchos se hacen fantasma y, como diría el poeta antes de doblar la esquina, con los desaparecidos podría construirse otro país de sombras, de seres no identificados, sin dolientes. Un país clandestino, paralelo. Es una práctica común, hay que admitirlo, eso de desaparecer. Como también hay que admitir que sucede con frecuencia, cerca de nosotros, a un lado de la vía, en lo recovecos de los barrios, en la Avenida del río, o en «cualquier otro lugar». Ahora le tocó el turno a Dombuldor, un perro cojo, que tiene la característica de andar en tres patas. ¿Cómo no verlo, cómo no llamarlo por su nombre? Su familia está angustiada y por eso deja unos números telefónicos en un cartel adherido a las paredes llenas de anuncios, como quien siembra una esperanza, como quien espera el milagro de una voz que les anuncie que Dombuldor está bien y que en poco menos de una hora, estará de vuelta en casa.

¿Cómo desaparece un perro cojo? ¿Cómo desaparece una niña de trece años que iba camino de la escuela? ¿Cómo desaparece el muchacho rockero que está convencido de que las multinacio- 
[ 228 ] nales se apropian de nuestros recursos y nos empobrecen más? Somos cuerpo, somos huesos, somos piel, somos dientes y vamos vestidos por el mundo. Existimos, tenemos un número de identificación. Por lo tanto, desparecer no es fácil, porque no somos aire, nos somos brisa, no somos luz. Somos personas, animales, tenemos solidez. Alguien debería dar respuesta a esas inquietudes. Alguien, una autoridad, debería aparecer, dar la cara, superar la mera cifra de las estadísticas y decretar que no es posible desaparecer, así no más, pues nadie debería ser quitado de la vista con presteza. Salvo que desaparecer sea un acto voluntario. Pero sucede que Dombuldor, la niña de trece años, el muchacho rockero han desaparecido de manera extraña y no propiamente por una convicción. Me esfumo, me hago aire, me hago miedo, me busco y escribo sobre las paredes de una ciudad indiferente, un número telefónico. Tengo la ilusión de que me llamen y que una voz dulce confirme, con presteza, mi existencia. Gracias si me ven. 


\section{Qué raro que me llame Rigo}

Estoy molesto, a pesar de mi condición de gato domesticado. Suelen pensar que los de mi especie, harto cautelosos, somos solo ternura y mimos, hasta el punto de que frente a las visitas estamos casi que obligados a ser amables y a observar a los demás con interesada deferencia. Entre las visitas no falta el erudito capaz de recitar poemas, cuentos y desideratas en los que solemos ser dulces protagonistas, o en el oscuro universo de Poe, terribles bestias que anuncian el insondable abismo de los bípedos perversos. Detesto la ficción por mentirosa y a los novelistas por antianimalistas. Me inclino por los testimonios. A ver, ¿alguno de ustedes ha leído La gran matanza de gatos del humano Robert Darnton? Hubo tiempos de venganzas y penurias. Mis antepasados han sufrido en abundancia, créanme. El nuestro no ha sido precisamente un mundo de porcelana. 


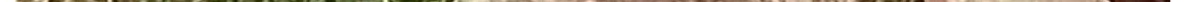


Nuestro orbe gatuno tiende a ser más complejo de lo que consideran nuestros dueños. Por ahí empieza mi molestia: que alguien se crea que nosotros somos de su propiedad. Nos rebajan a la condición material de un objeto. Conozco muchos de los míos que terminan por convertirse en esa pieza decorativa a la que bautizan con un nombre y a quien a menudo les consultan estupideces, como si eso de responder con palabras y pensamiento complejo fuese cosa nuestra. En estos días, durante un paseo solitario por una encrucijada leí en un poste este mensaje: «Busco a mi dueño. Favor llamar a este número. Se ofrece recompensa». Perderse es fácil, en especial por esa propensión nuestra a escaparnos en las noches a vivir aventuras felinas. De eso no hablaré acá, no es el tema. De lo que quiero hablar es de un fastidio que me aqueja por estos días. Tiene que ver con el nombre con que me bautizaron en casa de los Alzate. Observen mi distintivo, deletreen mi nombre. Así es, me llamo Rigo. Qué horror. Debe ser un nombre sacado de telenovela del medio día. Se me hace que fue tomado de La rosa de Guadalupe, ese drama en que, sin poder evitarlo, uno termina llorando y lamentando ser pereirano, dosquebradense o gato. ¿Y dónde queda mi pedigree, esa alcurnia que me enlaza con la histo- 
[ 232 ] ria de los felis silvestris de Oriente Medio? ¿Dónde los nombres con que la reina Isabel solía identificar a sus mascotas?

«Qué raro que te llames Rigo», me ronroneó Sofía Button, una bella singapura del barrio Los Alpes. «¿Rigo, hipocorístico de Rigoberto?», preguntó sabia, no sin extrañeza. «En efecto», solo se me ocurrió esta respuesta. La Button volteó cola, impetuosa y se fue para siempre por un antejardín de astromelias. Su extrañeza llevaba implícito un reclamo, un «perteneces a otro estrato». Llamarse Rigo es tan indebido y popular como llamarse Rigoberto. Supe en las noticias del mediodía que uno de los sujetos más peligrosos de Bogotá era conocido en los recovecos del hampa con el alias de Rigo. Que los cuadernos de don Rigoberto, que el ciclista chabacano Rigo Urán, que el peor asesino de la cárcel de Lecumberri en tiempos del preso Álvaro Mutis. En fin, no es sencillo cargar con eso peso nominal. Lástima que aún no existan notarías para gatos. Lo primero que haría sería cambiarme de nombre. Un nombre secreto, fino, borgiano. Pero de ese nombre hablaré otra tarde, en otro aleph. 
Este libro terminó de imprimirse en noviembre de 2020, en Gráficas Olímpica, Pereira. La edición estuvo al cuidado de su autor. 
Solo percibimos que, al caminar, al superar un obstáculo en la acera y al levantar la mirada hacia ninguna parte, sucede que observamos algo que jamás habíamos visto: el trazo rabioso de un grafiti en una loza de pedernal; la grieta con nervaduras en una fachada húmeda; el grosor del hollín en un semáforo intermitente; la forma provocadora en la que una mujer se reconoce, casi desnuda, en el reflejo de una vitrina. Te invade, sin embargo, la sospecha de que nada de lo que has visto es nuevo, que su materia onírica deviene tan familiar como tus tenis. Quizá en el fardo de tu memoria se hayan mezclado pedazos de imágenes en tono sepia, el fotograma de una película vista en un cine de barrio, la instantánea en colores tomada al azar un día después del sábado. ¿Será que el ojo piensa? Te cuestionas y una posible respuesta la encuentras cruzando la otra esquina, cuando te enteras que no estás solo, que otros caminan con una feliz insolencia parecida a la tuya; que apenas eres parte de una ciudad que te observa en el brillo de las cosas y te ofrece caminar y pensar al mismo tiempo.
Universidad Tecnológica de Pereira

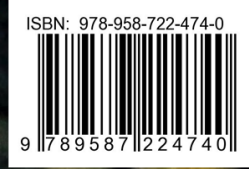

elSBN: $978-958-722-475-7$ 